\title{
Limnology of Big Lake, South-Central Alaska, 1983-84
}

United States

Geological

Survey

Water-Supply

Paper 2382

Prepared in cooperation with the Alaska Department of Natural Resources

Division of Geological and Geophysical Surveys
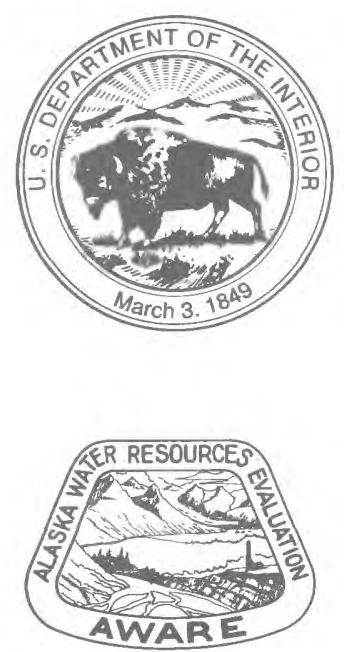


\section{SELECTED SERIES OF U.S. GEOLOGICAL SURVEY PUBLICATIONS}

\section{Perlodicals}

Earthquakes \& Volcanoes (issued bimonthly).

Preliminary Determination of Epicenters (issued monthly).

\section{Technical Books and Reports}

Professional Papers are mainly comprehensive scientific reports of wide and lasting interest and importance to professional scientists and engineers. Included are reports on the results of resource studies and of topographic, hydrologic, and geologic investigations. They also include collections of related papers addressing different aspects of a single scientific topic.

Bulletins contain significant data and interpretations that are of lasting scientific interest but are generally more limited in scope or geographic coverage than Professional Papers. They include the results of resource studies and of geologic and topographic investigations; as well as collections of short papers related to a specific topic.

Water-Supply Papers are comprehensive reports that present significant interpretive results of hydrologic investigations of wide interest to professional geologists, hydrologists, and engineers. The series covers investigations in all phases of hydrology, including hydrogeology, availability of water, quality of water, and use of water.

Cir'culars present administrative information or important scientific information of wide popular interest in a format designed for distribution at no cost to the public. Information is usually of short-term interest.

Water-Resources Investigations Reports are papers of an interpretive nature made available to the public outside the formal USGS publications series. Copies are reproduced on request unlike formal USGS publications, and they are also available for public inspection at depositories indicated in USGS catalogs.

Open-File Reports include unpublished manuscript reports, maps, and other material that are made available for public consultation at depositories. They are a nonpermanent form of publication that may be cited in other publications as sources of information.

\section{Maps}

Geologic Quadrangle Maps are multicolor geologic maps on topographic bases in 71/2-or 15 -minute quadrangle formats (scales mainly $1: 24,000$ or $1: 62,500$ ) showing bedrock, surficial, or engineering geology. Maps generally include brief texts; some maps include structure and columnar sections only.

Geophysical Investigations Maps are on topographic or planimetric bases at various scales; they show results of surveys using geophysical techniques, such as gravity, magnetic, seismic, or radioactivity, which reflect subsurface structures that are of economic or geologic significance. Many maps include correlations with the geology.

Miscellaneous Investigations Serles Maps are on planimetric or topographic bases of regular and irregular areas at various scales; they present a wide variety of format and subject matter. The series also includes 7 1/2-minute quadrangle photogeologic maps on planimetric bases which show geology as interpreted from aerial photographs. Series also includes maps of Mars and the Moon.
Coal Investigations Maps are geologic maps on topographic or planimetric bases at various scales showing bedrock or surficial geology, stratigraphy, and structural relations in certain coal-resource areas.

Oll and Gas Investigations Charts show stratigraphic information for certain oil and gas fields and other areas having petroleum potential.

Miscellaneous Field Studies Maps are multicolor or black-andwhite maps on topographic or planimetric bases on quadrangle or irregular areas at various scales. Pre-1971 maps show bedrock geology in relation to specific mining or mineral-deposit problems; post-1971 maps are primarily black-and-white maps on various subjects such as environmental studies or wilderness mineral investigations.

Hydrologic Investigations Atlases are multicolored or black-andwhite maps on topographic or planimetric bases presenting a wide range of geohydrologic data of both regular and irregular areas; principal scale is $1: 24,000$ and regional studies are at $1: 250,000$ scale or smaller.

\section{Cataiogs}

Permanent catalogs, as well as some others, giving comprehensive listings of U.S. Geological Survey publications are available under the conditions indicated below from the U.S. Geological Survey, Books and Open-File Reports Section, Federal Center, Box 25425, Denver, CO 80225. (See latest Price and Availability List.)

"Publications of the Geological Survey, 1879-1961" may be purchased by mail and over the counter in paperback book form and as a set of microfiche.

"Publications of the Geological Survey, 1962-1970" may be purchased by mail and over the counter in paperback book form and as a set of microfiche.

"Publications of the U.S. Geological Survey, 1971- 1981" may be purchased by mail and over the counter in paperback book form (two volumes, publications listing and index) and as a set of microfiche.

Supplements for $1982,1983,1984,1985,1986$, and for subsequent years since the last permanent catalog may be purchased by mail and over the counter in paperback book form.

State catalogs, "List of U.S. Geological Survey Geologic and Water-Supply Reports and Maps For (State)," may be purchased by mail and over the counter in paperback booklet form only.

"Price and Availability List of U.S. Geological Survey Publications," issued annually, is available free of charge in paperback booklet form only.

Selected copies of a monthly catalog "New Publications of the U.S. Geological Survey" available free of charge by mail or may be obtained over the counter in paperback booklet form only. Those wishing a free subscription to the monthly catalog "New Publications of the U.S. Geological Survey" should write to the U.S. Geological Survey, 582 National Center, Reston, VA 22092.

Note.--Prices of Government publications listed in older catalogs, announcements, and publications may be incorrect. Therefore, the prices charged may differ from the prices in catalogs, announcements, and publications. 


\section{Limnology of Big Lake, South-Central Alaska, 1983-84}

\section{By PAUL F. WOODS}

Prepared in cooperation with the Alaska Department of Natural Resources

Division of Geological and Geophysical Surveys 


\section{U.S. DEPARTMENT OF THE INTERIOR \\ MANUEL LUJAN, JR., Secretary}

\section{U.S. GEOLOGICAL SURVEY}

\section{Dallas L. Peck, Director}

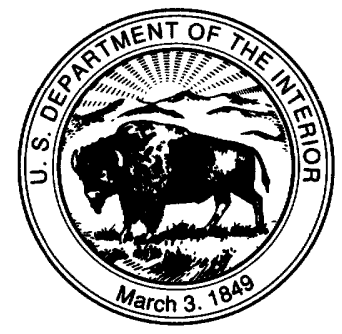

Any use of trade, product, or firm names

in this publication is for descriptive purposes only

and does not imply endorsement by the U.S. Government

For sale by the

Books and Open-File Reports Section

U.S. Geological Survey

Federal Center, Box 25425

Denver, CO 80225

\section{Library of Congress Cataloging-in-Publication Data}

Woods, Paul F.

Limnology of Big Lake, South-Central Alaska, 1983-84 / by Paul F. Woods.

p. $\quad \mathrm{cm}$. - (U.S. Geological Survey water-supply paper ; 2382) Includes bibliographical references.

1. Limnology-Alaska-Big Lake (Matanuska-Susitna Borough : Lake)

2. Primary productivity-Alaska-Big Lake (Matanuska-Susitna Borough : Lake)

3. Eutrophication-Alaska-Big Lake (Matanuska-Susitna Borough : Lake)

4. Big Lake (Matanuska-Susitna Borough, Alaska : Lake) I. Title. II. Series.

QH105.A4W665

$551.48^{\prime} 097983-\mathrm{dc} 20$ 1992

92-6329 


\section{CONTENTS}

Abstract 1

1.0 Introduction 2

1.1 Statement of problem 2

1.2 Purpose and scope 4

1.3 Description of the study area 6

1.3.1 Drainage basin 6

1.3.2 Lake morphometry 8

2.0 Study methods 10

2.1 Limnological stations and sampling schedule $\mathbf{1 0}$

2.2 Field sampling procedures $\mathbf{1 2}$

2.3 Laboratory procedures 14

2.4 Measurement of phytoplankton primary production $\mathbf{1 6}$

2.4.1 Introduction $\mathbf{1 6}$

2.4.2 Incubator experiments $\mathbf{1 8}$

2.4.3 Primary-production model $\mathbf{2 0}$

2.4.4 Expansion to annual lakewide primary production $\mathbf{2 2}$

3.0 Physical limnology 24

3.1 Climate characteristics during 1983-84 24

3.2 Solar irradiance $\mathbf{2 6}$

3.3 Reflection and extinction coefficients 28

3.4 Euphotic zone and epilimnion depths $\mathbf{3 0}$

3.5 Water temperature 32

3.5.1 East station $\mathbf{3 2}$

3.5.2 West station 34

4.0 Chemical limnology 36

4.1 Major cations and anions 36

4.2 Specific conductance $\mathbf{3 8}$

4.2.1 East station 38

4.2.2 West station $\mathbf{4 0}$

4.3 Dissolved oxygen $\mathbf{4 2}$

4.3.1 East station $\mathbf{4 2}$

4.3.2 West station 44

4.4 Percent saturation of dissolved oxygen $\mathbf{4 6}$

4.4.1 East station 46

4.4.2 West station $\mathbf{4 8}$

$4.5 \mathrm{pH} \quad \mathbf{5 0}$

4.5.1 East station $\mathbf{5 0}$

4.5.2 West station $\mathbf{5 2}$

4.6 Phosphorus 54

4.6.1 Total phosphorus $\mathbf{5 4}$

4.6.1.1 East station $\mathbf{5 4}$

4.6.1.2 West station $\mathbf{5 6}$

4.6.2 Dissolved orthophosphate $\mathbf{5 8}$

4.6.2.1 East station $\mathbf{5 8}$

4.6.2.2 West station 60

4.7 Nitrogen 62

4.7.1 Total ammonia plus organic nitrogen $\mathbf{6 2}$

4.7.1.1 East station $\mathbf{6 2}$

4.7.1.2 West station 64

4.7.2 Dissolved ammonia $\mathbf{6 6}$

4.7.2.1 East station 66

4.7.2.2 West station 68 
4.0 Chemical limnology-Continued

4.7 Nitrogen-Continued

4.7.3 Dissolved nitrite plus nitrate

4.7.3.1 East station $\mathbf{7 0}$

4.7.3.2 West station 72

4.8 Nitrogen-to-phosphorus ratios 74

5.0 Biological limnology 76

5.1 Chlorophyll- $a \quad 76$

5.1.1 East station $\mathbf{7 6}$

5.1.2 West station $\mathbf{7 8}$

5.2 Phytoplankton 80

5.2.1 Taxonomic listing $\mathbf{8 0}$

5.2.2 Percentage composition $\mathbf{8 2}$

5.2.3 Spatial and temporal trends in phytoplankton abundance 84

6.0 Primary production of phytoplankton 86

6.1 Annual rate $\mathbf{8 6}$

6.2 Monthly rates 88

6.3 Daily rates 90

6.3.1 East station 90

6.3.2 West station 92

6.4 Depth distribution of photoassimilation 94

7.0 Trophic state 96

7.1 Classification systems 96

7.2 Trophic state of Big Lake, 1983-84 98

7.3 Limnological effects of eutrophication $\mathbf{1 0 0}$

7.4 Nutrient-load/lake-response models $\mathbf{1 0 2}$

8.0 Summary and conclusions 104

9.0 References cited 106

Metric conversion factors and abbreviations 108 


\title{
Limnology of Big Lake, South-Central Alaska, 1983-84
}

\author{
By Paul F. Woods
}

\begin{abstract}
The limnological characteristics and trophic state of Big Lake in south-central Alaska were determined from the results of an intensive study during 1983-84. The study was begun in response to concern over the potential for eutrophication of Big Lake, which has experienced substantial residential development and recreational use because of its proximity to Anchorage.

The east and west basins of the 1,213 square-hectometer lake were each visited 36 times during the 2-year study to obtain a wide variety of physical, chemical, and biological data. During 1984, an estimate was made of the lake's annual primary production.

Big Lake was classified as oligotrophic on the basis of its annual mean values for total phosphorus (9.5 micrograms per liter), total nitrogen (209 micrograms per liter), chlorophyll-a ( 2.5 micrograms per liter), secchi-disc transparency (6.3 meters), and its mean daily integral primary production of $\mathbf{8 1 . 1}$ milligrams of carbon fixed per square meter. The lake was, however, uncharacteristic of oligotrophic lakes in that a severe dissolved-oxygen deficit developed within the hypolimnion during summer stratification and under winter ice cover. The summer dissolved-oxygen deficit resulted from the combination of strong and persistent thermal stratification, which developed within 1 week of the melting of the lake's ice cover in May, and the failure of the spring circulation to fully reaerate the hypolimnion. The autumn circulation did reaerate the entire water column, but the ensuing 6 months of ice and snow cover prevented atmospheric reaeration of the water column and led to development of the winter dissolved-oxygen deficit.

The anoxic conditions that eventually developed near the lake bottom allowed the release of nutrients from the bottom sediments and facilitated ammonification reactions. These processes yielded hypolimnetic concentrations of nitrogen and phosphorus compounds, which were much larger than the oligotrophic concentrations measured within the epilimnion. An analysis of nitrogen-to-phosphorus ratios showed that nitrogen was the nutrient most likely to limit phytoplankton growth during the summer.

Although mean chlorophyll-a concentrations were at oligotrophic levels, concentrations did peak at 46.5 micrograms per liter in the east basin. During each year and in both basins, the peak chlorophyll-a concentrations were measured within the hypolimnion because the euphotic zone commonly was deeper than the epilimnion during the summer.

The annual integral primary production of Big Lake in 1984 was 29.6 grams of carbon fixed per square meter with about 90 percent of that produced during May through October. During this time period, the lake received 76 percent of its annual input of solar irradiance. Monthly integral primary production, in milligrams of carbon fixed per square meter, ranged from 1.5 in January to 7,050 in July. When compared with the range of annual integral primary production measured in 50 International Biological Program lakes throughout the world, Big Lake had a low value of annual integral primary production.

The results of this study lend credence to the concerns about the potential eutrophication of Big Lake. Increases in the supply of oxygen-demanding materials to Big Lake could worsen the hypolimnetic dissolved-oxygen deficit and possibly shift the lake's trophic state toward mesotrophy or eutrophy.
\end{abstract}




\title{
1.0 INTRODUCTION
}

\subsection{Statement of Problem}

\section{Rapid Residential Development and Recreational Use of Big Lake Have Created Concern About the Potential for Eutrophication of This Popular South-Central Alaskan Lake}

\begin{abstract}
The fishery resources of Big Lake as well as its proximity to Anchorage have made the lake an extremely important aquatic resource for south-central Alaska. However, the current level of residential development of the lake's $27-\mathrm{km}$ shoreline has fostered concern that the lake may become enriched with nutrients leached from the numerous, individual septic systems near the lake.
\end{abstract}

The proximity of Big Lake to the rapidly developing communities of Anchorage, Eagle River, Palmer, and Wasilla has encouraged residential development and recreational use of this $1,213-\mathrm{hm}^{2}$ lake in the MatanuskaSusitna Borough of south-central Alaska (fig. 1.1). About 100 lakeshore cottages were already established at Big Lake in 1953, when it was considered the most popular fishing and boating lake in the Anchorage area (Allin, 1956). By 1976 the number of lakeshore residences had grown to about 450 . In 1985 the number of lakeshore residents was about 1,000 , most of whom disposed of their wastewater via individual, on-site septic systems because no community sewage facilities were available. The potential for contamination of Big Lake by septic-tank discharges into the nearshore, shallow aquifer was pointed out in a 1967 water-resources reconnaissance done by the U.S. Geological Survey (Feulner, 1971).

In 1976, the Alaska Department of Environmental Conservation found that wastewater disposal regulations were being violated at approximately one-half of the residences because of inadequate or improperly constructed sewage disposal systems (Epler, 1976). The level of residential development and recreational use of the lake's $27-\mathrm{km}$ shoreline and its numerous islands has fostered additional concern that the lake may be undergoing a process of cultural eutrophication. This is the process whereby excessive nutrient inputs to a lake stimulate its biological production to levels that degrade water quality and thus impair some or all of the lake's beneficial uses. The United Nations' Educational, Scientific, and Cultural Organization ranks the eutrophication of lakes and reservoirs as one of the most pervasive global water-pollution problems (Ryding and Rast, 1989).

Commercial and sport-fishery interests have a vital need to maintain the integrity of the aquatic ecosystem of Big Lake because it has been designated by the Alaska Department of Fish and Game as an extremely important aquatic ecosystem for the migration, spawning, and rearing of anadromous sockeye (Oncorhynchus nerka) and coho salmon (O. kisutch) (D.W. Collinsworth, Alaska Department of Fish and Game, written commun., 1983). The lake's production of sockeye and coho salmon has been augmented by a $\$ 1.5$ million (1978 costs) hatchery located $4 \mathrm{~km}$ upstream of Big Lake on Meadow Creek (fig. 1.1). Sport fishing at Big Lake accounts for about 16,000 person-days annually of fishing effort for rainbow trout (Oncorhynchus mykiss), Dolly Varden char (Salvelinus malma), and burbot (Lota lota) (L.J. Engel, Alaska Department of Fish and Game, oral commun., 1985).

To address these problems, a large-scale limnological study of the lake was begun by the U.S. Geological Survey, in cooperation with the Division of Geological and Geophysical Surveys of the Alaska Department of Natural Resources. 


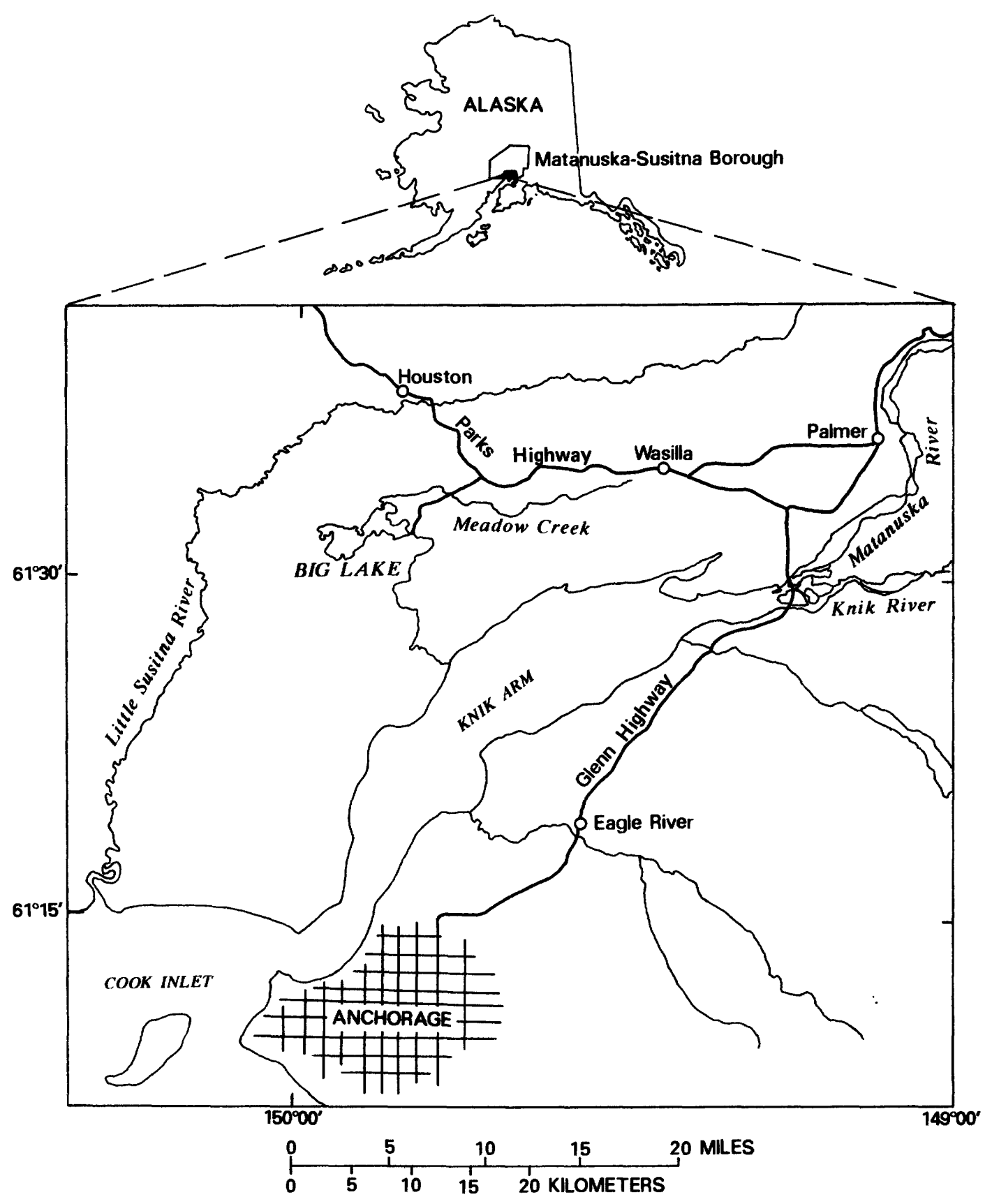

Figure 1.1. Location of Big Lake within the Matanuska-Susitna Borough of south-central Alaska. 


\title{
1.0 INTRODUCTION-Continued
}

\subsection{Purpose and Scope}

\section{Limnological Study of Big Lake During 1983-84 Sought to Ascertain Its Limnological Characteristics and Trophic State}

\begin{abstract}
Concerns over the potential for eutrophication of Big Lake led to a study of the lake during 1983-84. This report evaluates the lake's limnological characteristics and trophic state on the basis of the results of an intensive study of the lake's physical, chemical, and biological limnology.
\end{abstract}

The importance of the aquatic resources of Big Lake and the numerous concerns expressed over the potential for degradation of the lake's water quality have raised the question, "What is the current status of water quality in Big Lake?" An adequate answer to this question requires specialized limnological knowledge. As of 1982 , only a limited amount of water-quality data had been collected at Big Lake (Allin, 1954, 1956; LaPerriere, 1975; Lebida, 1983; U.S. Geological Survey, 1976). The study described in this report was done from January 1983 through December 1984 as part of the Alaska Water Resources Evaluation (AWARE), a statewide program for water-data collection and hydrologic studies (U.S. Geological Survey and Alaska Department of Natural Resources, 1984). The objective of the project was to investigate the limnological characteristics of Big Lake and ascertain the lake's trophic state.

This report describes and interprets spatial and temporal variations in numerous physical, chemical, and biological characteristics (fig. 1.2) in the two major basins of Big Lake during 1983-84. Selected limnological characteristics are then used to categorize the lake's trophic state.

Data collected during this limnological study have been used to produce three reports. The first report (Woods, 1984) described the field, laboratory, and computer procedures used to model the primary production of phytoplankton in Big Lake. Rowe (1987) summarized the seasonal variability of photosynthetically active radiation incident upon and within Big Lake during 198384. The third report described the distribution of chlorophyll- $a$ within Big Lake during 1983-84 and discussed how three different sampling designs affected the calculation of the lake's mean concentration of chlorophyll- $a$ (Woods, 1986). All the limnological data collected at the lake during 1983-84 are available in publications of the U.S. Geological Survey $(1984,1985$, 1986). 


\begin{tabular}{|lll|}
\hline \multicolumn{1}{|c|}{ Physical } & Chemical & \multicolumn{1}{c|}{ Blological } \\
\cline { 2 - 3 } $\begin{array}{l}\text { Photosynthetically } \\
\text { active radiation }\end{array}$ & Specific conductance & Chlorophyll-a \\
$\begin{array}{l}\text { Water-column } \\
\text { transparency }\end{array}$ & Dissolved oxygen & $\begin{array}{l}\text { Phytoplankton } \\
\text { species composition } \\
\text { and biomass }\end{array}$ \\
Water temperature & pH & $\begin{array}{l}\text { Phytoplanktonic } \\
\text { primary production }\end{array}$ \\
& Phosphorus & \\
& Nitrogen & \\
& Alkalinity and \\
& hardness & \\
& Cations and anions & \\
& &
\end{tabular}

Figure 1.2. Variables used to describe and interpret trends in limnological characteristics of Big Lake. 


\subsection{INTRODUCTION-Continued}

\subsection{Description of the Study Area}

\subsubsection{Drainage Basin}

\section{The Drainage Basin of Big Lake Is Underlain by Thick Glacial Deposits and Contains Numerous Muskegs, Ponds, and Lakes}

The $176-\mathrm{km}^{2}$ drainage basin of Big Lake is characterized by low-relief terrain containing numerous muskegs, ponds, and lakes. Big Lake, the largest lake in the drainage basin, receives its major surface-water inflow from Meadow Creek.

The 176-km² drainage basin of Big Lake (fig. 1.3.1) is characterized by low-relief terrain with elevations ranging from about 44 to $168 \mathrm{~m}$. The drainage basin has been glaciated several times (Karlstrom, 1953). Bedrock is buried beneath thick deposits of glacial drift and alluvial sediments composed chiefly of loose, coarse, sandy and gravelly material (Schoephorster, 1968). Most of Big Lake's drainage basin is underlain by well-drained, shallow, silty upland soils. Low-lying areas that border muskegs have poorly drained, stony soils. The welldrained soils are vegetated with paper birch, quaking aspen, and white spruce, whereas black spruce grow in the poorly drained areas. Muskegs contain sphagnum moss, sedges, and shrubs.

The climate of the Matanuska Valley area is characterized by a combination of maritime and continental influences. The Matanuska Agricultural Experiment Station, located $35 \mathrm{~km}$ east of Big Lake, is the nearest long-term climatological station (U.S. Department of Commerce, issued annually). Mean annual precipitation at the experiment station is $395 \mathrm{~mm}$. July is typically the wettest month with 16 percent of the annual precipitation. The mean annual evapotranspiration at the experiment station is esti- mated to be $381 \mathrm{~mm}$ (U.S. Department of Agriculture, 1982). The mean annual air temperature is $1.7^{\circ} \mathrm{C}$; July is the warmest month (mean temperature, $14.4^{\circ} \mathrm{C}$ ) and January, the coldest (mean temperature, $-11.4^{\circ} \mathrm{C}$ ). Normally, about 108 days have daily minimum temperatures higher than $0^{\circ} \mathrm{C}$ (Schoephorster, 1968). Ice forms on Big Lake in late October and melts by late May. Daylength at the $61^{\circ}$ latitude of Big Lake ranges from 5.5 hours on the winter solstice to 19.5 hours on the summer solstice.

The drainage basin contains numerous muskegs, ponds, and lakes. The principal lakes include Big, Big Beaver, Blodget, Flat, Jacobsen, Lucile, Rocky, Wallace, and West Beaver Lakes. Big Lake is the largest, with a 1,213-hm ${ }^{2}$ surface area. Big Lake's principal inlet stream is Meadow Creek, which is fed by Little Meadow Creek, and by Lucile Creek, which drains Lucile Lake. Big Lake is drained by Fish Creek, which enters Cook Inlet.

The ground-water resources in the Big Lake area were studied by Feulner (1971), who reported that most wells yielded water from interbedded sand-and-gravel lenses. Dearborn and Allely (1983) analyzed data for 92 water wells adjacent to Big Lake and reported that threefourths of them were less than $20 \mathrm{~m}$ deep. 


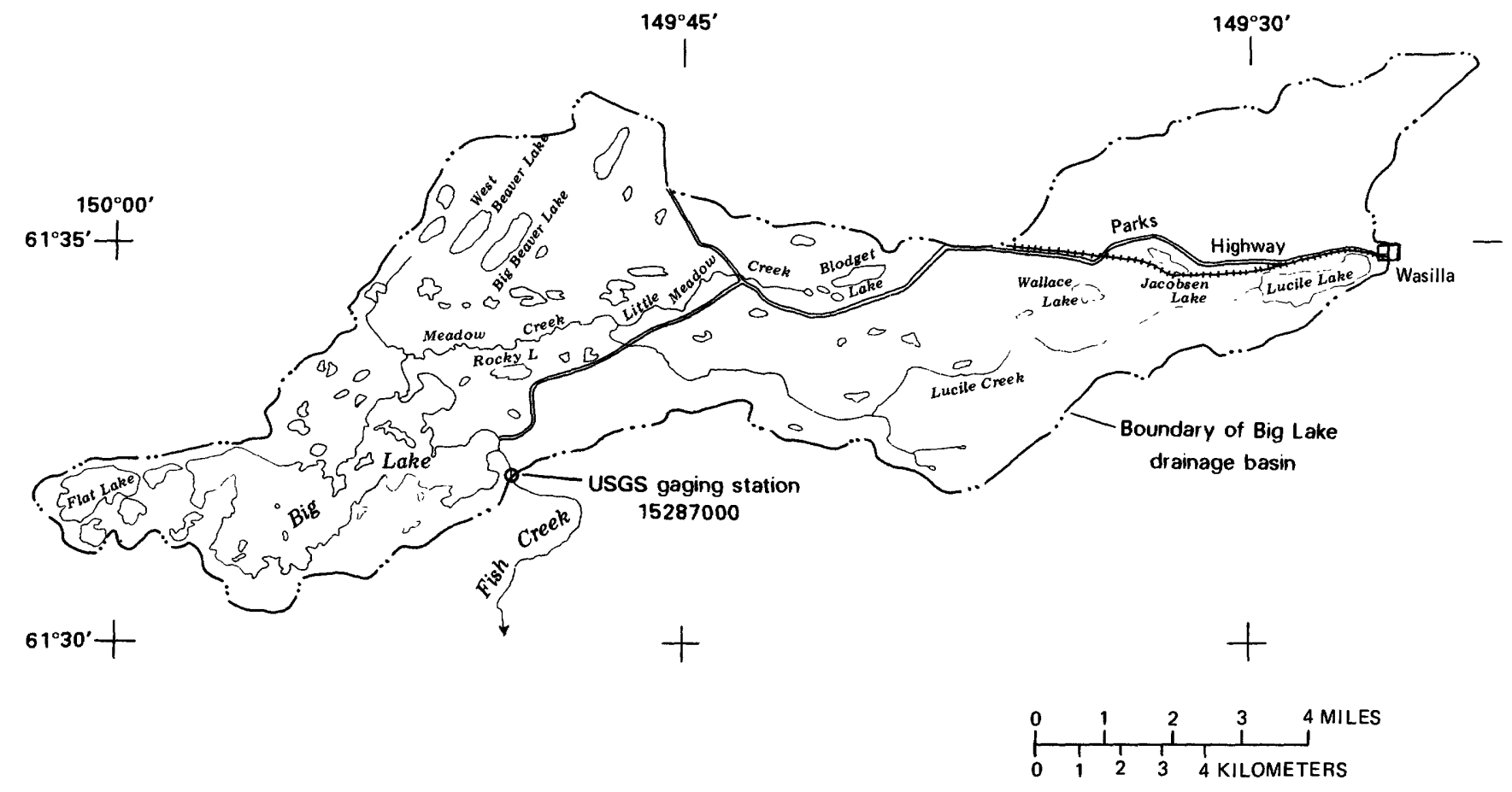

Figure 1.3.1. Drainage basin of Big Lake. 


\subsection{INTRODUCTION-Continued}

1.3 Description of the Study Area-Continued

1.3.2 Lake Morphometry

\section{Big Lake Covers an Area of 1,213 Square Hectometers and Reaches a Maximum Depth of 27 Meters}

The west basin of Big Lake has a maximum depth of $27 \mathrm{~m}$, whereas the east basin does not exceed $15.5 \mathrm{~m}$. The mean depth of the $1,213 \mathrm{hm}^{2}$ lake is $9.2 \mathrm{~m}$.

Big Lake consists of an east and a west basin connected by a constriction near the middle of the lake (fig. 1.3.2). The west basin encompasses 53.7 percent of the lake's $1,213-\mathrm{hm}^{2}$ surface area. The lake's major inlet stream, Meadow Creek, and the lake outlet into Fish Creek are in the east basin. The lake contains 22 islands having a combined surface area of $44.5 \mathrm{hm}^{2}$. The shoreline length, exclusive of islands, is $27.1 \mathrm{~km}$.
The bathymetry of the lake is shown in figure 1.3.2. The lake surface elevation is approximately $44 \mathrm{~m}$ and is controlled by a concrete fishweir structure. The lake contains $111.8 \mathrm{hm}^{3}$ of water and has a mean depth of $9.2 \mathrm{~m}$. The maximum depth of $27 \mathrm{~m}$ is in the west basin. The distribution of water in Big Lake within depth increments of $3.0 \mathrm{~m}$ is listed below.

$\begin{array}{crc}\begin{array}{c}\text { Depth interval } \\ (\mathrm{m})\end{array} & \begin{array}{l}\text { Volume } \\ \left(\mathrm{hm}^{3}\right)\end{array} & \begin{array}{c}\text { Percent of } \\ \text { total volume }\end{array} \\ 0-3 \ldots \ldots \ldots \ldots . . & 33.6 \ldots \ldots \ldots \ldots . & 30.0 \\ 3-6 \ldots \ldots \ldots \ldots . & 28.2 \ldots \ldots \ldots \ldots . & 25.2 \\ 6-9 \ldots \ldots \ldots \ldots . . & 22.4 \ldots \ldots \ldots \ldots . & 20.0 \\ 9-12 \ldots \ldots \ldots \ldots . & 13.9 \ldots \ldots \ldots . . & 12.4 \\ 12-15 \ldots \ldots \ldots \ldots . & 7.5 \ldots \ldots \ldots \ldots . & 6.7 \\ 15-18 \ldots \ldots \ldots \ldots . . & 4.0 \ldots \ldots \ldots \ldots . & 3.6 \\ 18-21 \ldots \ldots \ldots \ldots . & 1.6 \ldots \ldots \ldots \ldots . & 1.4 \\ 21-24 \ldots \ldots \ldots \ldots . . & .5 \ldots \ldots \ldots \ldots . & .4 \\ >24 \ldots \ldots \ldots \ldots . & .1 \ldots \ldots \ldots \ldots . & .1\end{array}$




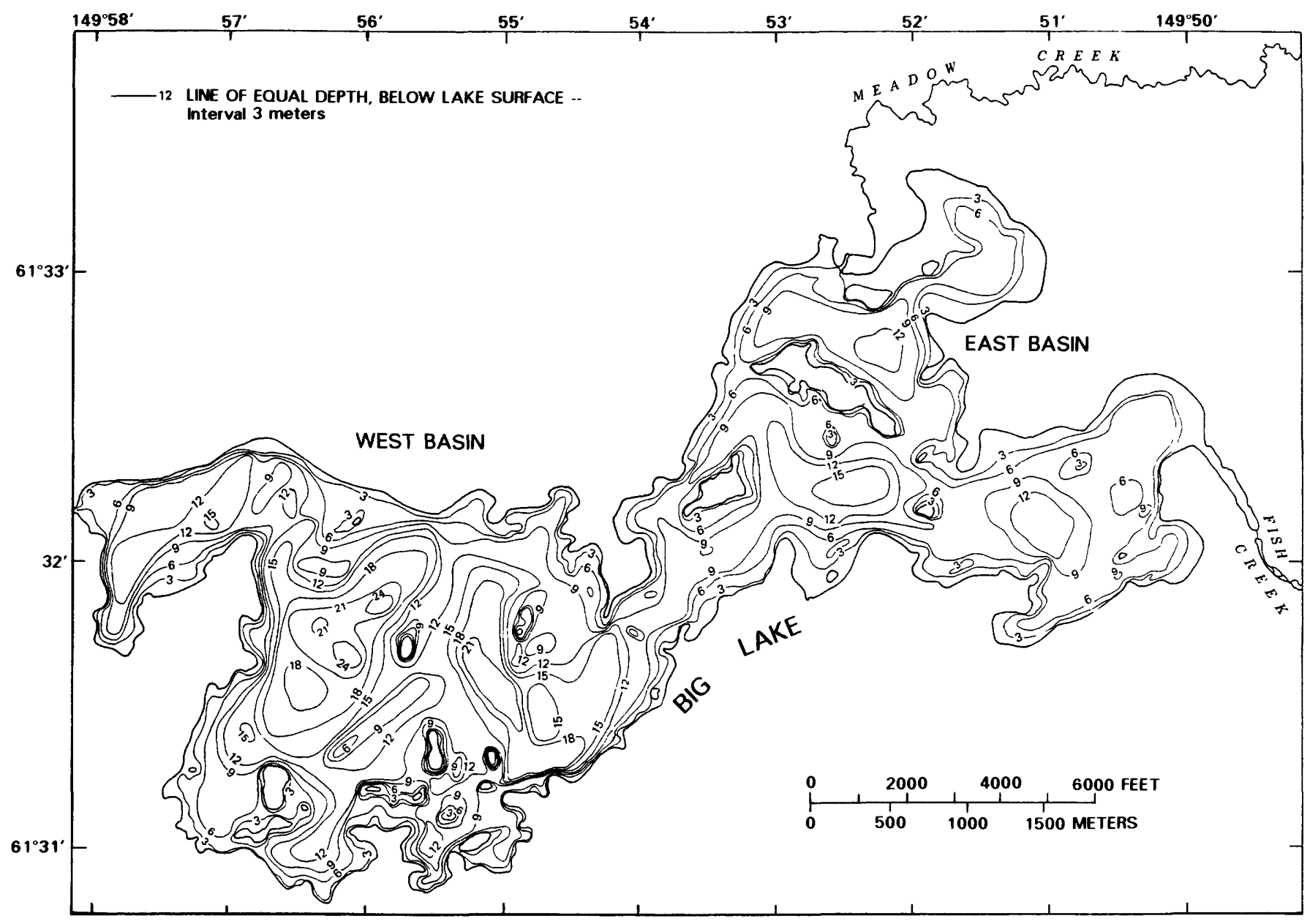

Figure 1.3.2. Bathymetry of Big Lake. 


\subsection{STUDY METHODS}

2.1 Limnological Stations and Sampling Schedule

\section{Limnological Data Were Collected About 18 Times Per Year During 1983-84 at Two Stations in East and West Basins of Big Lake}

Two stations were established at Big Lake for the collection of limnological data from January 1983 through December 1984. Data were collected biweekly during the openwater season and approximately monthly when ice covered the lake.

Two limnological stations (fig. 2.1) were established at Big Lake following a review of the lake's bathymetry and collection of reconnaissance-level watercolumn profiles. Limnological stations 1 and 2 represent the lake's west and east basins, respectively. Throughout this report, the two limnological stations are referred to as the west station (1) and the east station (2). Listed below are the station identification numbers and descrip- tions used by the U.S. Geological Survey (USGS) to formally identify the two limnological stations.

Limnological sampling was done from January 1983 through December 1984 at the west and east stations on a biweekly basis during the open-water season (late May to late October) and monthly when the lake was ice covered. However, samples were not collected when the ice cover was unstable during late October to early December and from mid-April to late May.
Limnological

station USGS station identification number and name

1

2

613150149554900 613215149522600
Big Lake northwest of Burston Island near Wasilla

Big Lake south of Long Island near Wasilla 


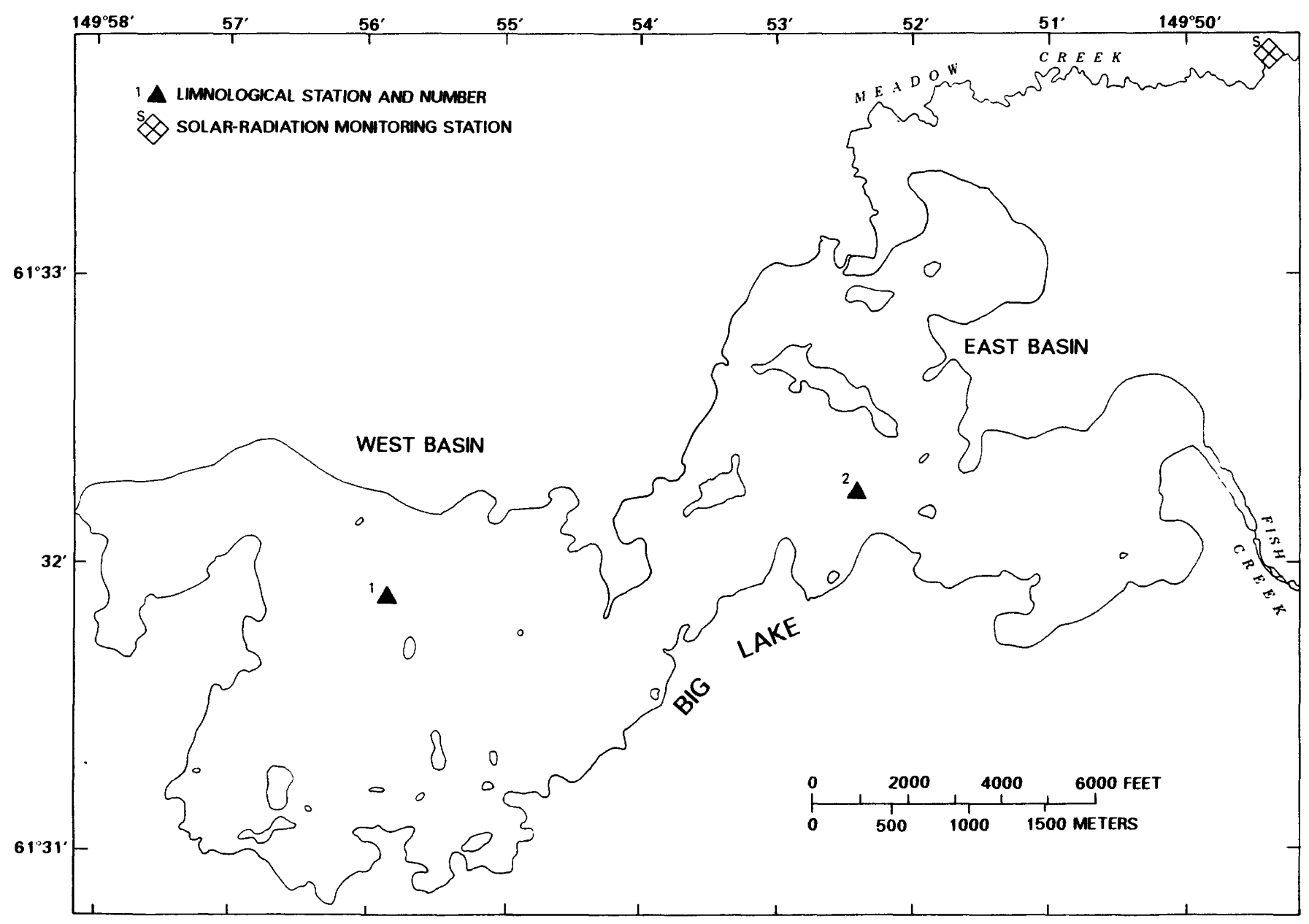

Figure 2.1. Location of limnological stations. 


\title{
2.0 STUDY METHODS—Continued
}

\subsection{Field Sampling Procedures}

\section{Limnological Sampling Included Profiling Water Column for Physical, Chemical, and Biological Variables and Collecting Water Samples for Chemical and Biological Analyses}

\begin{abstract}
The water column was profiled for temperature, specific conductance, $\mathrm{pH}$, dissolved-oxygen concentrations, and photosynthetically active radiation. Water samples were then collected at four or more depths for later analyses for chemical and biological variables, such as algal nutrients, chlorophyll-a concentration, and phytoplankton primary production.
\end{abstract}

Upon arrival of the observer at a sampling station, observations were made of wind speed and direction, percentage cloud cover, barometric pressure, air temperature, and any unusual lake or weather conditions. The water column was then profiled for temperature, $\mathrm{pH}$, specific conductance, and dissolved-oxygen concentration using a Hydrolab multiparameter water-quality instrument. Data were recorded at $0.5-\mathrm{m}$ depth intervals down to the thermocline and at $1.0-\mathrm{m}$ intervals beneath the thermocline.

The vertical distribution of photosynthetically active radiation (PAR) was then measured at $0.5-\mathrm{m}$ intervals using a spherical quantum sensor (Li-Cor, model LI193SB), which was suspended from a 2.5 -m-long horizontal boom to minimize boat-shadow effects on the in situ PAR readings. When taking PAR profiles through the ice cover, a semitransparent plate was placed over the ice hole and then snow was shoveled onto the plate to simulate the existing ice and snow cover on the lake. The PAR incident on the lake's surface was concurrently measured with a Li-Cor 190SB quantum sensor.

The in situ and incident PAR data were used to compute extinction and reflection coefficients according to the two equations shown in figure 2.2. Comparison of in situ PAR with incident PAR permitted location of the lower limit of the euphotic zone, defined here as the depth at which in situ PAR is 1.0 percent of that incident upon the lake surface. A 20 -cm-diameter secchi disc was used to measure water-column transparency.

Water samples for chemical and biological analyses and primary-production experiments then were obtained with an opaque 8-L water sampler. At the east station, samples were generally collected at depths of $2,6,10$, and $14 \mathrm{~m}$, whereas they were collected at $2,10,16$, and $24 \mathrm{~m}$ at the west station. During the winter, three widely spaced ice holes were used to separately profile and sample the water column to minimize disturbance of the weak inverse thermal stratification. Each depth sample was stored in a darkened carboy. Aliquots for inorganic carbon analyses were siphoned into darkened BOD bottles that were then kept chilled until analysis.

During 1983, chlorophyll- $a$ was sampled with numerous discrete-depth samples. In 1984, in vivo fluorometry was employed to profile the water column for a qualitative description of chlorophyll-a. Discrete-depth samples then were obtained at representative depths. Chlorophyll- $a$ samples were kept in darkened, chilled bottles prior to filtration. Following filtration, the filters were immediately frozen and then were stored frozen in the dark until analysis. 


$$
I_{z}=\left(I_{0}\right) e^{-n z}
$$

\section{EQUATION TO COMPUTE REFLECTION COEFFICIENT}

$$
R=1.0-\left(\begin{array}{l}
t_{z_{0}} \\
I_{0}
\end{array}\right)
$$

where $I_{z} \quad$ is PAR reading at depth $z$, in microEinsteins per square meter per second;

$I_{0} \quad$ is PAR reading immediately above lake surface, in microEinsteins per square meter per second;

$e \quad$ is base of natural logarithms, unitless;

$n \quad$ is extinction coefficient, in per meter;

$z \quad$ is depth beneath lake surface, in meters;

$R \quad$ is reflection coefficient, unitless; and

$I_{z_{0}}$ is PAR immediately beneath lake surface, ${ }^{1}$ in microEinsteins per square
meter per second.

\footnotetext{
${ }^{1}$ This value is predicted by regressing in situ PAR against depth.
}

Figure 2.2. Equations used to compute extinction and reflection coefficients. 


\subsection{STUDY METHODS—Continued}

\subsection{Laboratory Procedures}

\section{Most Water-Quality Samples Were Analyzed at the Alaska Department of Fish and Game's Limnology Laboratory}

The Alaska Department of Fish and Game's limnology laboratory analyzed the water samples for algal nutrients, and the U.S. Geological Survey's Central Laboratory analyzed the samples for major cations and anions. Concentrations of chlorophyll-a and inorganic carbon were determined in the Alaska District's Anchorage laboratory.

The water-quality samples were analyzed or processed for later analysis at the U.S. Geological Survey's laboratory in Anchorage. Inorganic carbon concentrations were analyzed on an infrared carbon analyzer (Oceanographic International Corporation model 525 with Horiba PIR-2000). The fluorometric methodology of Wetzel and Likens (1979) was used to determine concentrations of chlorophyll- $a$, corrected for pheophytin.

The Alaska Department of Fish and Game's limnology laboratory (fig. 2.3) analyzed the water-quality samples for the following constituents using methods of Koenings and others (1987): total phosphorus, dissolved orthophosphate, total ammonia plus organic nitrogen, dissolved ammonia, and dissolved nitrite plus nitrate. The lab successfully participated in the U.S. Geological Survey's Standard Water Reference Sample Program. Phytoplankton samples were preserved with Lugols-acetate and were later analyzed for taxonomic composition and cell carbon by a contractor to the limnology laboratory. On four occasions (late May and mid-September of 1983, late March and May of 1984), samples were sent to the U.S. Geological Survey's Central Laboratory in Denver, Colorado, for determination of major cations and anions using methods described by Skougstad and others (1979). 


\section{LIMNOLOGY \\ FIELD \& LABORATORY MANUAL}
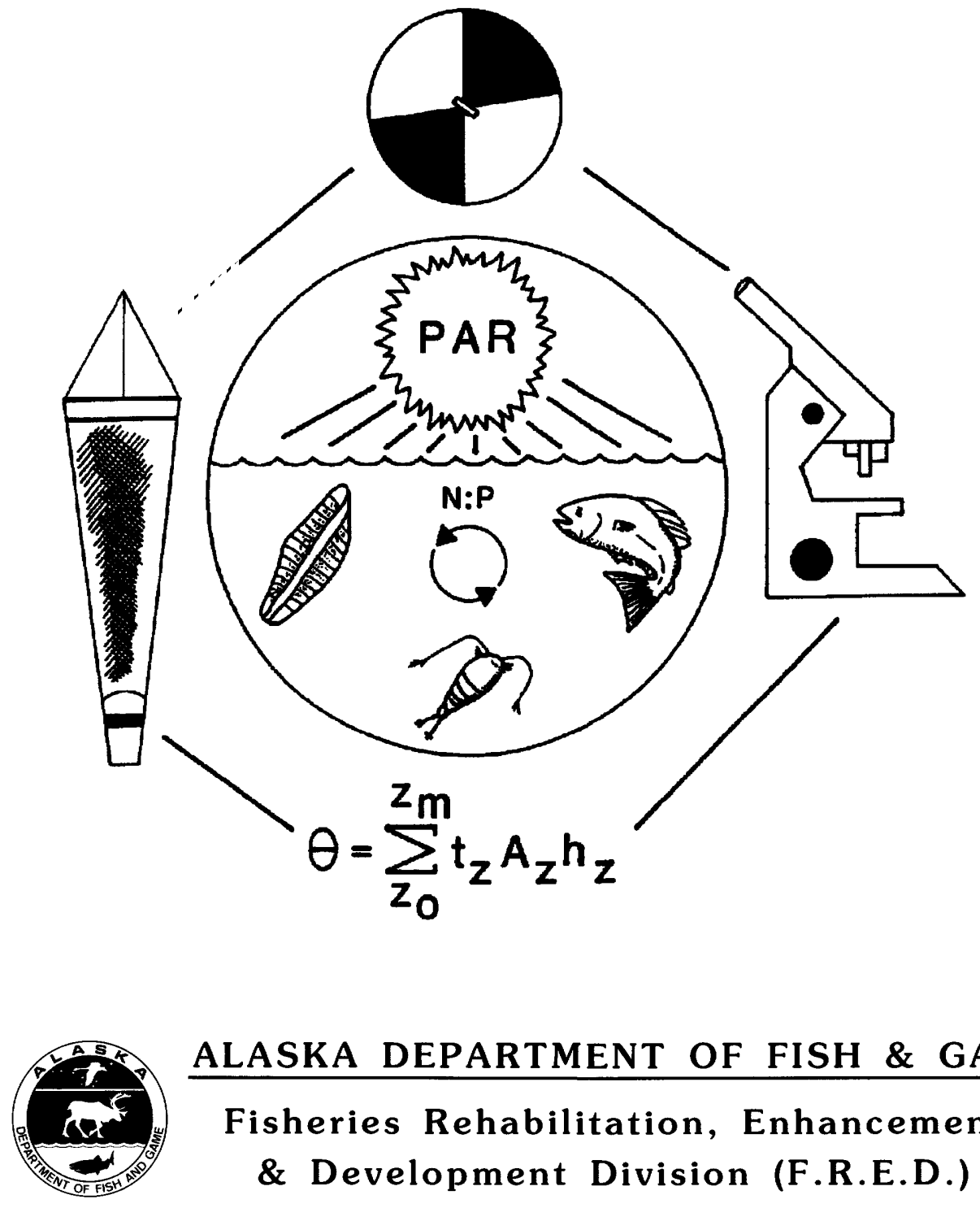

\section{ALASKA DEPARTMENT OF FISH \& GAME}

Fisheries Rehabilitation, Enhancement \& Development Division (F.R.E.D.) Limnology Section

Figure 2.3. Cover of Alaska Department of Fish and Game's Limnology Field and Laboratory Manual. 


\subsection{STUDY METHODS—Continued}

\subsection{Measurements of Phytoplankton Primary Production}

\subsubsection{Introduction}

\section{Estimate of Big Lake's Annual Primary Production During 1984 Was Made With a Computer Model Using Limnological Data, Solar-Irradiance Records, and Results of Primary-Production Experiments}

Daily rates of phytoplankton primary production throughout the euphotic zone were determined with a computer model. A major input for the model was the rate of photoassimilation by phytoplankton. Photoassimilation rates were measured with the carbon-14, light-and-dark-bottle methodology.

Studies of phytoplankton primary production require measurements of the rate of photoassimilation by phytoplankton sampled from selected depths. The rates thus obtained generally are reported as the quantity fixed per cubic meter per hour. These hourly rates were then expanded into daily photoassimilation rates. Integration of the daily photoassimilation rates measured in the water column yields the quantity of organic matter fixed per day under a square meter of lake surface area. This value is termed daily integral primary production.
Hourly rates of phytoplankton photoassimilation in Big Lake were measured during 1984 with the carbon-14 light-and-dark-bottle method in conjunction with a constantlight, water-bath incubator. The results of the incubator experiments were combined with selected limnological data and hourly records of solar irradiance and were input to a computer model (fig. 2.4.1). The model computed daily integral primary production for each day with solarirradiance data. The final value sought was an estimate of the annual integral primary production by phytoplankton within the lakewide euphotic zone of Big Lake. 


\section{LIMNOLOGICAL DATA}<smiles>[CH]</smiles>

INCUBATOR EXPERIMENTS

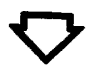

PRIMARY-PRODUCTION MODEL

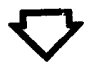

EXPANSION TO ANNUAL LAKEWIDE VALUES

Figure 2.4.1. Procedural steps for modeling annual primary production. 


\title{
2.0 STUDY METHODS-Continued
}

\subsection{Measurement of Phytoplankton Primary Production-Continued}

\subsubsection{Incubator Experiments}

\section{Functional Relation Between Photoassimilation and Various Amounts of Photosynthetically Active Radiation Was Experimentally Determined in Constant-Light, Water-Bath Incubator}

\begin{abstract}
A constant-light, water-bath incubator was used to experimentally determine the rate of photoassimilation as measured by carbon-14 methods, at various levels of photosynthetically active radiation. After incubation, the contents of light, dark, and zero-time blank bottles were filtered onto glass-fiber filters. The filters were later assayed for retained carbon-14 activity using a liquid scintillation spectrophotometer.
\end{abstract}

The goal of the incubator experiments was to derive the functional relation between photoassimilation and various amounts of PAR. This was accomplished by exposing phytoplankton samples to different amounts of PAR in a five-chambered, constant-light, water-bath incubator. The incubator is an extensively modified version of an incubator described by Shearer (1976). The carboys filled at Big Lake were used to fill 11 light (clear) bottles and one dark (opaque) bottle for each depth sampled. Each $60-\mathrm{mL}$ sample bottle was then inoculated with $100 \mu \mathrm{L}$ of radioactive tracer (carbon-14 in sodium bicarbonate solution, activity of $27 \mu \mathrm{Ci} / \mathrm{mL}$ ). Two light bottles from each depth were placed in each of the incubator's five chambers. The algae in the remaining light bottle for each depth were killed shortly after filling by injecting the sample with $250 \mu \mathrm{L}$ of Lugols-acetate solution. These bottles served as zerotime blanks. Each dark bottle was incubated in the rearmost chamber and was used to quantify both nonphotosynthetic uptake and inactive fixation of carbon-14. The PAR in each chamber was measured before and after incubation with the instrumentation used to measure PAR within Big Lake. Removable screens between the light source, a 400-W metal halide lamp, and each chamber permitted adjustment of PAR in the incubator. During the 3- to 4-hour incubation, the bottles were constantly rotated to simulate water-column turbulence and prevent settling of particulates. A circulating water system allowed control of the incubator's water temperature during the incubation. To avoid excessive thermal shock to the phytoplankton, samples were incubated at temperatures near those of the depths sampled.

Immediately after incubation, the algae in the light and dark bottles were killed with an injection of the Lugols-acetate and were then vacuum-filtered onto glassfiber filters. The carbon-14 assimilated by the phytoplankton during incubation was retained on the filters. The radioactivity on the filters was measured with a liquid scintillation spectrophotometer using methods of Koenings and others (1987).

The hourly rate of photoassimilation can be calculated with the equation shown in figure 2.4.2.1. The results from this equation for each of the incubator's five chambers were plotted against the PAR values measured in each chamber (fig. 2.4.2.2). These data pairs then were input to the primary-production model. 


\section{EOUATION TO COMPUIE HOURLY RATE OF PHOTOASSIMILATION}

$H=\frac{(c)\left(d_{s}-d_{b}\right) \frac{V_{1}}{V_{f}}(I)(f)}{\left(d_{t}\right)(t)}$

where $\quad H$ is hourly rate of photoassimilation, in milligrams of carbon fixed per cubic meter per hour;

c is inorganic carbon concentration, in milligrams per liter;

d is disintegrations per minute of incubated sample;

$d_{b}$ is disintegrations per minute of zero-time blank;

$V$ is volume of sample bottle, in milliliters;

$V_{f}$ is volume of sample filtered, in milliliters;

$I \quad$ is an isotope discrimination factor (1.06);

$f \quad$ is a factor $(1,000)$ to convert liters to cubic meters;

d is disintegrations per minute originally added to incubated sample; and

$t$ is incubation time, in hours.

Figure 2.4.2.1. Equation used to compute hourly rate of photoassimilation.

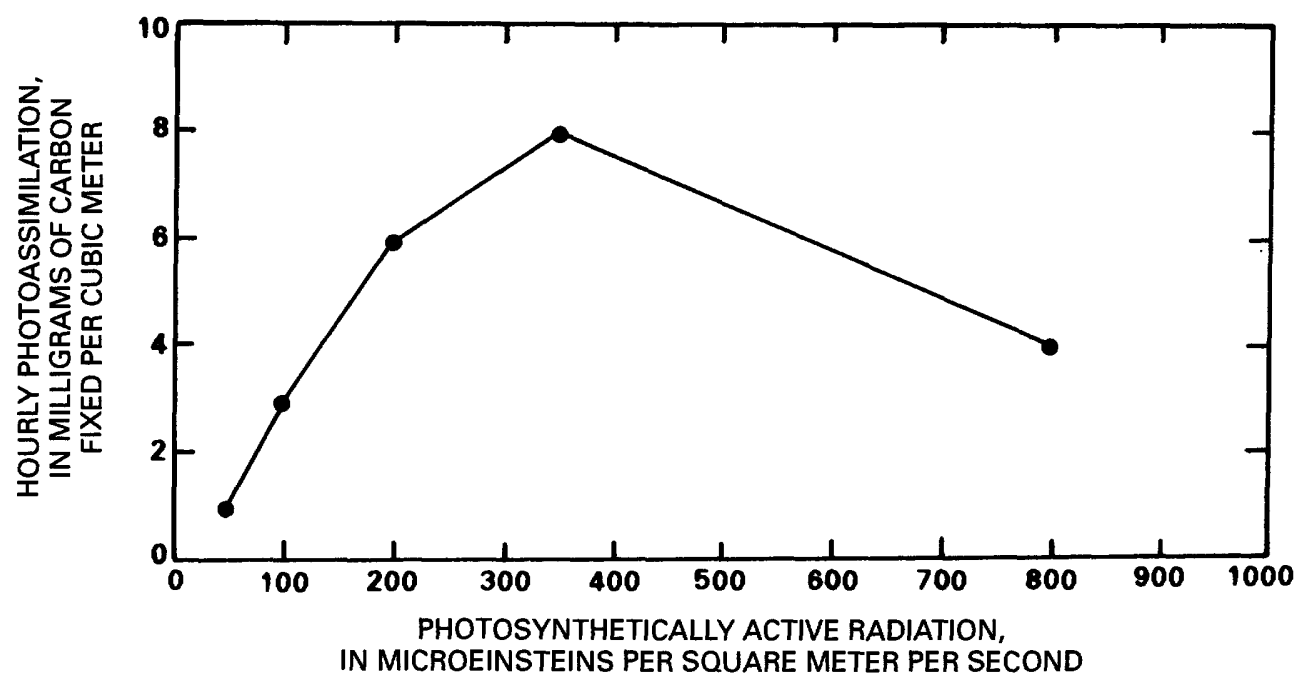

Figure 2.4.2.2. Relation of photosynthetically active radiation to hourly photoassimilation. 


\title{
2.0 STUDY METHODS-Continued
}

2.4 Measurement of Phytoplankton Primary Production-Continued

2.4.3 Primary-Production Model

\section{A Computer Model (BIOMOD) Generated Hourly Rates of Phytoplankton Photoassimilation at 1-Meter Depth Intervals Throughout the Euphotic Zone. Values Were Summed Over Depth and Time to Yield Daily Integral Primary Production}

\begin{abstract}
Daily integral primary production by phytoplankton was computed by a computer model called BIOMOD. Major input data for BIOMOD include the following: profiles of water temperature, chlorophyll-a concentrations, and PAR; and the photoassimilation-PAR curves generated by the incubator experiments.
\end{abstract}

The data obtained from the incubator experiments, limnological sampling, and the solar-irradiance monitor were input to a computer model for computation of primary production. An earlier version of this model was developed by Jasper and others (1983) to study primary production in Kootenay Lake, British Columbia. The version used at Big Lake is a Fortran program named BIOMOD.

The model computes daily integral primary production over the time interval between two sampling dates specified by the model user. Data for each sampling date must include the following: water-temperature profile, chlorophyll- $a$ profile, extinction coefficient, and a curve relating hourly photoassimilation to PAR. The photoassimilation-PAR curves must also define the sampling depths that they represent and the incubation temperatures of the samples taken from these depths. The model user also specifies the integration interval (usually $1 \mathrm{~m}$ ), the depth of integration, the reflection coefficient, and a temperature correction coefficient. Solar-irradiance data, recorded as PAR and at 1-hour intervals, are input for each day to be computed. The solar-irradiance monitor was located about $2 \mathrm{~km}$ northeast of Big Lake at the Big Lake hatchery (fig. 2.1) and continuously recorded data over the 2-year duration of the study.

The temperature and chlorophyll data for both sampling dates are linearly interpolated to fill in data for those depths not sampled. These depth profiles then are used to linearly interpolate values of temperature and chlorophyll for days between the two sampling dates.

The PAR values at each depth on both sampling dates are computed as shown in the equation in figure 2.4.3. The $\mathrm{PAR}_{z}$ values between the two sampling dates are computed in a similar manner; however, the extinction coefficient for each day is interpolated from the extinction coefficients measured on the two sampling dates.

The photoassimilations for both sampling dates are normalized with respect to their associated chlorophyll- $a$ concentrations, and the resultant values are then interpolated over the depth to be integrated for both sampling dates. The two profiles of chlorophyll-normalized photoassimilation are then interpolated over the days between the two sampling dates.

The model then finds a PAR value for each depth on each day and multiplies each value by its appropriate chlorophyll-normalized, hourly photoassimilation. These values are then multiplied by their associated chlorophyll- $a$ concentration to achieve hourly rates of photoassimilation per cubic meter for each depth on each day of the specified interval. The second equation in figure 2.4.3 further modifies these values by correcting them for differences between in situ and incubator temperatures. The temperature-corrected values of hourly photoassimilation then are summed over depth and time to yield daily integral primary production. 


$$
\operatorname{PAR}_{z}=(1.0-R)\left(\text { PAR }_{s}\right)\left(e^{-n z}\right)
$$

where PAR $_{z}$ is PAR at specified depth, in microEinsteins per square meter per second;

$z \quad$ is depth, in meters;

$\boldsymbol{R} \quad$ is reflection coefficient, unitless;

PAR $_{s}$ is PAR measured by solar-irradiance monitor, in microEinsteins per square meter per second;

e is base of natural logarithms, unitless; and

$n \quad$ is extinction coefficient, in per meter.

\section{EQUATION TO COMPUTE TEMPERATURE-CORRECTED VALUES OF HOURLY PHOTOASSIMILATION}

$$
H=(P)\left(Q_{10}\right)\left(t_{z}-t_{1}\right) / 10
$$

where $H \quad$ is temperature-corrected hourly photoassimilation, in milligrams of carbon fixed per cubic meter per hour;

$P \quad$ is non-temperature-corrected hourly photoassimilation, in milligrams of carbon fixed per cubic meter per hour;

$Q_{10}$ is temperature-correction coefficient, unitless;

$t_{z} \quad$ is in situ water temperature, in degrees Celsius; and

$t_{1}$ is incubator water temperature, in degrees Celsius.

Figure 2.4.3. Equations used to compute photosynthetically active radiation at a specified depth and temperature-corrected values of hourly photoassimilation. 


\subsection{STUDY METHODS-Continued}

2.4 Measurement of Phytoplankton Primary Production-Continued

2.4.4 Expansion to Annual Lakewide Primary Production

\section{Annual Lakewide Primary Production at Big Lake Was Determined From Results of Primary-Production Modeling for East and West Limnological Stations}

Annual integral primary production, on a per square meter basis, was computed for the east and west limnological stations. The proportion of lake surface area represented by these two stations was used to compute their contribution to the annual integral primary

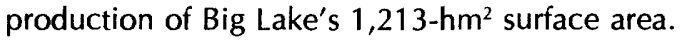

The daily integral primary-production values generated by the model were summed over the 1984 calendar year to obtain the annual integral primary production of the sampling station under consideration. Each station's summation represented the annual primary production within the water column under a square meter of lake surface.
To obtain an annual lakewide value, the lake's surface area was apportioned into those regions represented by the primary-productivity sampling stations. There were two such stations on Big Lake: one in the east basin, the other in the west basin. The annual lakewide primary production of Big Lake could then be calculated as shown in figure 2.4.4. 


$$
L=\left(P_{\mathrm{E}} \times S_{\mathrm{E}}\right)+\left(P_{\mathrm{W}} \times S_{\mathrm{W}}\right)
$$

where $L \quad$ is annual lakewide primary production, in milligrams of carbon fixed per year;

$P_{E} \quad$ is annual integral primary production measured in east basin of Big Lake, in milligrams of carbon fixed per square meter per year;

$S_{E} \quad$ is lake surface area of east basin of Big Lake, in square meters;

$P_{w} \quad$ is annual integral primary production measured in west basin of Big Lake, in milligrams of carbon fixed per square meter per year;

$S_{w} \quad$ is lake surface area of west basin of Big Lake, in square meters.

West basin surface area equals 65,140 square meters

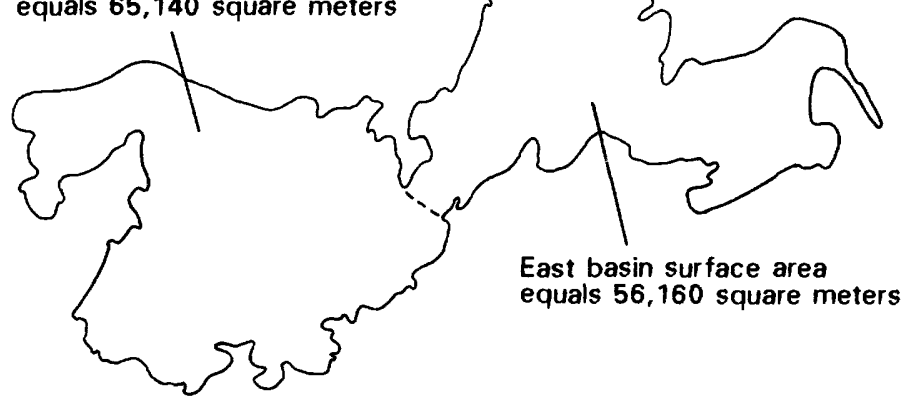

Figure 2.4.4. Equation used to compute lakewide primary production. 


\title{
3.0 PHYSICAL LIMNOLOGY
}

\subsection{Climate Characteristics During 1983-84}

\section{Climate at Big Lake During 1983-84 Was Characterized by Higher Than Normal Annual Mean Air Temperatures and Lower Than Normal Annual Precipitation}

\begin{abstract}
The long-term mean annual air temperature of $1.72^{\circ} \mathrm{C}$ was exceeded at Big Lake during 1983 and 1984 largely because winters were warmer than normal. The long-term mean annual precipitation of $395.2 \mathrm{~mm}$ exceeded the 1983 and 1984 annual precipitation. In both years, March was the driest month and July the wettest. The lake's ice cover melted in mid-May and re-formed in late October in both years.
\end{abstract}

Annual mean air temperatures in $1983\left(2.61^{\circ} \mathrm{C}\right)$ and $1984\left(2.22^{\circ} \mathrm{C}\right)$ were slightly higher than the mean annual air temperature of $1.72^{\circ} \mathrm{C}$ recorded at the Matanuska Agricultural Experiment Station. During 1983-84, the monthly mean air temperatures ranged from $-9.7^{\circ} \mathrm{C}$ (January 1983 ) to $13.9^{\circ} \mathrm{C}$ (July 1983); the normal range in mean monthly air temperatures is $-11.4^{\circ} \mathrm{C}$ (January) to $14.4^{\circ} \mathrm{C}$ (July). In both years, the winter months tended to be warmer than normal by several degrees, and the summer months were slightly cooler than normal (fig. 3.1). In 1983 there were 109 days (May 19 to September 5) with daily mean air temperatures higher than $0^{\circ} \mathrm{C}$; 91 such days (May 29 to August 27) occurred in 1984. Big Lake was free of ice cover from May 20 to October 23, 1983, and from May 16 to October 30, 1984. The ice cover at the east station attained a maximum thickness of $0.9 \mathrm{~m}$ in both years, as did the west station in 1983 . In 1984 the ice cover at the west station was only $0.6 \mathrm{~m}$ thick.

The mean annual precipitation of $395.2 \mathrm{~mm}$ reported for the Matanuska Agricultural Experiment Station was greater than the annual precipitation for $1983(325.8 \mathrm{~mm})$ and $1984(354.8 \mathrm{~mm})$. Monthly precipitation ranged from $0.0 \mathrm{~mm}$ (March 1983) to $118.1 \mathrm{~mm}$ (July 1983) during 1983-84 (fig. 3.1). The normal range in monthly precipitation is $13.5 \mathrm{~mm}$ in March to $63.5 \mathrm{~mm}$ for July. During 1983 , the winter months were drier than normal but July was substantially wetter than normal. Four months in 1984 were substantially drier than normal, but only August was much wetter than normal. 

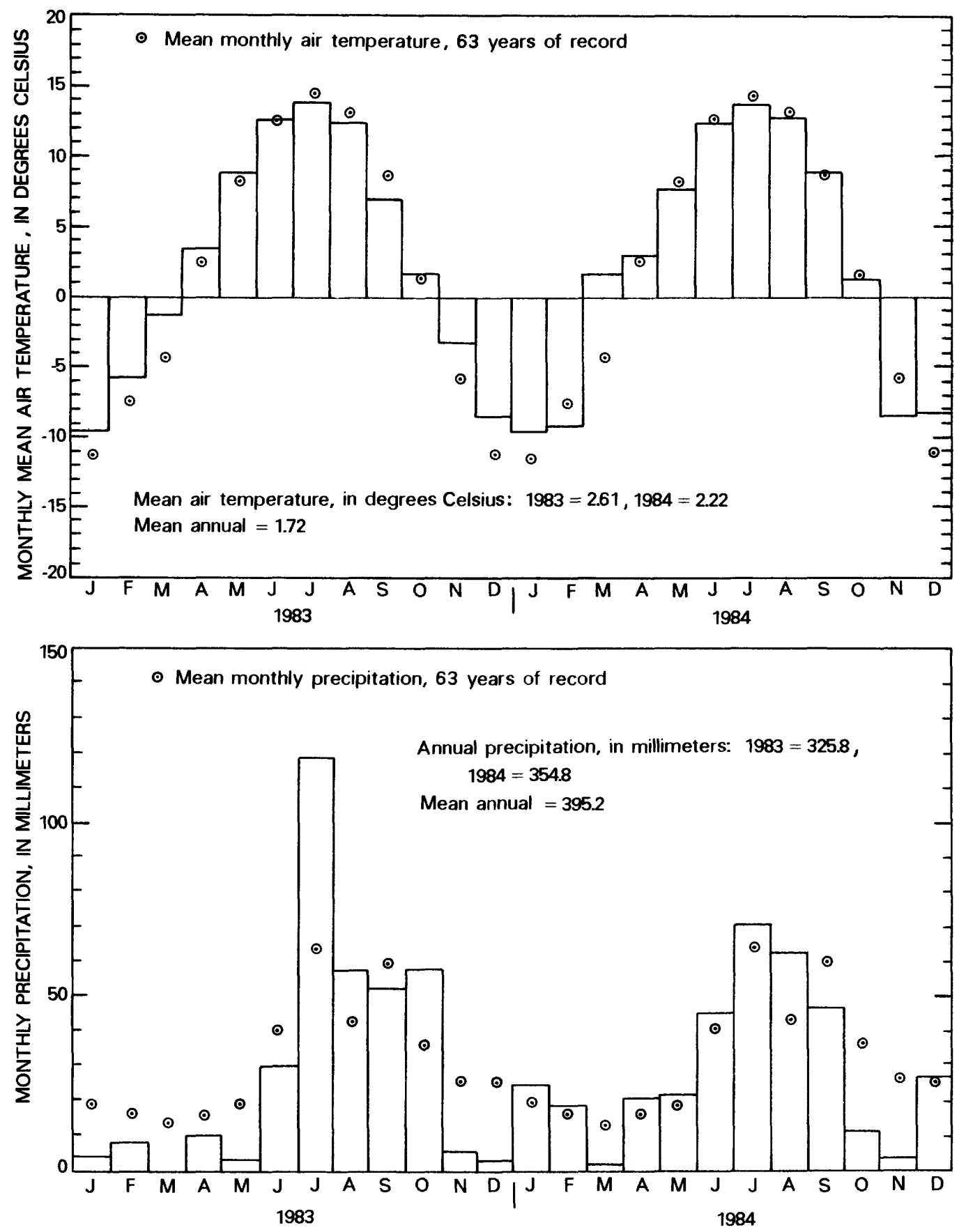

Figure 3.1. Monthly mean air temperatures and monthly precipitation near Big Lake during 1983-84. 


\title{
3.0 PHYSICAL LIMNOLOGY-Continued
}

\subsection{Solar Irradiance}

\section{Approximately 76 Percent of Annual Solar Irradiance, Measured as Photosynthetically Active Radiation, Was Input to Big Lake During May Through October}

\begin{abstract}
The annual input of photosynthetically active radiation averaged 6,288 Einsteins per square meter during 1983-84. On a monthly basis, photosynthetically active radiation ranged from 12 to 1,247 Einsteins per square meter and exhibited a pronounced seasonality due to changes in daylength and meteorological conditions.
\end{abstract}

The input of solar irradiance to the surface of Big Lake was measured as photosynthetically active radiation, or PAR, which is that part of the visible spectrum lying between 400 and $700 \mathrm{~nm}$. The solar-irradiance monitor measured instantaneous PAR, in microEinsteins per square meter per second $\left(\mu \mathrm{E} / \mathrm{m}^{2} / \mathrm{s}\right)$ but recorded the data as hourly PAR, in Einsteins per square meter per hour $\left(E / \mathrm{m}^{2} / \mathrm{hr}\right)$. The hourly values were variously summed into daily, monthly, and annual values.

The annual input of PAR in 1983 was $6,238.8 \mathrm{E} / \mathrm{m}^{2}$, which was slightly less than the $6,337.3 \mathrm{E} / \mathrm{m}^{2}$ input during 1984. As shown in figure 3.2, there was a pronounced seasonality in the monthly input of PAR. The range in monthly PAR, in Einsteins per square meter, was from 12 (December 1984) to 1,247 (June 1983). During both years, 76 percent of the annual PAR was input to the lake during May through October. The large differences in monthly inputs between the winter and summer months were due mostly to changes in daylength, although seasonal meteorological conditions also affect PAR inputs. The effect of daylength can be illustrated by comparing the PAR inputs of the summer and winter solstices of 1983. On June 21 , with $19.5 \mathrm{hr}$ of daylight, the lake received $55.8 \mathrm{E} / \mathrm{m}^{2}$ of PAR, whereas on December 21, with $5.5 \mathrm{hr}$ of daylight, it had a PAR input of only $0.9 \mathrm{E} / \mathrm{m}^{2}$.

The effects of changing meteorological conditions are readily apparent in comparisons of daily and hourly PAR values. On a clear, sunny day in June 1983, Big Lake received $56.3 \mathrm{E} / \mathrm{m}^{2}$ of PAR; on the following overcast day, the lake received only $19.2 \mathrm{E} / \mathrm{m}^{2}$ of PAR. Phytoplankton photosynthesis is sensitive to short-term fluctuations in PAR; thus the primary-production model used in the Big Lake study relied on hourly PAR values. There were often substantial differences in hourly PAR within a single day. For example, during midday of June $12,1984,5.56 \mathrm{E} / \mathrm{m}^{2}$ of PAR were input between 13:00 and 14:00, but during the following hour, the lake received only $2.14 \mathrm{E} / \mathrm{m}^{2}$ of PAR. The next hour's PAR increased to $5.52 \mathrm{E} / \mathrm{m}^{2}$. Intermittent cloudiness can thus cause significant reductions in PAR inputs even over a few hours. 


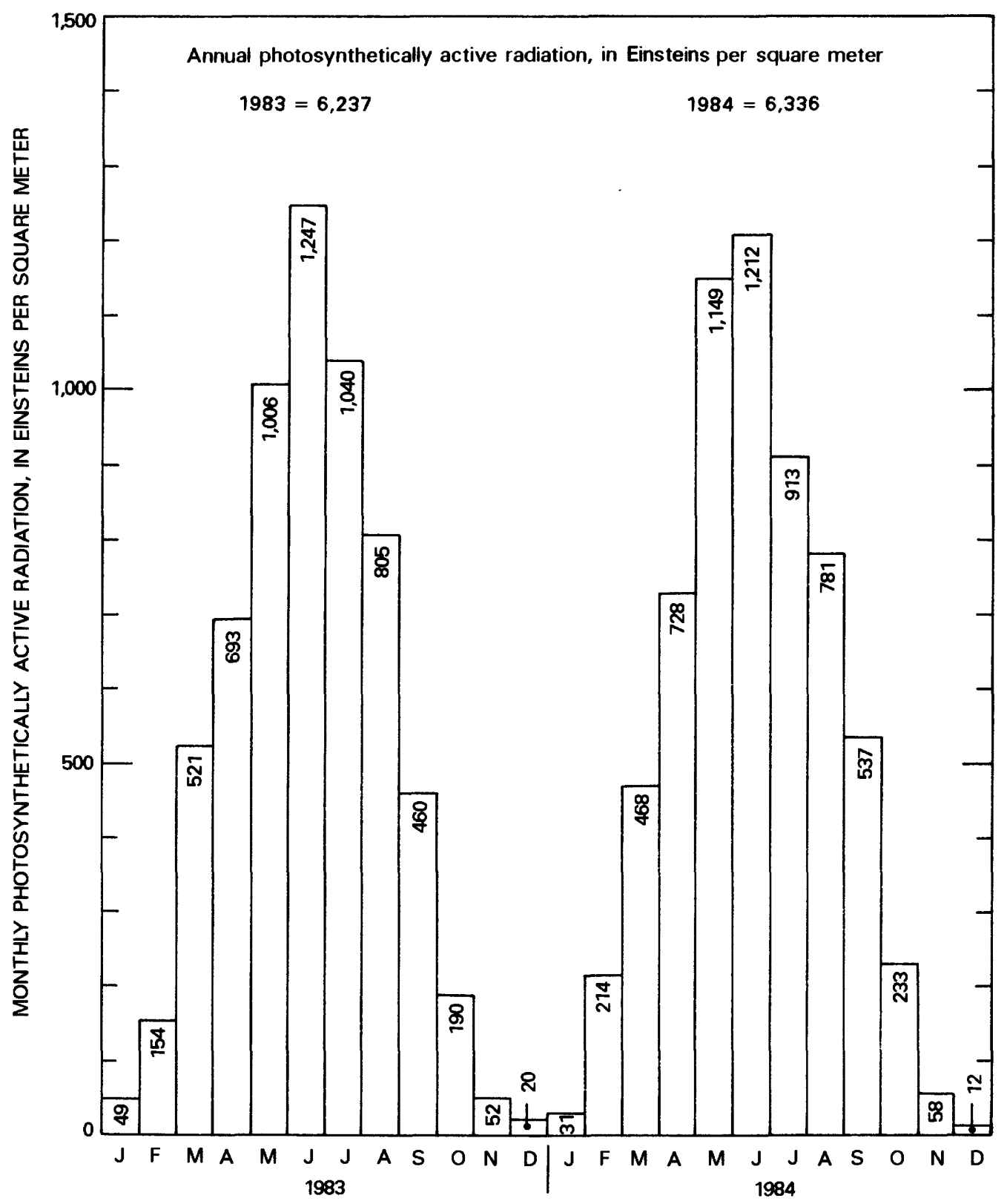

Figure 3.2. Monthly photosynthetically active radiation received at Big Lake during 1983-84. 


\title{
3.0 PHYSICAL LIMNOLOGY-Continued
}

\subsection{Reflection and Extinction Coefficients}

\section{Extinction Coefficients Measured at Two Limnological Stations Were Characteristic of Clear-Water Lakes}

\begin{abstract}
The ice and snow cover on Big Lake reflected more than 80 percent of the incident solar radiation, whereas the lake's open-water surface reflected only 5 to 44 percent. Extinction coefficients within the water column varied from 0.30 to 0.67 ; the east station normally had the larger extinction coefficients and thus attenuated solar irradiance more rapidly than did the west station.
\end{abstract}

The part of solar irradiance not reflected from Big Lake's surface entered the water column, where it was attenuated by scattering and absorption. An extinction coefficient is commonly used to quantify the watercolumn attenuation of PAR. The variation in reflection and extinction coefficients at the east and west stations is shown in figure 3.3. During the open-water season, the reflection coefficient ranged from 0.05 to 0.44 ; however, the lake's ice and snow cover yielded reflection coefficients in excess of 0.80 . The amount of PAR available beneath the lake's ice cover was thus limited by a combination of high reflection coefficients and the seasonally reduced input of PAR to the lake surface. For example, on the winter solstice of 1983 the PAR received at the lake's surface was $0.9 \mathrm{E} / \mathrm{m}^{2}$. This was reduced to $0.04 \mathrm{E} / \mathrm{m}^{2}$ immediately beneath the ice cover because of a reflection coefficient of 0.95 . In contrast, about $50 \mathrm{E} / \mathrm{m}^{2}$ entered the lake during the summer solstice of 1983 because on that day the reflection coeffi- cient was 0.10 and the PAR input was $55.8 \mathrm{E} / \mathrm{m}^{2}$.

Extinction coefficients at the east station ranged from 0.30 to 0.67 per meter (mean $=0.46, n=29$ ), whereas they ranged from 0.30 to 0.50 per meter (mean $=0.38$, $n=29$ ) at the west station. These values are characteristic of clear-water lakes according to Wetzel (1975). The higher coefficients tended to occur during iceout, when increased streamflows in Meadow Creek delivered suspended sediment to the lake. An additional influence during iceout may have been due to increased water color in Meadow Creek, which drains numerous muskegs that typically contain organically stained water. Extinction coefficients were also higher at both stations during the autumn, a time in which lake-bottom sediments were likely to be resuspended by water-column circulation. The differences in extinction coefficients between Big Lake's east and west stations were largely due to the isolation of the west basin from Meadow and Fish Creeks, both of which are located in the east basin. 

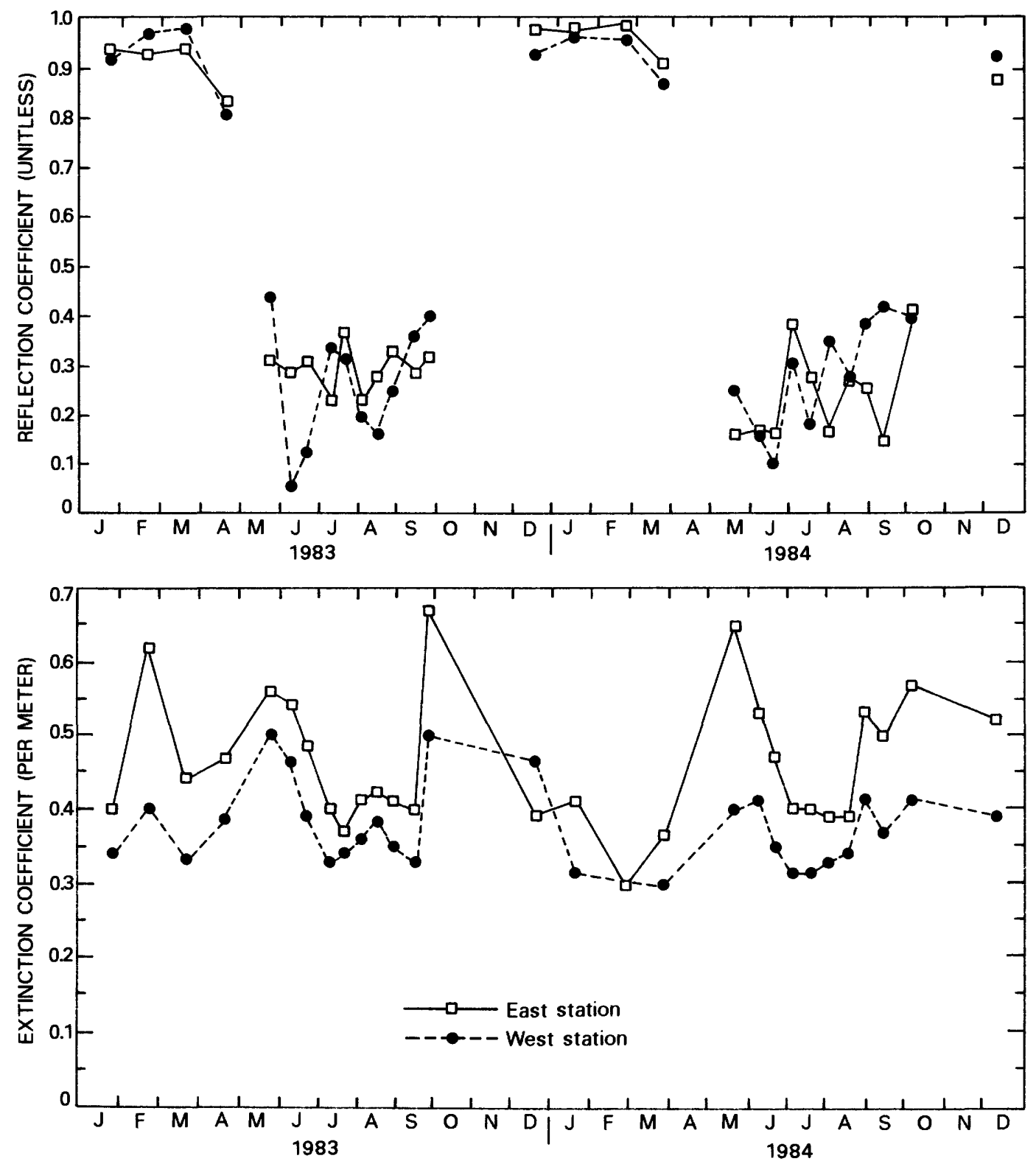

Figure 3.3. Extinction and reflection coefficients during 1983-84. 


\subsection{PHYSICAL LIMNOLOGY-Continued}

3.4 Euphotic Zone and Epilimnion Depths

\section{During the Summer, the Euphotic Zone at Each Limnological Station Was Frequently Deeper Than Its Associated Epilimnion}

The euphotic zone of the west station ranged from 2.2 to $15 \mathrm{~m}$, whereas that of the east station ranged from 1 to $11 \mathrm{~m}$. During the period of summer thermal stratification, the epilimnion depth ranged from 4 to $17 \mathrm{~m}$ at the west station and from 3.5 to $12.5 \mathrm{~m}$ at the east station.

The euphotic zone, defined here as that part of the water column in which in situ PAR is equal to or greater than 1 percent of the PAR incident on the lake's surface, ranged from 1 to $11 \mathrm{~m}$ at the east station and from 2.2 to $15 \mathrm{~m}$ at the west station (fig. 3.4). The deepest euphotic zones at both stations occurred in June and July, when extinction and reflection coefficients were low and the solar angle was near its yearly maximum. During the openwater season, the mean euphotic-zone depths were 9.7 and $12.5 \mathrm{~m}$, respectively, at the east and west stations. The deeper euphotic-zone depths for the west station were due largely to its lower extinction coefficients. The depth of the euphotic zone has often been estimated from secchidisc transparency measurements. During Big Lake's openwater season, secchi-disc transparencies ranged from 3.8 to $7.2 \mathrm{~m}$ (mean=5.7, $n=21)$ at the east station and from 4.0 to $9.4 \mathrm{~m}$ (mean=7.3, $n=19$ ) at the west station (fig. 3.4). The mean depth of the euphotic zone was found to be 1.7 times the mean secchi-disc transparencies for both stations. There was, however, considerable variation in the individual comparisons; thus, the prediction of Big Lake's euphotic-zone depths from its secchi-disc transparencies would be imprecise.

Also shown in figure 3.4 is the depth of the epilimnion. The lower depth limit of Big Lake's epilimnion was based on the depth of the thermocline, the point in the water column at which water temperatures decrease at a rate greater than $1^{\circ} \mathrm{C}$ per meter. The thermocline was nonexistent during full-depth lake circulation and when the lake was covered with ice. When the lake was thermally stratified, generally from late May into late September, the thermocline depth ranged from 3.5 to $12.5 \mathrm{~m}$ at the east station and from 4 to $17 \mathrm{~m}$ at the west station. An important feature of both stations was that the lower limit of the euphotic zone commonly was deeper than that of the epilimnion, often by as much as $5 \mathrm{~m}$. 


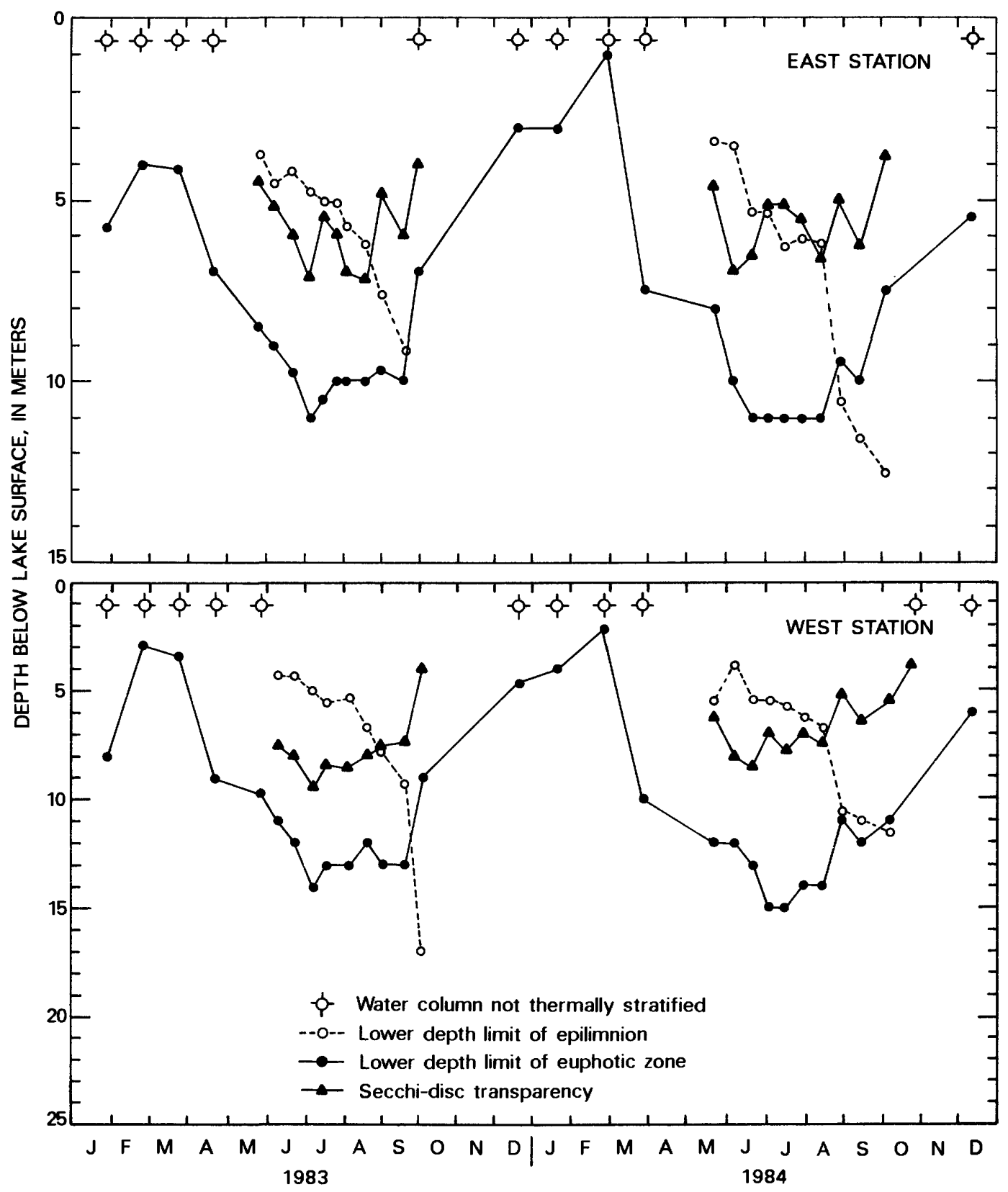

Figure 3.4. Depths of epilimnion and euphotic zone and water-column transparency. 


\subsection{PHYSICAL LIMNOLOGY-Continued}

\subsection{Water Temperature}

\subsubsection{East Station}

\section{Following Iceout in Late May, Thermal Stratification Developed Rapidly in Response to Warming Caused by 18 to 19.5 Hours of Daylength Available Within 1 Month of the Summer Solstice}

Big Lake was dimictic in both 1983 and 1984 in that full-depth circulation occurred in the spring and autumn. A well-developed thermocline existed during the summers of both years, with upper water-column temperatures between 18.0 and $18.7^{\circ} \mathrm{C}$.

The distribution of water temperatures with depth at the east station is shown in figure 3.5.1. The minimum temperatures under winter ice cover were less than $1^{\circ} \mathrm{C}$. After the ice cover melted in late May, the upper water column warmed rapidly in response to the 18 to 19.5 hours of daylength available from late May to the summer solstice. Temperatures exceeded $18^{\circ} \mathrm{C}$ for about 45 days in each year, and such temperatures extended to depths of 4 and $5.5 \mathrm{~m}$, respectively, in 1983 and 1984 . The maximum temperatures reached $18.7^{\circ} \mathrm{C}$ during early July and early August 1983 , and $18.5^{\circ} \mathrm{C}$ during mid-July and mid-August 1984. The upper part of the water column commenced cooling in mid-August, and ice re-formed in late October. Circulation of the water column was complete in the spring and autumn of both years; thus the east station was dimictic.

Thermal stratification was pronounced in the summer of both years. The thermocline, in the metalimnion, developed within a week of iceout. The thermocline in
1983 was developed more strongly than in 1984 on the basis of a comparison of maximum rates of temperature decline per meter. On July 6,1983 , a temperature of $18.7^{\circ} \mathrm{C}$ at $4 \mathrm{~m}$ overlaid a temperature of $12.9^{\circ} \mathrm{C}$ at $5 \mathrm{~m}$. The largest change in 1984 was observed on July 16, when the temperature between depths of 5.5 and $6.5 \mathrm{~m}$ dropped $4.5^{\circ} \mathrm{C}$. The depth of the thermocline during 1983 ranged from about $3.5 \mathrm{~m}$ (late May) to $9 \mathrm{~m}$ (late September); in 1984 the range was from about $3.5 \mathrm{~m}$ (late May) to $12.5 \mathrm{~m}$ (early October). Cooling and subsequent circulation of the water column during August and September deepened and weakened the thermocline until it ceased to exist in late September or early October. Inverse thermal stratification developed rapidly under the winter ice cover. Colder, less dense water overlies warmer, more dense water that is near the temperature of maximum density at about $4^{\circ} \mathrm{C}$ (see fig. 3.5.1). Bottom waters under ice cover retain heat from the bottom sediments. This inverse stratification was not disrupted until iceout occurred the following spring. 

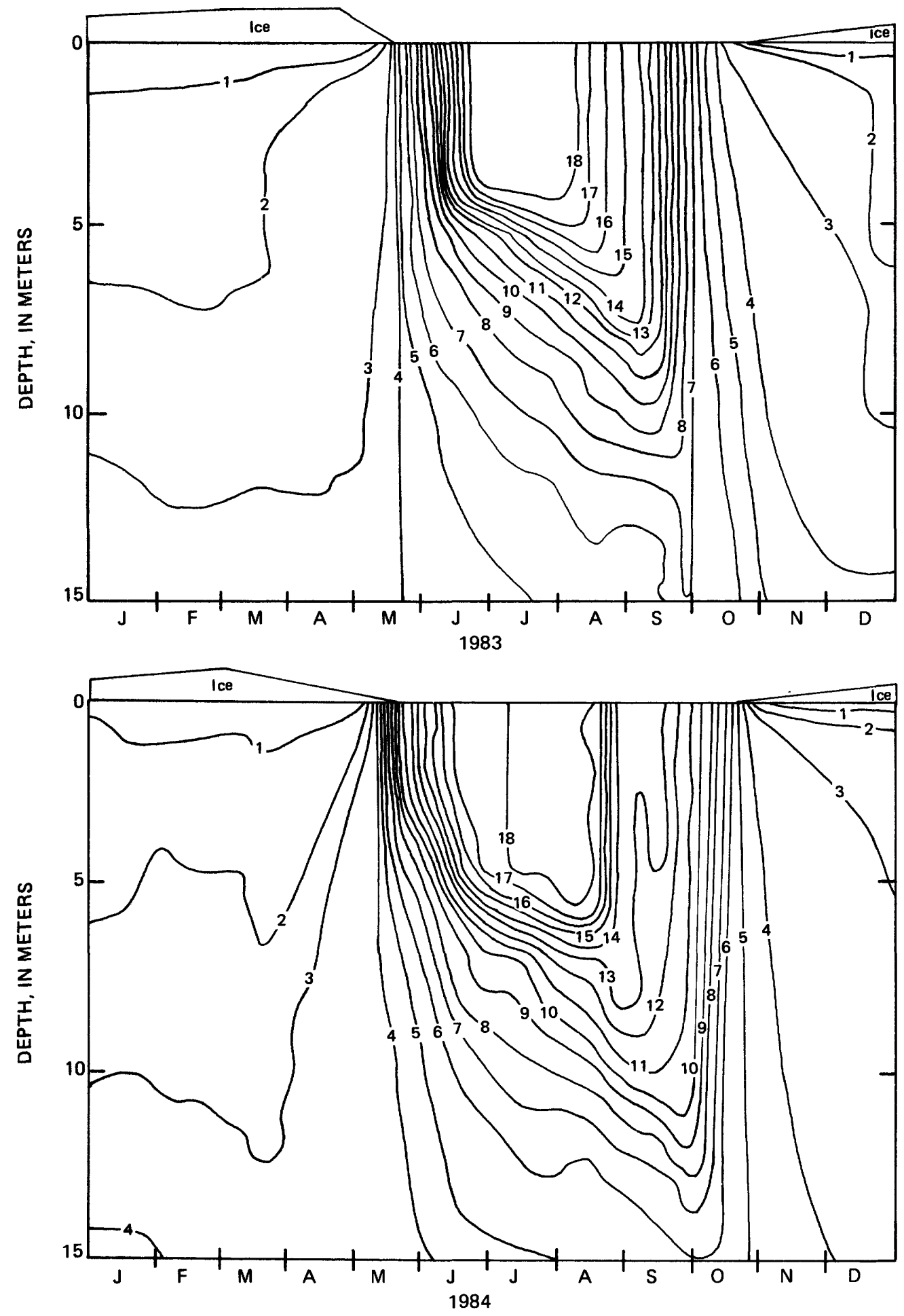

Figure 3.5.1. Lines of equal water temperatures (interval is $1^{\circ} \mathrm{C}$ ) at the east station. 


\subsection{PHYSICAL LIMNOLOGY-Continued}

\subsection{Water Temperature-Continued}

\subsubsection{West Station}

\section{Water Temperatures at West Station Reached Peaks Similar to Those at East Station But Did Not Persist as Long}

The pattern of water temperatures at the west station was similar to that at the east station, but the larger volume of cold hypolimnetic water at the west station delayed the development of near-surface temperatures higher than $18.0^{\circ} \mathrm{C}$.

The seasonal distribution of water temperatures with depth at the west station (fig. 3.5.2) was similar to that at the east station (fig. 3.5.1). The upper water column warmed rapidly after iceout, but peak temperatures were attained later and did not persist as long as they did at the east station. The lake at the west station is $10 \mathrm{~m}$ deeper than at the east station and thus can store a larger volume of cold, hypolimnetic water. The west station may also have been cooler than the east station because the latter is more directly influenced by surface runoff delivered from Meadow Creek. On only about 20 days (mid-July to early August) in 1983 and about 30 days (mid-July to mid-August) in 1984 did the west station have near-surface temperatures higher than $18^{\circ} \mathrm{C}$; the east station had about 45 days of such temperatures in each year. The west station reached a maximum temperature of $18.5^{\circ} \mathrm{C}$ in late July of both years. Full-depth circulation occurred in the spring and autumn of both years.

The water at the west station was thermally stratified from the first of June to early October in 1983 and from about May 22 to mid-October in 1984. The thermocline was most pronounced in early July of both years, with a temperature decline of about $6^{\circ} \mathrm{C}$ per meter between depths of 5 and $6 \mathrm{~m}$. The depth of the thermocline ranged from 4.2 to $16.5 \mathrm{~m}$ in 1983 and from 4 to $11.5 \mathrm{~m}$ in 1984. Inverse stratification developed but was not as strong as that found at the east station. 

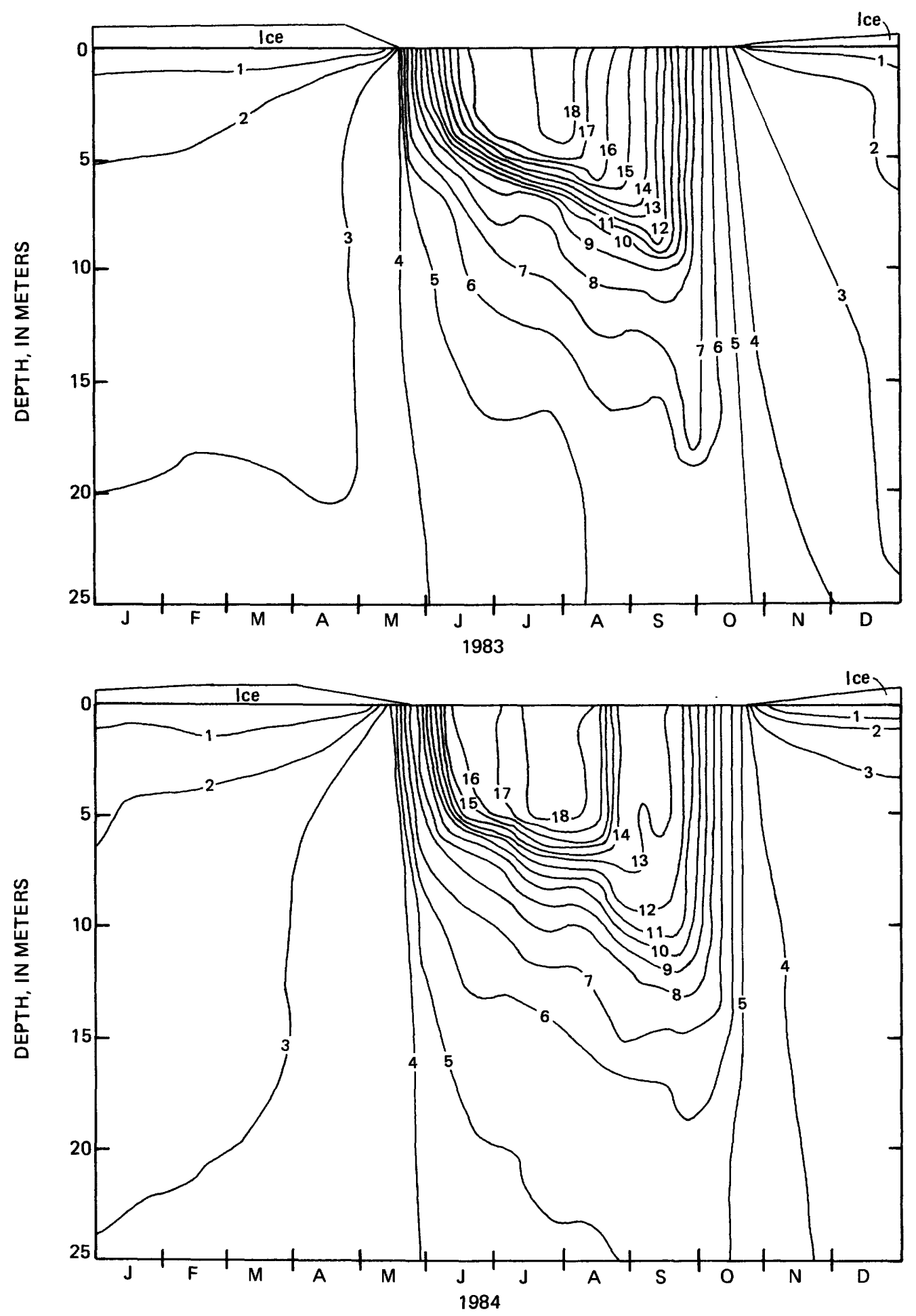

Figure 3.5.2. Lines of equal water temperatures (interval is $1^{\circ} \mathrm{C}$ ) at the west station. 


\title{
4.0 CHEMICAL LIMNOLOGY
}

\subsection{Major Cations and Anions}

\section{Waters of Big Lake Are of the Calcium Bicarbonate Type}

\begin{abstract}
Concentrations of major cations and anions and the alkalinity and hardness differed only slightly between near-surface and near-bottom samples taken on four occasions at each limnological station. Calcium was the dominant cation and bicarbonate was the principal anion.
\end{abstract}

The major cations $\left(\mathrm{Ca}^{2+}, \mathrm{K}^{+}, \mathrm{Mg}^{2+}, \mathrm{Na}^{+}\right)$and anions $\left(\mathrm{Cl}^{-}, \mathrm{HCO}_{3}^{-}, \mathrm{SO}_{4}^{2-}\right)$ were determined for both limnological stations from near-surface and near-bottom samples collected in May and September 1983 and March and May 1984. The range in concentrations, in milligrams per liter of the major cations and anions, was as follows: $\mathrm{Ca}^{2+}, 14$ to $22 ; \mathrm{K}^{+}, 0.1$ to $1.1 ; \mathrm{Mg}^{2+}, 2.4$ to $3.7 ; \mathrm{Na}^{+}, 1.9$ to $2.7 ; \mathrm{Cl}^{-}, 1.5$ to 2.1 ; $\mathrm{HCO}_{3}^{-}, 61$ to 93 ; and $\mathrm{SO}_{4}^{2-}, 1.7$ to 7.5 . There were only minor differences in the concentrations of near-surface and near-bottom samples. The concentrations of alkalinity (as
$\mathrm{CaCO}_{3}$ ) and hardness for both depths are shown in figure 4.1. The near-bottom samples had slightly higher concentrations than the near-surface samples. The concentrations of the cations and anions were converted to milliequivalents to determine the percentage contribution of each constituent. Calcium represented between 70 and 72 percent of the major cations, whereas magnesium contributed 18 to 21 percent. From 86 to 94 percent of the major anions were represented by bicarbonate. On the basis of these results, the waters of Big Lake are of the calcium bicarbonate type. 

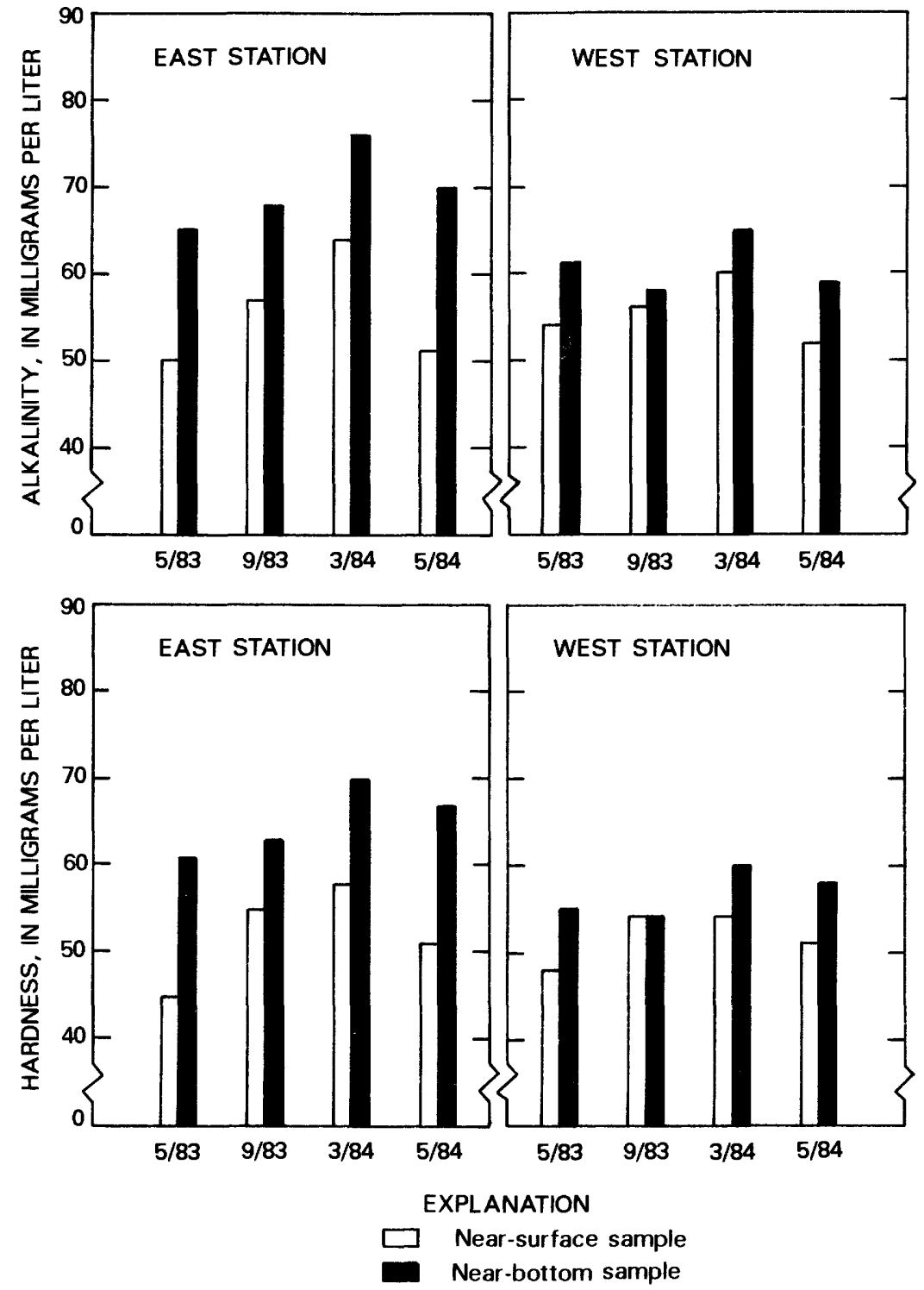

Figure 4.1. Variations in alkalinity and hardness. 


\title{
4.0 CHEMICAL LIMNOLOGY-Continued
}

\subsection{Specific Conductance}

\subsubsection{East Station}

\section{Specific Conductance Ranged From 94 to 161 Microsiemens; Highest Values Were Associated With Hypolimnetic Waters That Were Devoid of Dissolved Oxygen}

\begin{abstract}
Anoxic conditions near the lake bottom promoted release of dissolved constituents out of the lake sediments with a resultant rise in specific conductance of the overlying water. The highest specific conductances in each year occurred under such conditions.
\end{abstract}

Specific conductance was profiled as a measure of the variation in dissolved-solids concentration with depth and time in Big Lake. Specific conductance and dissolvedsolids concentration are commonly measured concurrently to determine the relation between the two variables. Hem (1985) reported that many natural waters without high concentrations of sulfate have dissolved-solids concentrations between 55 and 75 percent of their specificconductance values. The ratio of dissolved-solids concentration to specific conductance in Big Lake for the water-quality samples discussed in section 4.1 of this report ranged from 0.51 to 0.65 with a mean value of 0.59 .

The variation of specific conductance with depth and time at the east station is shown in figure 4.2.1. During 1983, specific conductance ranged from 94 to 138 $\mu \mathrm{S}$ and was usually stratified with depth. The lowest values occurred near middepth in late July. The highest values occurred near the bottom in March, April, August, and September, when dissolved oxygen was also absent near the bottom. Under these anoxic conditions, dissolved constituents are released from the lake sediments with resultant increases in dissolved-solids concentrations and specific conductance. The specific conductance of the upper water column tended to increase under the ice cover as a consequence of the freeze-out of dissolved constituents as ice formed (Canfield and others, 1983). When the lake's ice and snow cover melted in late May, there was a decrease in the specific conductance of the upper water column. The spring circulation period was brief and, as shown in figure 4.2.1, the $100-\mu \mathrm{S}$ line did not penetrate to the lake bottom. The autumn circulation period was of longer duration and was complete throughout the water column, as shown by the nearly vertical lines of equal concentration.

In 1984, specific conductance ranged from 109 to $161 \mu \mathrm{S}$, with the maximum values again occurring near the lake bottom during periods of anoxia. The lowest values occurred in the upper water column shortly after melting of the lake's ice and snow cover. The upper 10 $m$ of the water column had a narrower range in specific conductance during 1984 than in 1983; however, the stratification of specific conductance in the bottom $5 \mathrm{~m}$ of the lake was more pronounced in 1984 than in 1983. Water-column circulation, with respect to specific conductance, was incomplete in both the spring and autumn of 1984. 

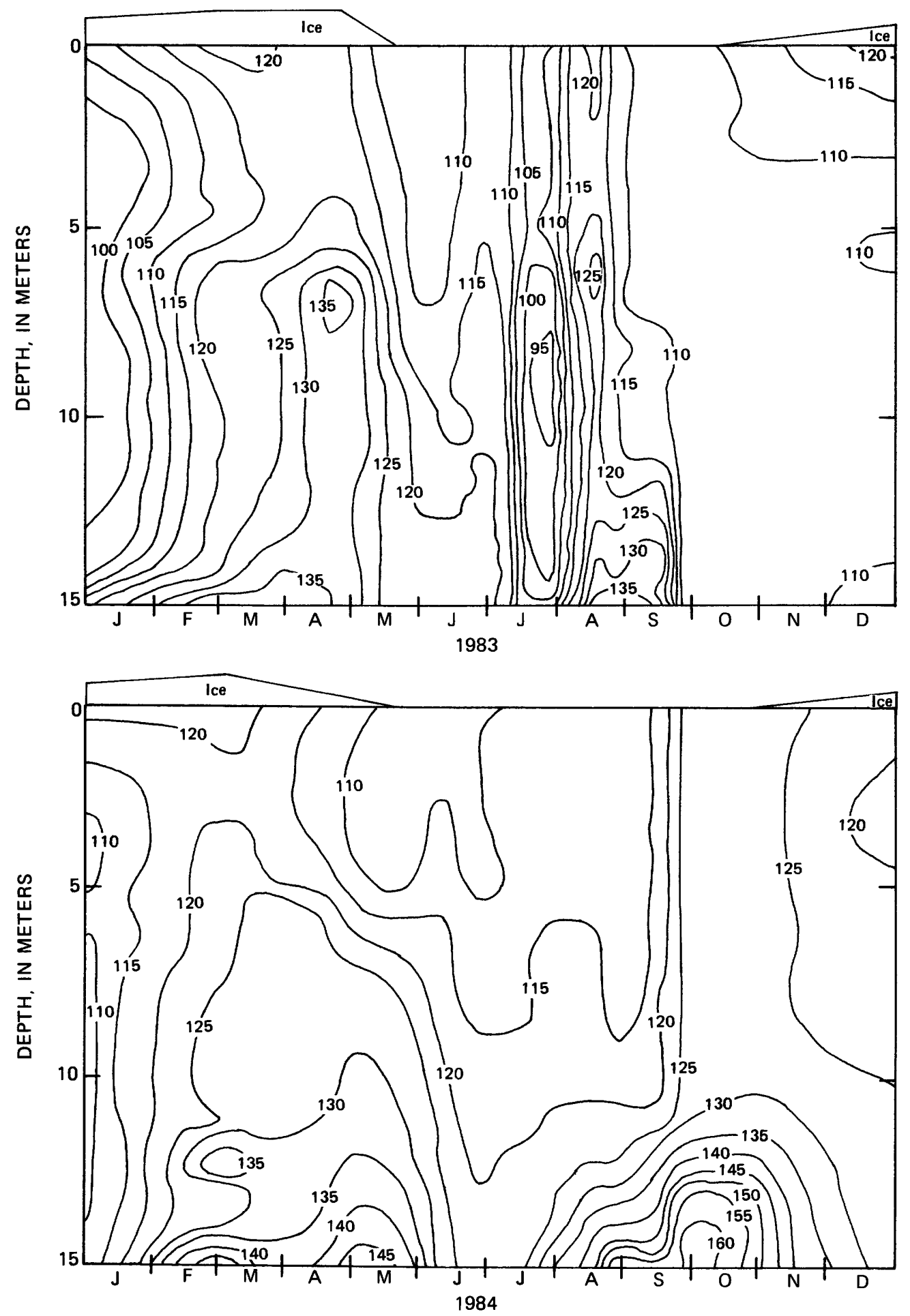

Figure 4.2.1. Lines of equal specific conductance (interval is $5 \mu \mathrm{S} / \mathrm{cm}$ at $25^{\circ} \mathrm{C}$ ) at the east station. 


\subsection{CHEMICAL LIMNOLOGY-Continued}

\subsection{Specific Conductance-Continued}

\subsubsection{West Station}

\section{West Station Had Smaller Range in Specific Conductance Than East Station But, as at East Station, Highest Values Were Within Anoxic Hypolimnion}

The range in specific conductance, in microsiemens, was 85 to 117 during 1983 and 105 to 120 in 1984 . The spring and autumn circulations produced nearly uniform distributions of specific conductance over the 25 -m-deep water column in both years.

Specific conductance at the west station ranged from 85 to $117 \mu \mathrm{S}$ during 1983 . There was some stratification of specific conductance with depth (fig. 4.2.2) but less than that at the east station during 1983 (fig. 4.2.1). The lowest values of specific conductance were within $5 \mathrm{~m}$ of the lake bottom in late July. The highest values were also near the lake bottom, but in April. As with the east station, the higher values of specific conductance occurred in conjunction with anoxic conditions. Following the melting of the ice cover in late May, water-column circulation was virtually complete with respect to specific conductance, in that it did not vary more than $5 \mu \mathrm{S}$ over the 25 -m-deep water column. The autumn period of water-column circulation resulted in an equal distribution of specific conductance with depth.

During 1984, specific conductance ranged from 105 to $120 \mu \mathrm{S}$ (fig. 4.2.2) and was less variable over depth and time than in 1983. The highest specific-conductance values were near the lake bottom in March, April, and late August, periods in which dissolved oxygen was absent near the lake bottom. The lowest values of specific conductance occurred in January in the lower half of the water column. As in 1983, specific conductance was nearly uniform with depth during the spring and autumn circulation periods.

Specific conductance at the east station was more stratified with depth than at the west station (figs. 4.2.1, 4.2.2). The autumn periods of water-column circulation in 1983 and 1984 produced nearly uniform specificconductance values over the full depths of both limnological stations; however, the east station failed to achieve such uniformity during the spring circulations of 1983 and 1984. The overall range in specific conductance for both stations and years was 85 to $161 \mu \mathrm{S}$, a range that would yield predicted dissolved-solids concentrations of 50 to $94 \mathrm{mg} / \mathrm{L}$ when based on the ratio of 0.59 reported in section 4.2 .1 of this report. 

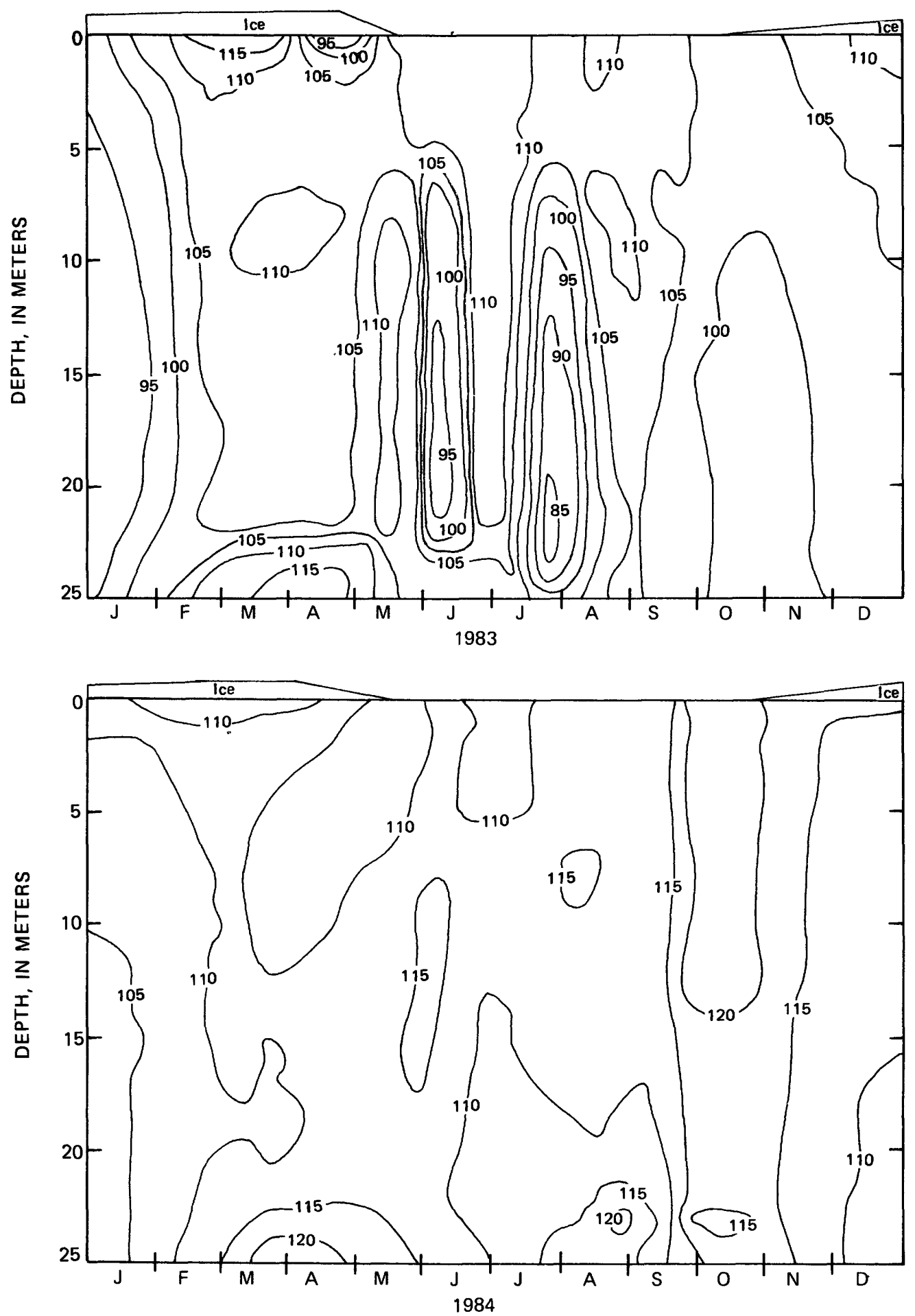

Figure 4.2.2. Lines of equal specific conductance (interval is $5 \mu \mathrm{S} / \mathrm{cm}$ at $25^{\circ} \mathrm{C}$ ) at the west station. 


\title{
4.0 CHEMICAL LIMNOLOGY-Continued
}

\subsection{Dissolved Oxygen}

\subsubsection{East Station}

\section{Dissolved-Oxygen Concentrations Ranged From 0 to 14.7 Milligrams Per Liter During 1983-84}

\begin{abstract}
Dissolved oxygen was distinctly stratified with depth during both years. The higher concentrations were in the upper euphotic zone, whereas the lowest concentrations were in the anoxic hypolimnion.
\end{abstract}

Dissolved-oxygen concentrations at the east station varied considerably during 1983 and were typically stratified with depth (fig. 4.3.1). The upper water column in December held the highest concentrations $(14.7 \mathrm{mg} / \mathrm{L})$, whereas anoxic conditions prevailed at or near the lake bottom for about 5 months. From mid-April until mid-May the lower one-third of the water column was devoid of dissolved oxygen. The circulation of the water column in late May only replenished dissolved-oxygen concentrations to $4 \mathrm{mg} / \mathrm{L}$ near the bottom. Thermal stratification during the summer resulted in a steady loss of dissolved oxygen throughout the lower depths because atmospheric reaeration of the hypolimnion was impeded by the wellestablished thermocline. By late July anoxia again prevailed near the bottom. Water-column circulation in late September replenished dissolved-oxygen concentrations to $10 \mathrm{mg} / \mathrm{L}$ down to the bottom. After the ice cover re- formed in late October, dissolved-oxygen concentrations began to decline again in the lower depths in response to the oxygen-consuming demands of respiration and decomposition and an absence of atmospheric reaeration. Throughout 1983 the upper half of the water column contained dissolved-oxygen concentrations in excess of 4.5 $\mathrm{mg} / \mathrm{L}$.

The range in dissolved-oxygen concentrations during 1984 was similar to that during 1983 , as was the overall trend with depth and time. Anoxic conditions near the lake bottom were of shorter duration in 1984 than in 1983 and did not extend as high into the water column. Spring reaeration was incomplete in 1984 , but the autumn circulation period was able to reaerate the full depth of the water column at the east station. The upper half of the water column had dissolved-oxygen concentrations higher than 5.5 $\mathrm{mg} / \mathrm{L}$ throughout 1984. 

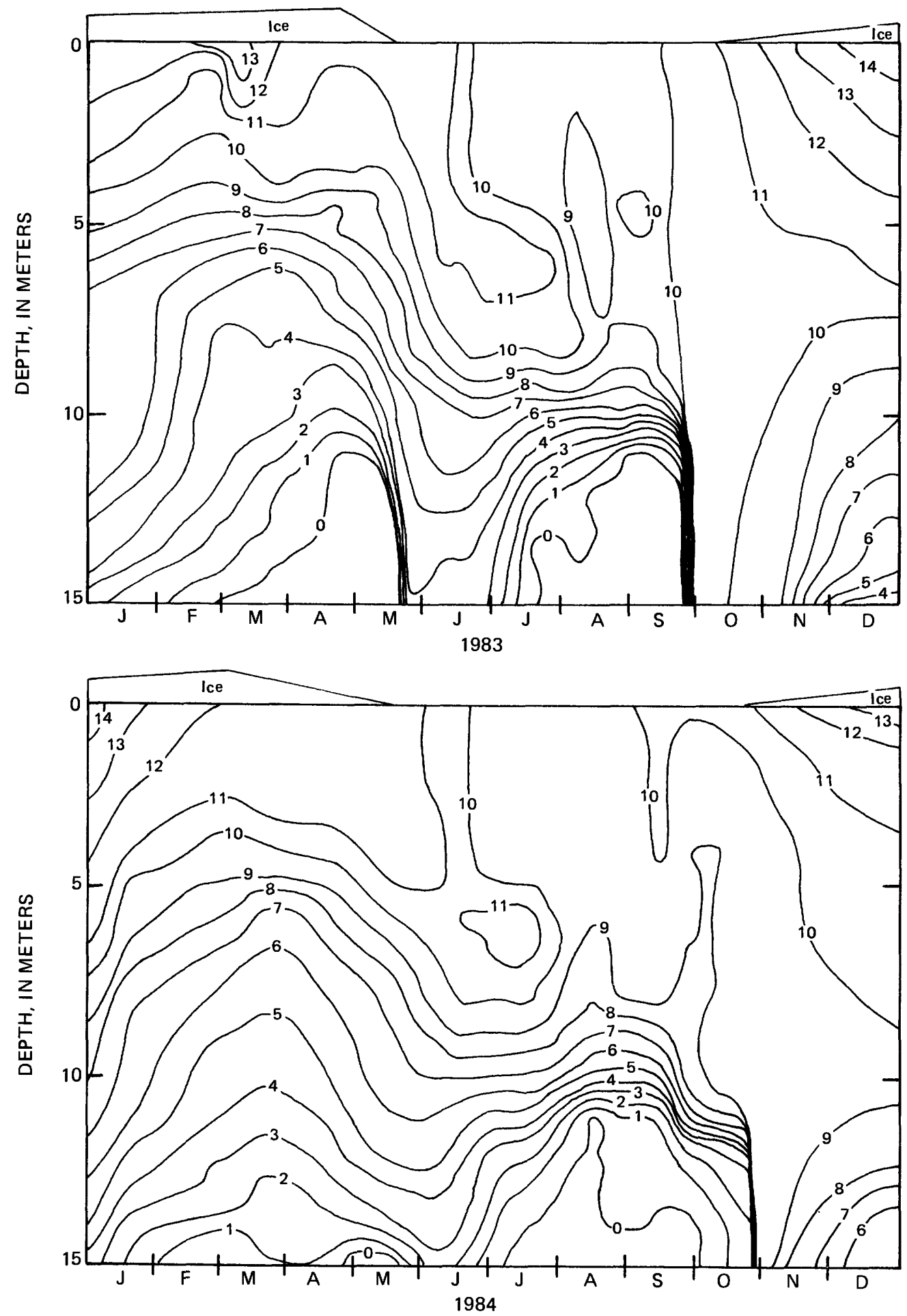

Figure 4.3.1. Lines of equal dissolved-oxygen concentrations (interval is $1 \mathrm{mg} / \mathrm{L}$ ) at the east station. 


\subsection{CHEMICAL LIMNOLOGY_Continued}

\subsection{Dissolved Oxygen-Continued}

\subsubsection{West Station}

\section{Dissolved-Oxygen Concentrations Ranged From 0 to 13.7 Milligrams Per Liter During 1983-84}

The full depth of the water column was not reaerated by the spring circulation; however, the autumn circulation restored dissolved oxygen throughout the $25-\mathrm{m}$-deep water column.

The dissolved-oxygen concentrations during 1983 at the west station ranged from 0.0 to $13.7 \mathrm{mg} / \mathrm{L}$ and, as at the east station, dissolved oxygen was stratified with depth except during water-column circulation in October (fig. 4.3.2). The highest concentrations occurred in December in the upper water column. Anoxic conditions were present near the lake bottom from April until late May. Watercolumn circulation in late May raised near-bottom dissolved-oxygen concentrations to about $5 \mathrm{mg} / \mathrm{L}$. These near-bottom concentrations declined to about $1.5 \mathrm{mg} / \mathrm{L}$ during the summer, but they were increased to $10 \mathrm{mg} / \mathrm{L}$ following a complete circulation of the water column in mid-October. The upper half of the 25-m-deep water column contained dissolved-oxygen concentrations higher than $5.5 \mathrm{mg} / \mathrm{L}$ during 1983 .

Dissolved-oxygen concentrations during 1984 ranged from 0.0 to $13.4 \mathrm{mg} / \mathrm{L}$ with the highest concentrations in January in the upper water column (fig. 4.3.2). The period of anoxia near the lake bottom shifted to August through October, although dissolved-oxygen concentrations of about $1.0 \mathrm{mg} / \mathrm{L}$ occurred near the bottom from mid-March to mid-May. As in 1983, the spring circulation failed to raise dissolved-oxygen concentrations to more than 6.5 $\mathrm{mg} / \mathrm{L}$ near the bottom. Water-column circulation in late October reaerated the entire water column to $10 \mathrm{mg} / \mathrm{L}$. During 1984, the upper half of the water column had dissolved-oxygen concentrations higher than $5.0 \mathrm{mg} / \mathrm{L}$.

Dissolved-oxygen concentrations at the east and west stations exhibited a wide range over depth and time during both years, but the general pattern in dissolvedoxygen concentrations was similar at the two limnological stations. An important feature was that water-column circulation in May was not able to reaerate the entire depth at each station, and thus their hypolimnia were deficient in dissolved oxygen at the onset of summer thermal stratification. A fully aerated water column was achieved only during the autumnal circulation of the lake. This condition was short lived, however, because dissolved-oxygen concentrations near the lake bottom declined rapidly under the winter ice cover. 

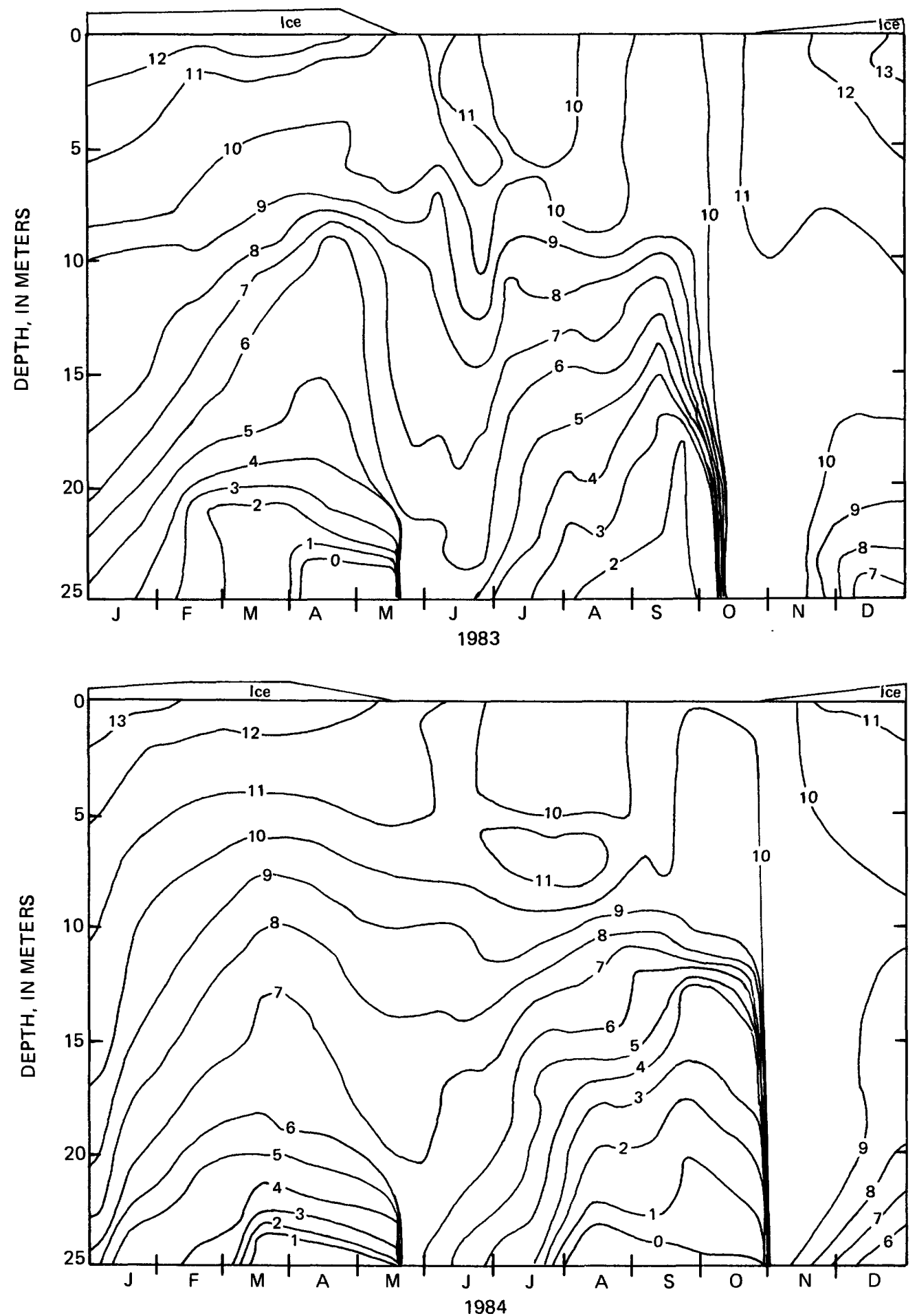

Figure 4.3.2. Lines of equal dissolved-oxygen concentrations (interval is $1 \mathrm{mg} / \mathrm{L}$ ) at the west station. 


\subsection{CHEMICAL LIMNOLOGY-Continued}

\subsection{Percent Saturation of Dissolved Oxygen}

\subsubsection{East Station}

\section{Percent Saturation of Dissolved Oxygen Varied From Anoxic to Supersaturated During 1983-84}

The highest percent saturations occurred in the upper euphotic zone during the summer; they reached 124 percent in 1983 and 114 percent in 1984.

The percent saturation of dissolved oxygen in Big Lake is affected by the interaction of four variables: dissolved-oxygen concentration, water temperature, barometric pressure, and salinity. Of these four, the effect of salinity can be disregarded because Big Lake is a freshwater lake. Saturation at the east station during 1983 ranged from 0 to 124 percent and was stratified with depth except during autumnal circulation of the water column (fig. 4.4.1). Saturations equal to or greater than 100 percent occurred in the upper water column from late May to late July as a result of atmospheric reaeration during spring circulation and photosynthetic production of oxygen by phytoplankton. The spring circulation failed to reaerate the entire water column, as evidenced by percent saturations of less than 60 percent in the lower $5 \mathrm{~m}$ of the east station. The near-bottom waters were typically very undersaturated with dissolved oxygen; they were anoxic ( 0 percent saturation) from March to mid-May and from late July to late September. The near-bottom waters had their highest percent saturation, about 85 , during water-column circulation in late September and early October.

The percent saturation of dissolved oxygen during 1984 ranged from 0 to 114 percent and was stratified with depth for most of the year (fig. 4.4.1). Only during autumnal circulation in late October did the entire water column have an equal percent saturation. Saturations equal to or greater than 100 percent occurred in the upper water column from late May to mid-August as well as in early January. Spring circulation failed to raise the percent saturation of the lower $5 \mathrm{~m}$ of the lake to more than 60 percent saturation. Near the lake bottom, percent saturation was 0 during parts of February, March, April, May, July, August, September, and October. 

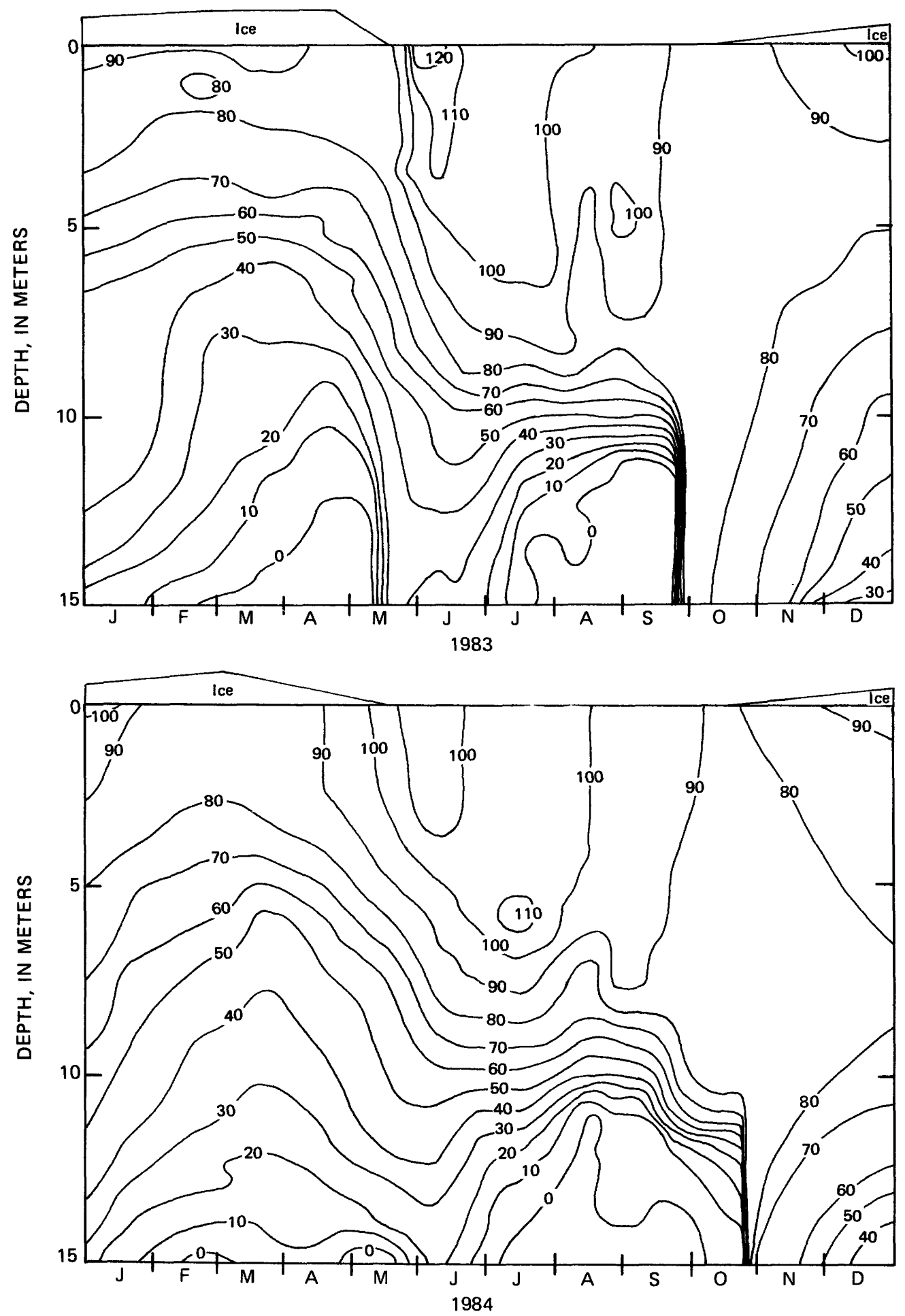

Figure 4.4.1. Lines of equal percent saturation of dissolved oxygen (interval is 10 percent) at the east station. 


\title{
4.0 CHEMICAL LIMNOLOGY-Continued
}

\subsection{Percent Saturation of Dissolved Oxygen-Continued}

\subsubsection{West Station}

\section{Percent Saturation of Dissolved Oxygen Varied From Anoxic to Supersaturated During 1983-84}

\begin{abstract}
Water-column circulation in the autumn of each year was only capable of producing 80 percent saturation over the entire depth.
\end{abstract}

The deeper west station also exhibited pronounced stratification of dissolved-oxygen percent saturation with depth during the 2-yr study (fig. 4.4.2). In 1983, saturation ranged from 0 to 114 percent, but the occurrence of anoxia was much less than at the east station. Although the nearbottom waters of the west station were typically undersaturated with dissolved oxygen, April was the only month with anoxic conditions. The spring circulation raised dissolvedoxygen saturation to about 50 percent in the lowermost $5 \mathrm{~m}$, whereas the autumnal circulation in mid-October achieved saturations of about 80 percent throughout the 25 -m-deep water column. Saturation values equal to or greater than 100 percent were limited to the upper water column during
June through August and were due largely to photosynthetic production of oxygen by phytoplankton.

In 1984, the distribution of percent saturation of dissolved oxygen was similar to that in 1983, except that anoxic conditions were present in August, September, and October in the lowermost depths. Neither the spring nor autumn circulation was able to reaerate the entire water column to 100 percent saturation, although the autumn circulation did produce saturations of about 80 percent over the entire depth. The upper water column contained in excess of 100 percent saturation during late May to late $\mathrm{Au}$ gust; the highest value, 117 percent, occurred in mid-July at about the 5-m depth. 

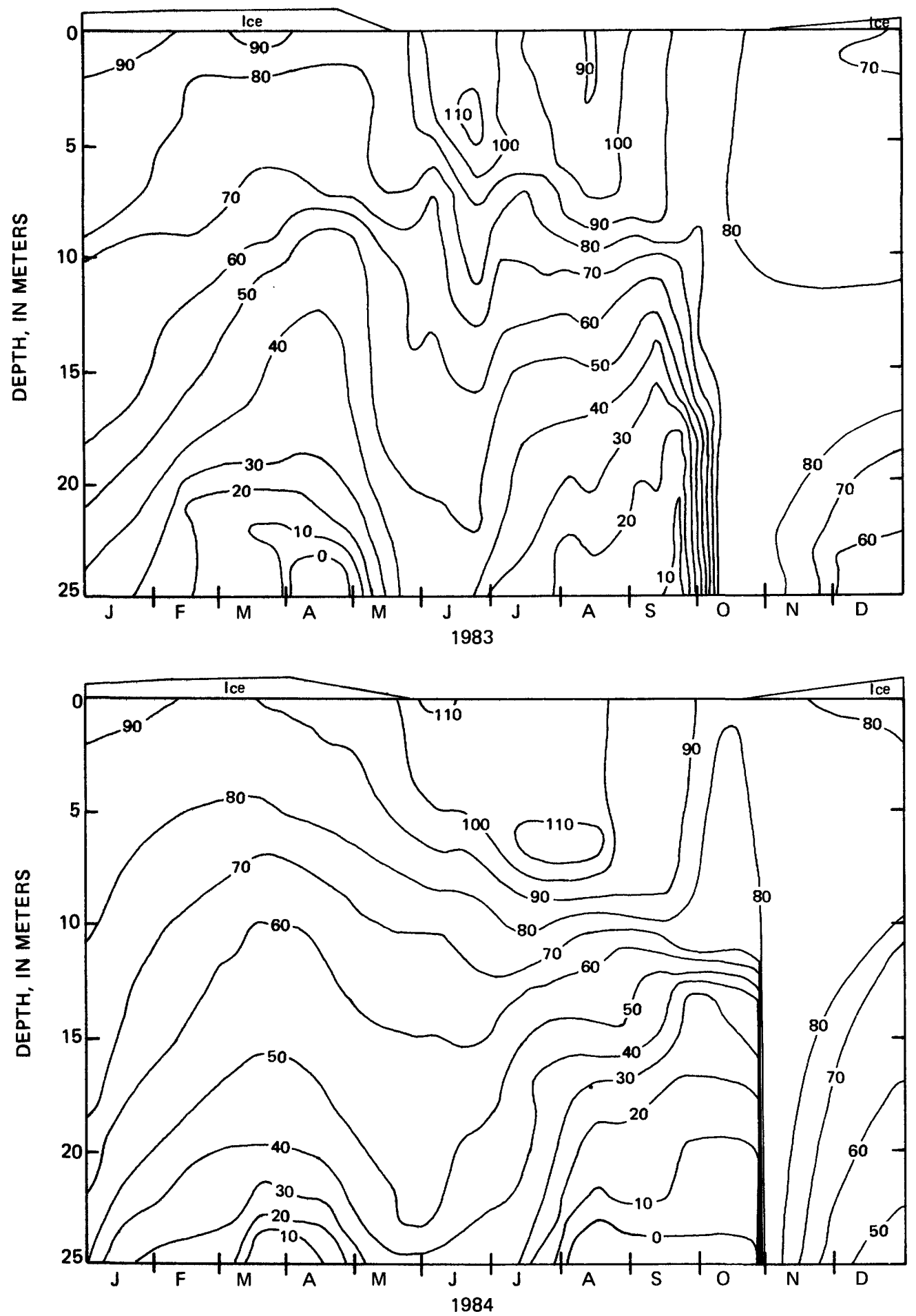

Figure 4.4.2. Lines of equal percent saturation of dissolved oxygen (interval is 10 percent) at the west station. 


\subsection{CHEMICAL LIMNOLOGY-Continued}

$4.5 \mathrm{pH}$

\subsubsection{East Station}

\section{Most of the Water Column Had Near-Neutral pH Through- out Much of 1983-84}

The range in $\mathrm{pH}$ during 1983-84 was from 6.2 to 7.6 . Lower values occurred within the anoxic hypolimnion as well as in the epilimnion.

A measure of the acidity or basicity of water is indicated by $\mathrm{pH}$, a water-quality variable that represents the negative base-10 logarithm of the hydrogen ion activity in moles per liter (Hem, 1985). The overall range of $\mathrm{pH}$ for dilute solutions is 0 to 14 . Acidic waters are those with a $\mathrm{pH}$ less than 7.0; $\mathrm{pH}$ values larger than 7.0 represent basic waters. Most open-water lakes in which bicarbonate is the dominant anion have pH's that range from 6 to 9 (Wetzel, 1975).

The east station of Big Lake had $\mathrm{pH}$ values that ranged from 6.2 to 7.6 during 1983 (fig. 4.5.1). Acidic conditions in the hypolimnion coincided with low dissolved-oxygen concentrations. The lowering of $\mathrm{pH}$ in the hypolimnion occurs as carbon dioxide is increased as a result of several processes: respiration, decomposition, microbial methane fermentation, nitrification of ammonia, and oxidation of sulfide (Wetzel, 1975). The lowest $\mathrm{pH}, 6.2$, occurred during October and November within the epilimnion and during formation of ice cover. The highest $\mathrm{pH}, 7.6$, was found in the upper water column during June and July, when photosynthesis by phytoplankton apparently removed carbon dioxide more rapidly than it was being produced by respiration, decomposition, and atmospheric reaeration. Stratification of $\mathrm{pH}$ was most evident in mid-August, when the upper third of the water column had a $\mathrm{pH}$ of 7.4 while the hypolimnion had pH's as low as 6.4. By late September, the circulation of the water column had produced a range of $\mathrm{pH}$ from 7.0 to 7.2 for the entire water column.

In 1984, $\mathrm{pH}$ ranged from 6.2 to 7.2 (fig. 4.5.1). The incidence of pH's less than 7.0 was higher than in 1983, even though 1983 had a more severe depletion of dissolved oxygen in the hypolimnion. As in 1983, the lowest pH's for 1984 were measured in the anoxic hypolimnion in late August and early September. The highest pH's, 7.2, were not exclusively associated with peak photosynthesis in the upper euphotic zone during the summer; much of the water column during November and December had pH's of 7.2. 

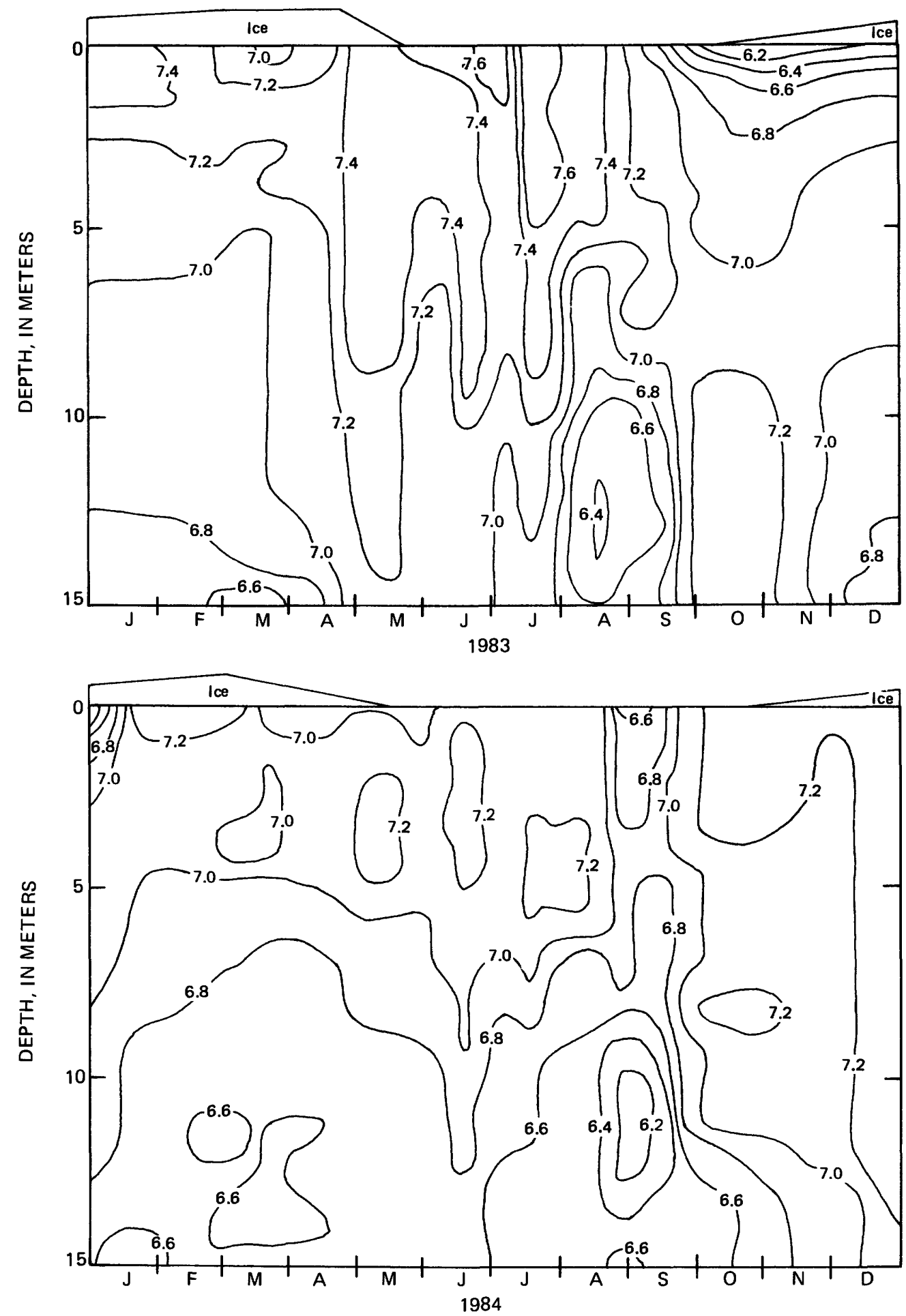

Figure 4.5.1. Lines of equal $\mathrm{pH}$ (interval is 0.2 standard units) at the east station. 


\subsection{CHEMICAL LIMNOLOGY-Continued}

\section{$4.5 \mathrm{pH}-$ Continued}

\subsubsection{West Station}

\section{pH Ranged From 6.4 to 8.0 During 1983-84}

Stratification of $\mathrm{pH}$ was most pronounced when anoxic conditions in the hypolimnion produced a lowering of $\mathrm{pH}$ while the upper water column increased in $\mathrm{pH}$ in response to photosynthetic activity of phytoplankton.

Most of the water column at the west station had $\mathrm{pH}$ 's higher than 7.0 during 1983; the overall range in $\mathrm{pH}$, was from 6.4 to 8.0 (fig. 4.5.2). The lowest $\mathrm{pH}$ 's occurred in the anoxic hypolimnion during September, whereas the highest $\mathrm{pH}$ 's were in the upper euphotic zone in May and June. The stratification of $\mathrm{pH}$ over depth was well developed during July through September, but water-column circulation in early October resulted in a $\mathrm{pH}$ of 7.0 throughout the 25 -m-deep water column.

The range in $\mathrm{pH}$ during 1984 was 6.4 to 7.6 and was slightly less than that of 1983 (fig. 4.5.2). Stratification of pH was also less pronounced in 1984, but pH's less than 7.0 were more common than in 1983. As in 1983, the low- est pH's were in the anoxic hypolimnion in late summer. The highest $\mathrm{pH}$ 's were again within the upper euphotic zone, but in 1984 they occurred from late July to early August.

The overall pattern in $\mathrm{pH}$ at both stations during 1983 and 1984 fits that described for many lakes. The summer euphotic zone increased in $\mathrm{pH}$ in apparent response to photosynthetic utilization of carbon dioxide, whereas the $\mathrm{pH}$ in the hypolimnion decreased as carbon dioxide was added by various chemical and biological processes. The range of $\mathrm{pH}$ in Big Lake, 6.2 to 8.0, was within the normal range of open-water lakes. Most of Big Lake's water column was close to a neutral $\mathrm{pH}$ of 7.0 throughout most of each year. 

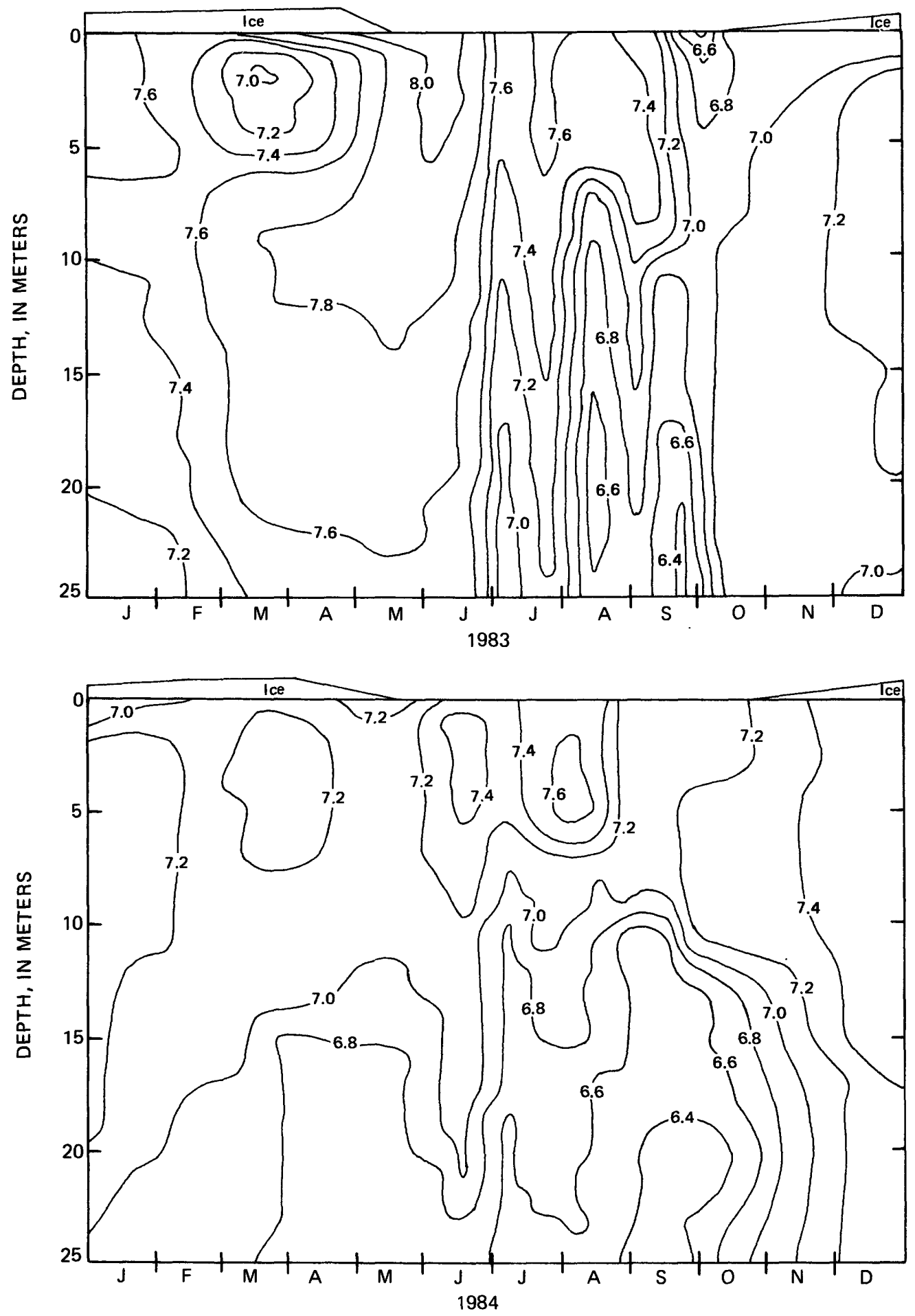

Figure 4.5.2. Lines of equal $\mathrm{pH}$ (interval is 0.2 standard units) at the west station. 


\title{
4.0 CHEMICAL LIMNOLOGY-Continued
}

\subsection{Phosphorus}

\subsubsection{Total Phosphorus \\ 4.6.1.1 East Station \\ Largest Concentrations of Total Phosphorus Were Associ- ated With Anoxic Hypolimnetic Water Near Lake Bottom}

\begin{abstract}
Development of anoxic conditions near the lake bottom produced total-phosphorus concentrations as high as $173 \mu \mathrm{g} / \mathrm{L}$ within the hypolimnion. In contrast, the upper part of the water column had total-phosphorus concentrations as low as $6 \mu \mathrm{g} / \mathrm{L}$.
\end{abstract}

Phosphorus analyses are commonly included in limnological studies because phosphorus is an essential nutrient in the metabolism of aquatic plants. Lake-eutrophication research has focused heavily on phosphorus because it is the nutrient typically found to have the smallest supply-todemand ratio for aquatic plant growth.

Phosphorus concentrations in Big Lake are reported here as total phosphorus and dissolved orthophosphate. Total-phosphorus concentrations represent the phosphorus in solution, associated with colloidal material, and contained in or attached to biotic and abiotic particulate material. The dissolved concentrations are determined from the filtrate that passes through a filter with a nominal pore size of $0.45 \mu \mathrm{m}$; thus, dissolved orthophosphate represents the orthophosphate in solution and associated with colloidal material capable of passing through a $0.45-\mu \mathrm{m}$ pore.

Total-phosphorus concentrations at the east station ranged from 6 to $80 \mu \mathrm{g} / \mathrm{L}$ during 1983 (fig. 4.6.1.1). Concentrations larger than $30 \mu \mathrm{g} / \mathrm{L}$ occurred near the lake bottom during August and September in conjunction with anoxic hypolimnetic water. Reoxygenation of the water column in early October yielded total-phosphorus concentrations of less than $15 \mu \mathrm{g} / \mathrm{L}$ throughout the water column. The smallest concentrations of total phosphorus were measured in the upper $5 \mathrm{~m}$ of the lake during June through August and in December.

In 1984, total-phosphorus concentrations were less than $10 \mu \mathrm{g} / \mathrm{L}$ in the upper water column from January through July and in December (fig. 4.6.1.1). The anoxic water near the lake bottom from mid-July through September had totalphosphorus concentrations as high as $173 \mu \mathrm{g} / \mathrm{L}$.

A statistical summary of total phosphorus concentrations, in micrograms per liter, measured during 1983 and 1984 is listed below for four depth strata at the east station.

The elevated total-phosphorus concentrations that were measured in the anoxic hypolimnion during 1983 and 1984 were attributable to conditions caused by the welldeveloped thermal stratification at the east station. Thermal stratification restricted vertical circulation of the water column and thereby allowed sestonic material to settle through the metalimnion into the hypolimnion. Seston consists of refractory and labile components that are differentially susceptible to decomposition into a dissolved form. Therefore, both the particulate and dissolved components that make up the total concentration of a constituent are affected by the input of seston to the hypolimnion. Thermal stratification also reduced the atmospheric reaeration of the water column. Anoxic conditions developed in the east station's hypolimnion when the dissolved oxygen near the lake bottom had been consumed by biochemical processes. Under these anoxic conditions, constituents such as phosphorus, ammonia, iron, and manganese within the bottom sediment may become mobilized and released into the overlying water as dissolved constituents. Thus, the net effect of well-developed thermal stratification and an anoxic hypolimnion was to increase the total (particulate plus dissolved) concentration of phosphorus within the hypolimnion of the east station.

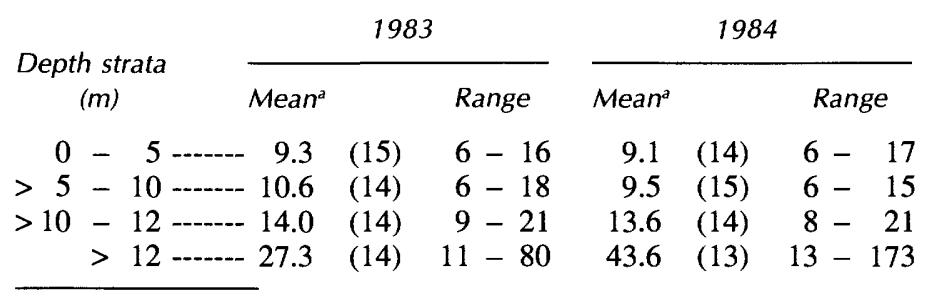

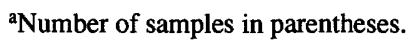



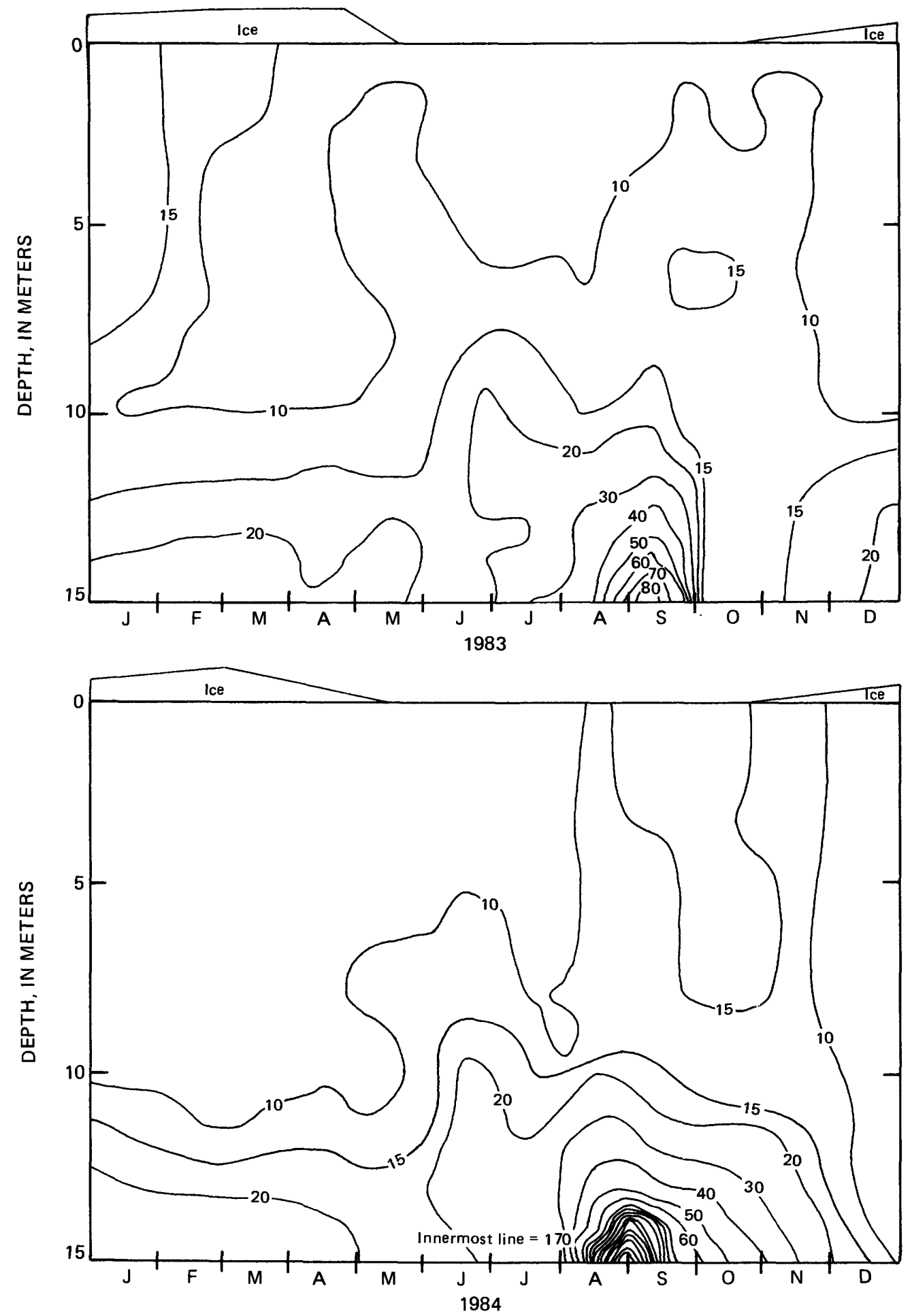

Figure 4.6.1.1. Lines of equal total-phosphorus concentrations (interval is 5 and $10 \mu \mathrm{g} / \mathrm{L}$ ) at the east station. 


\subsection{CHEMICAL LIMNOLOGY-Continued}

4.6 Phosphorus-Continued

4.6.1 Total Phosphorus-Continued

4.6.1.2 West Station

\section{Peak Concentrations of Total Phosphorus at West Station Were Substantially Less Than Those Measured at East Station in 1983 and 1984}

Development of anoxic hypolimnetic water was substantially reduced at the west station in comparison with the east station. As a result, peak total-phosphorus concentrations were about 40 percent of those measured at the east station.

Total-phosphorus concentrations in 1983 ranged from 6 to $32 \mu \mathrm{g} / \mathrm{L}$, with the largest concentrations near the lake bottom in late July and early August (fig. 4.6.1.2). The hypolimnion of the west station did not become anoxic during summer thermal stratification; thus, its totalphosphorus concentrations were not as enriched as those at the east station in 1983. The smallest concentrations occurred in the upper water column from August through December.
The range in total-phosphorus concentrations for 1984 was 6 to $72 \mu \mathrm{g} / \mathrm{L}$ (fig. 4.6.1.2). Anoxic conditions did develop in the hypolimnion during August through October and served to increase total-phosphorus concentrations by movement of dissolved and colloidal phosphorus out of the bottom sediments. The total-phosphorus concentrations, in micrograms per liter, measured in four depth strata are statistically summarized below for 1983 and 1984 at the west station.

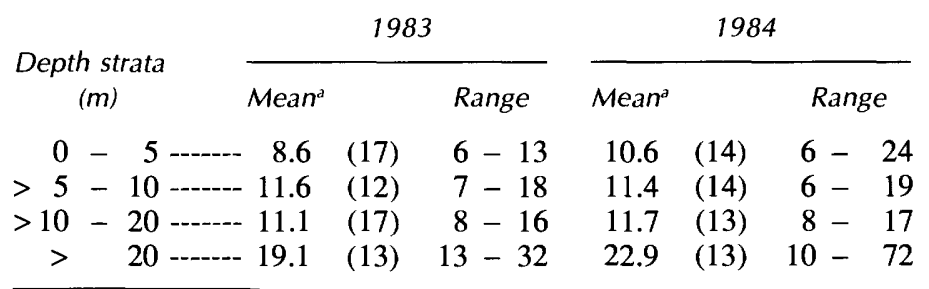

${ }^{\text {a} N u m b e r ~ o f ~ s a m p l e s ~ i n ~ p a r e n t h e s e s . ~}$ 

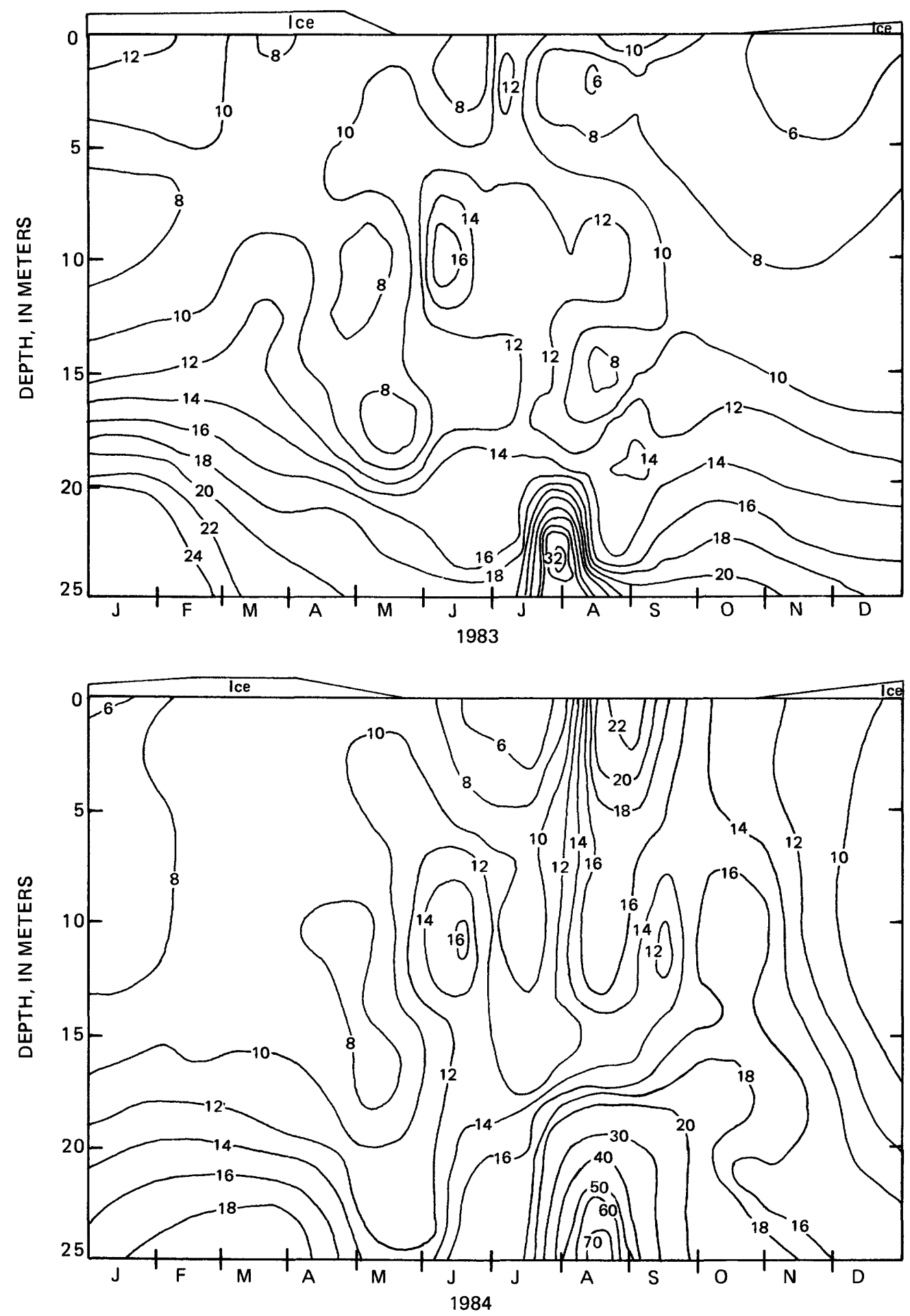

Figure 4.6.1.2. Lines of equal total-phosphorus concentrations (interval is 2 and $10 \mu \mathrm{g} / \mathrm{L}$ ) at the west station. 


\title{
4.0 CHEMICAL LIMNOLOGY-Continued
}

4.6 Phosphorus-Continued

\subsubsection{Dissolved Orthophosphate}

\author{
4.6.2.1 East Station
}

\section{Dissolved-Orthophosphate Concentrations, in Micrograms Per Liter, Within Epilimnion Ranged From 1 to 8 During 1983 Through 1984}

Phytoplanktonic uptake of dissolved orthophosphate reduced epilimnetic concentrations to less than $2 \mu \mathrm{g} / \mathrm{L}$ during the summer. Anoxic conditions within the hypolimnion produced dissolved-orthophosphate concentrations as high as $66 \mu \mathrm{g} / \mathrm{L}$ during the summer.

The orthophosphate ion, $\mathrm{PO}_{4}^{3-}$, is the most important form of phosphorus directly available for metabolic use by aquatic plants. The concentrations of dissolved orthophosphate reported here represent orthophosphate in solution and associated with colloidal material.

Dissolved-orthophosphate concentrations during 1983 ranged from 1 to $58 \mu \mathrm{g} / \mathrm{L}$ (fig. 4.6.2.1), with concentrations less than $2 \mu \mathrm{g} / \mathrm{L}$ occurring from March into September in water less than $10 \mathrm{~m}$ deep. Anoxic water near the lake bottom yielded concentrations higher than $10 \mu \mathrm{g} / \mathrm{L}$ during August and September, but watercolumn circulation in early October returned concentra- tions to less than $6 \mu \mathrm{g} / \mathrm{L}$.

During 1984 the range in dissolved-orthophosphate concentrations ( 1 to $66 \mu \mathrm{g} / \mathrm{L}$ ) was similar to that of 1983 (fig. 4.6.2.1). The epilimnion again had the lowest concentrations, which persisted from April through November. The lowermost hypolimnetic water was anoxic from mid-July through September and contained dissolvedorthophosphate concentrations up to $66 \mu \mathrm{g} / \mathrm{L}$.

Dissolved-orthophosphate concentrations, in micrograms per liter, measured during 1983 and 1984 are statistically summarized below for the four depth strata at the east station.

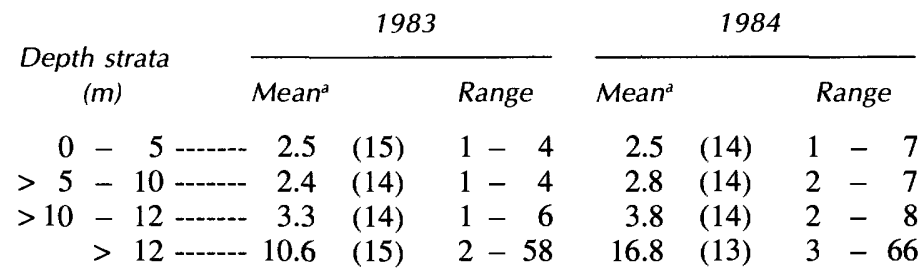

aNumber of samples in parentheses. 

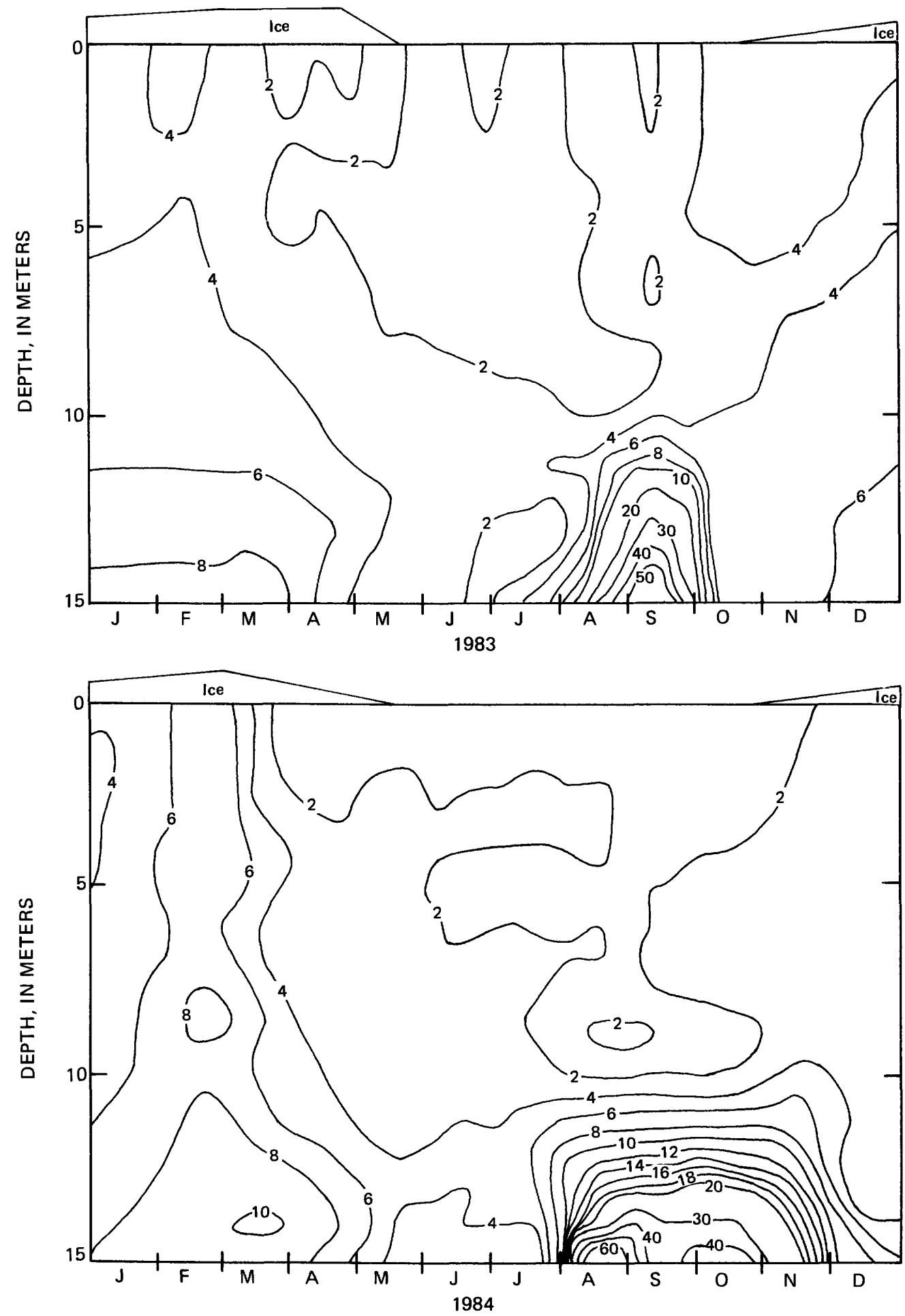

Figure 4.6.2.1. Lines of equal dissolved-orthophosphate concentrations (interval is 2 and 10 $\mu \mathrm{g} / \mathrm{L})$ at the east station. 


\subsection{CHEMICAL. LIMNOLOGY-Continued}

4.6 Phosphorus-Continued

4.6.2 Dissolved Orthophosphate-Continued

4.6.2.2 West Station

\section{Epilimnetic Concentrations of Dissolved Orthophosphate Ranged From 1 to 7 Micrograms Per Liter During 1983 Through 1984}

Peak concentrations of dissolved orthophosphate at the west station were only about onefourth as large as those measured at the east station. This was largely attributable to the near-absence of anoxic conditions at the west station.

The west station in 1983 contained dissolvedorthophosphate concentrations between 1 and $18 \mu \mathrm{g} / \mathrm{L}$ (fig. 4.6.2.2). Concentrations tended to be stratified with depth, especially during early spring and then again in late summer and early autumn. The lowest dissolvedorthophosphate concentrations occurred in the epilimnion during June through October. The largest concentrations were measured near the bottom in late July and early August in conjunction with dissolved-oxygen concentrations less than $2 \mu \mathrm{g} / \mathrm{L}$. Dissolved-orthophosphate concentrations up to $14 \mu \mathrm{g} / \mathrm{L}$ were measured near the bottom during January through mid-April.
The range in dissolved-orthophosphate concentrations during 1984 was 1 to $17 \mu \mathrm{g} / \mathrm{L}$ (fig. 4.6.2.2), but the largest concentrations were measured near the bottom during January to mid-March. The lowermost part of the hypolimnion became anoxic during August through October and yielded dissolved-orthophosphate concentrations as high as $14 \mu \mathrm{g} / \mathrm{L}$. As in 1983, the lowest concentrations were measured in the epilimnion during April through October.

A statistical summary of dissolved-orthophosphate concentrations, in micrograms per liter, measured during 1983 and 1984 is presented below for four depth strata at the west station.

\begin{tabular}{|c|c|c|c|c|c|c|c|c|}
\hline \multirow{2}{*}{\multicolumn{2}{|c|}{$\begin{array}{c}\text { Depth strata } \\
\text { (m) }\end{array}$}} & \multicolumn{3}{|c|}{1983} & \multicolumn{4}{|c|}{1984} \\
\hline & & \multicolumn{2}{|c|}{ Mean $^{a}$} & Range & \multicolumn{2}{|l|}{ Mean ${ }^{a}$} & \multicolumn{2}{|c|}{ Range } \\
\hline 0 & -5 & 2.7 & (18) & $1-5$ & 2.5 & (14) & $1-$ & 6 \\
\hline$>5$ & -10 & 2.8 & (12) & $2-6$ & 2.9 & (14) & $1-$ & 7 \\
\hline \multirow[t]{2}{*}{$>10$} & -20 & 5.0 & (17) & $2-14$ & 4.6 & (14) & 2 & 12 \\
\hline & $>20$. & 10.2 & (13) & $2-18$ & 10.0 & (14) & 2 & 17 \\
\hline
\end{tabular}

aNumber of samples in parentheses. 

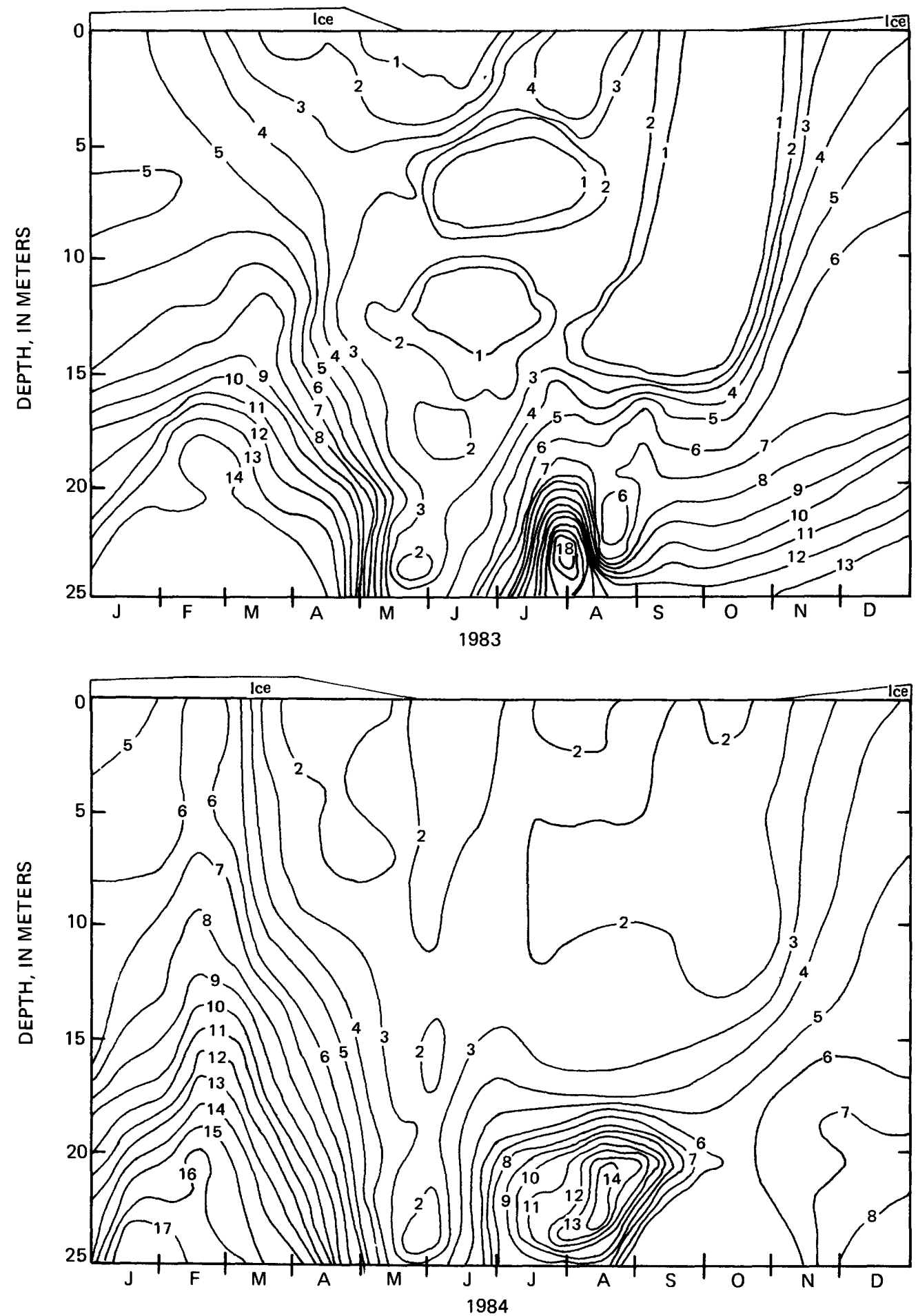

Figure 4.6.2.2. Lines of equal dissolved orthophosphate concentrations (interval is $1 \mu \mathrm{g} / \mathrm{L}$ ) at the west station. 


\title{
4.0 CHEMICAL LIMNOLOGY-Continued
}

\subsection{Nitrogen}

4.7.1 Total Ammonia Plus Organic Nitrogen

\subsubsection{East Station}

\section{Anoxic Near-Bottom Water Contained Largest Concentra- tions of Total Ammonia Plus Organic Nitrogen During 1983-84}

\begin{abstract}
Production of ammonia by heterotrophic decomposition of organic matter served to elevate concentrations of total ammonia plus organic nitrogen in the hypolimnion. However, water-column circulations in May and October produced nearly uniform and relatively low concentrations.
\end{abstract}

Nitrogen, like phosphorus, is a significant variable in many limnological studies because it is an important constituent of the protoplasm of aquatic biota. Nitrogen's supply-to-demand ratio is small; thus, nitrogen may limit the growth of aquatic plants as phosphorus does. The dynamics of nitrogen cycling in aquatic ecosystems are complex because most processes involving nitrogen are biologically mediated. In aquatic ecosystems, nitrogen commonly occurs in the following forms: dissolved molecular nitrogen $\left(\mathrm{N}_{2}\right)$, nitrogen-containing organic compounds, ammonia $\left(\mathrm{NH}_{3}\right)$, ammonium $\left(\mathrm{NH}_{4}^{+}\right)$, nitrite $\left(\mathrm{NO}_{2}^{-}\right)$, and nitrate $\left(\mathrm{NO}_{3}^{-}\right)$.

Nitrogen concentrations in Big Lake are reported here as total ammonia plus organic nitrogen (often called Kjeldahl nitrogen), dissolved ammonia, and dissolved nitrite plus nitrate. Total ammonia plus organic nitrogen concentrations represent the ammonia and organic nitrogen compounds in solution, associated with colloidal material, and contained in biotic and abiotic particulate material. The dissolved concentrations are determined from the filtrate that passes through a filter with a nominal pore size of $0.45 \mu \mathrm{m}$ and thus represent the ammonia or nitrite plus nitrate in solution and associated with colloidal material capable of passing through a $0.45-\mu \mathrm{m}$ pore.

Total ammonia plus organic nitrogen concentrations ranged from 130 to $400 \mu \mathrm{g} / \mathrm{L}$ during 1983 (fig. 4.7.1.1). The lowest concentrations were measured under ice cover during January through March and coincided with cold water temperatures and minimal amounts of photosynthetically active radiation, a condition that resulted in low rates of biological production and decomposition. Upper epilimnial concentrations showed a pulse as high as $350 \mu \mathrm{g} / \mathrm{L}$ during late June to early July. The pulse was likely caused by a buildup of particulatebound nitrogen associated with phytoplanktonic produc- tion of organic matter. A similar pulse occurred near the lake bottom in August and September, but the cause of this pulse differed from that for the epilimnial pulse. During August and September, the lower hypolimnion became anoxic and allowed substantial production of ammonia via heterotrophic decomposition of organic material (ammonification) in the hypolimnion and the bottom sediment. Reaeration of the water column in late September reduced hypolimnetic concentrations of total ammonia plus organic nitrogen to less than $200 \mu \mathrm{g} / \mathrm{L}$. By mid-November, concentrations began to increase as sestonic material settled through the water column following formation of the lake's ice cover. An earlier occurrence of anoxic bottom water during March through mid-May did not yield elevated concentrations of total ammonia plus organic nitrogen because low water temperatures substantially reduced ammonification rates.

In 1984, total ammonia plus organic nitrogen concentrations ranged from 150 to $940 \mu \mathrm{g} / \mathrm{L}$ (fig. 4.7.1.1), with two periods showing elevated concentrations. During the first 5 months, near-bottom concentrations exceeded $350 \mu \mathrm{g} / \mathrm{L}$ and were generally associated with dissolvedoxygen concentrations less than $2 \mathrm{mg} / \mathrm{L}$. Reaeration of the water column in late May produced near-bottom concentrations less than $250 \mu \mathrm{g} / \mathrm{L}$. The development of anoxic hypolimnetic conditions during July through September produced total ammonia plus organic nitrogen concentrations as high as $940 \mu \mathrm{g} / \mathrm{L}$ near the bottom. Epilimnial concentrations did not exceed $300 \mu \mathrm{g} / \mathrm{L}$ during 1984; the highest value was measured in September, whereas the lowest value occurred in February.

A statistical summary of total ammonia plus organic nitrogen concentrations, in micrograms per liter, measured during 1983 and 1984 is presented on the facing page for four depth strata at the east station. 


\begin{tabular}{|c|c|c|c|c|c|c|c|}
\hline \multirow{2}{*}{\multicolumn{2}{|c|}{$\begin{array}{c}\text { Depth strata } \\
\text { (m) }\end{array}$}} & \multicolumn{3}{|c|}{1983} & \multicolumn{3}{|c|}{1984} \\
\hline & & Mean & & Range & Mean $^{a}$ & & Range \\
\hline 0 & -5 & -207.3 & (15) & $170-370$ & 207.1 & (14) & $160-300$ \\
\hline & -10 & -192.9 & (14) & $130-230$ & 199.7 & (15) & $150-290$ \\
\hline \multirow[t]{2}{*}{$>10$} & -12 & -201.4 & (14) & $130-290$ & 230.2 & (14) & $160-270$ \\
\hline & $>12$ & -250.0 & (14) & $160-360$ & 432.7 & (13) & $220-940$ \\
\hline
\end{tabular}

${ }^{\text {a}}$ Number of samples in parentheses.
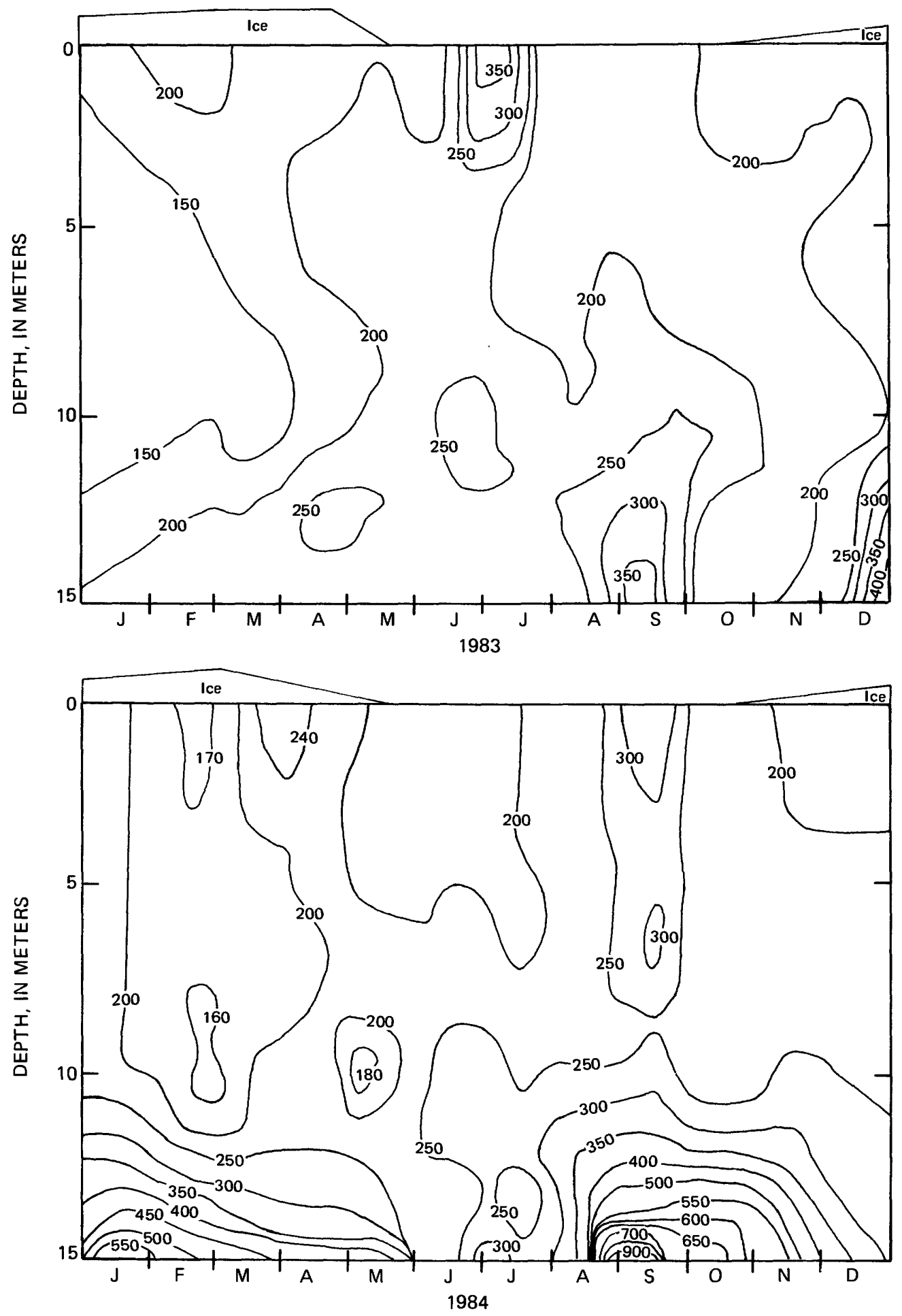

Figure 4.7.1.1. Lines of equal total ammonia plus organic nitrogen concentrations (interval, in micrograms per liter, is variable) at the east station. 


\subsection{CHEMICAL LIMNOLOGY-Continued}

\subsection{Nitrogen-Continued}

4.7.1 Total Ammonia Plus Organic Nitrogen-Continued

4.7.1.2 West Station

\section{Total Ammonia Plus Organic Nitrogen Concentrations Ranged From 110 to $\mathbf{4 0 0}$ Micrograms Per Liter During 1983-84}

Peak concentrations of total ammonia plus organic nitrogen were similar at the east and west stations during 1983, but not so for 1984. Peak concentrations in both years occurred near the lake bottom.

Concentrations of total ammonia plus organic nitrogen ranged from 110 to $400 \mu \mathrm{g} / \mathrm{L}$ during 1983 (fig. 4.7.1.2), with the highest concentrations measured near the lake bottom during January to late April. Circulation and reaeration in late May produced nearly uniform concentrations of total ammonia plus organic nitrogen throughout the water column. During summer stratification the west station did not become anoxic; however, concentrations of total ammonia plus organic nitrogen near the bottom during this period were nearly as high as those measured at the east station during the same period. Similar to the east station, the epilimnion showed an increase in total ammonia plus organic nitrogen concentrations during the summer as a result of photosynthetic production of organic matter. The stratification in concentrations between the epilimnion and hypolimnion was eliminated by autumnal circulation and reaeration, so that concentrations at the onset of ice cover were about $175 \mu \mathrm{g} / \mathrm{L}$ throughout the water column.

In 1984, the range in concentrations for total ammonia plus organic nitrogen was 130 to $360 \mu \mathrm{g} / \mathrm{L}$ (fig. 4.7.1.2). The lowest concentrations were measured during March near middepth. Unlike 1983, there was no buildup of total ammonia plus organic nitrogen near the lake bottom during ice cover, although near-bottom dissolved-oxygen concentrations in early 1984 were as low as $1 \mathrm{mg} / \mathrm{L}$. From late July to mid-September the nearbottom water had total ammonia plus organic nitrogen concentrations up to $360 \mu \mathrm{g} / \mathrm{L}$ in response to anoxic conditions. However, autumnal circulation produced nearly uniform concentrations of about $200 \mu \mathrm{g} / \mathrm{L}$.

A statistical summary of total ammonia plus organic nitrogen concentrations, in micrograms per liter, measured during 1983 and 1984 is listed below for four depth strata at the west station.

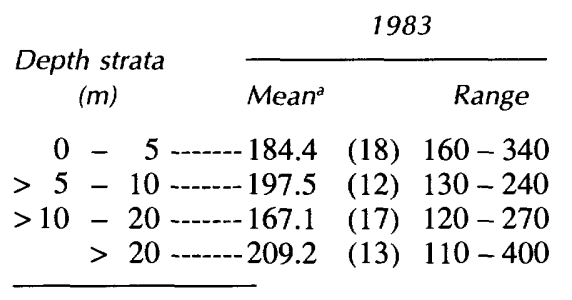

aNumber of samples in parentheses.

\begin{tabular}{lcc}
\multicolumn{2}{c}{1984} \\
\hline Mean $^{a}$ & \multicolumn{2}{c}{ Range } \\
204.3 & $(14)$ & $160-280$ \\
200.9 & $(14)$ & $140-290$ \\
189.4 & $(14)$ & $140-270$ \\
215.2 & $(14)$ & $130-360$
\end{tabular}



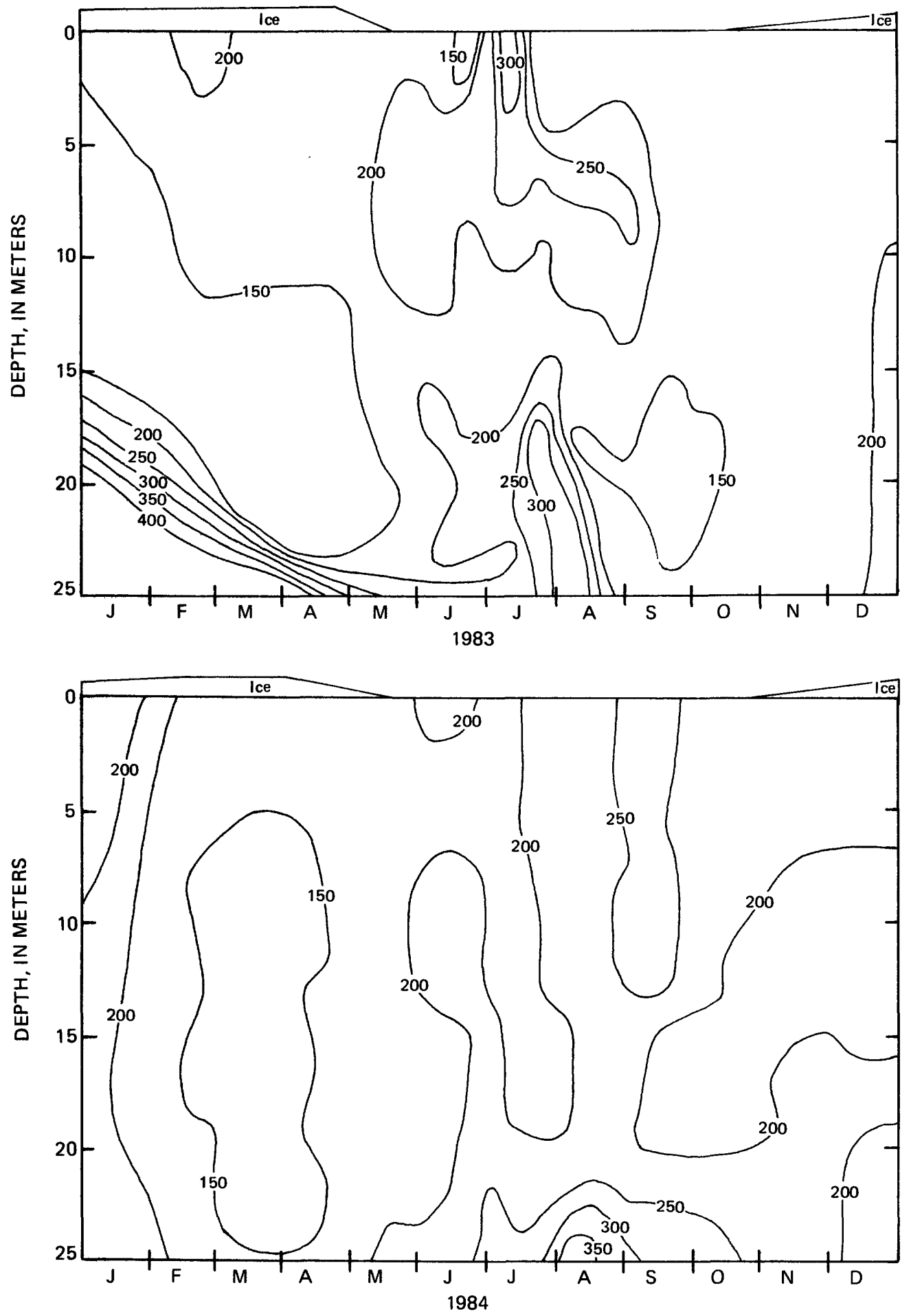

Figure 4.7.1.2. Lines of equal total ammonia plus organic nitrogen concentrations (interval is $50 \mu \mathrm{g} / \mathrm{L})$ at the west station. 


\title{
4.0 CHEMICAL LIMNOLOGY_Continued
}

\subsection{Nitrogen-Continued}

\subsubsection{Dissolved Ammonia}

\subsubsection{East Station}

\section{Metabolic Activity of Phytoplankton Reduced Summertime Concentrations of Dissolved Ammonia to Less Than 5 Micrograms Per Liter}

\begin{abstract}
Ammonification increased dissolved-ammonia concentrations to as much as $502 \mu \mathrm{g} / \mathrm{L}$ in the hypolimnion. In contrast, concentrations less than $1 \mu \mathrm{g} / \mathrm{L}$ resulted from assimilation of ammonia by phytoplankton within the upper water column during the summer.
\end{abstract}

Dissolved-ammonia concentrations during 1983 ranged from 2 to $104 \mu \mathrm{g} / \mathrm{L}$ (fig. 4.7.2.1). Concentrations less than $5 \mu \mathrm{g} / \mathrm{L}$ were measured in the upper water column during April through July and reflected uptake of ammonia by the metabolic activity of phytoplankton. Dissolved-ammonia concentrations were greater than 10 $\mu \mathrm{g} / \mathrm{L}$ ihroughout the year at depths below $10 \mathrm{~m}$. The highest concentrations occurred near the bottom during January into April and from mid-August through December in conjunction with very low dissolved-oxygen concentrations. Under such conditions, ammonia concentrations increased in response to heterotrophic decomposition of organic matter (ammonification) in the lower hypolimnion and within the bottom sediments.

During 1984, dissolved-ammonia concentrations ranged from less than 1 to $502 \mu \mathrm{g} / \mathrm{L}$ (fig. 4.7.2.1). Concentrations near the lake bottom were substantially higher than those measured in 1983. The elevated concentrations were associated with dissolved-oxygen concentrations less than $2 \mathrm{mg} / \mathrm{L}$. Dissolved-ammonia concentrations less than $10 \mu \mathrm{g} / \mathrm{L}$ were measured in water less than $10 \mathrm{~m}$ deep during most of the year.

Listed below is a statistical summary of dissolved ammonia concentrations, in micrograms per liter, measured during 1983 and 1984 within four depth strata at the east station.

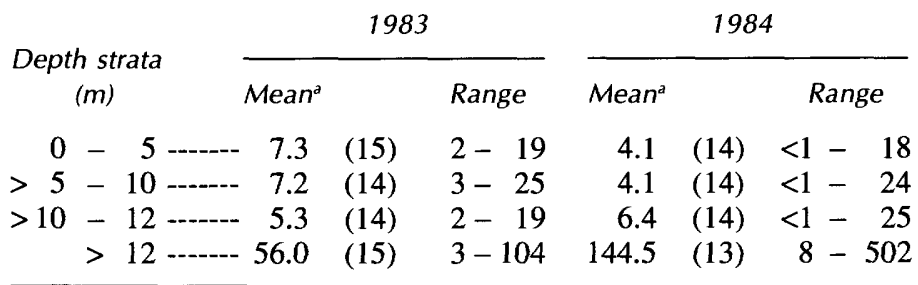

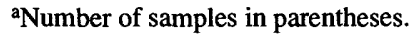



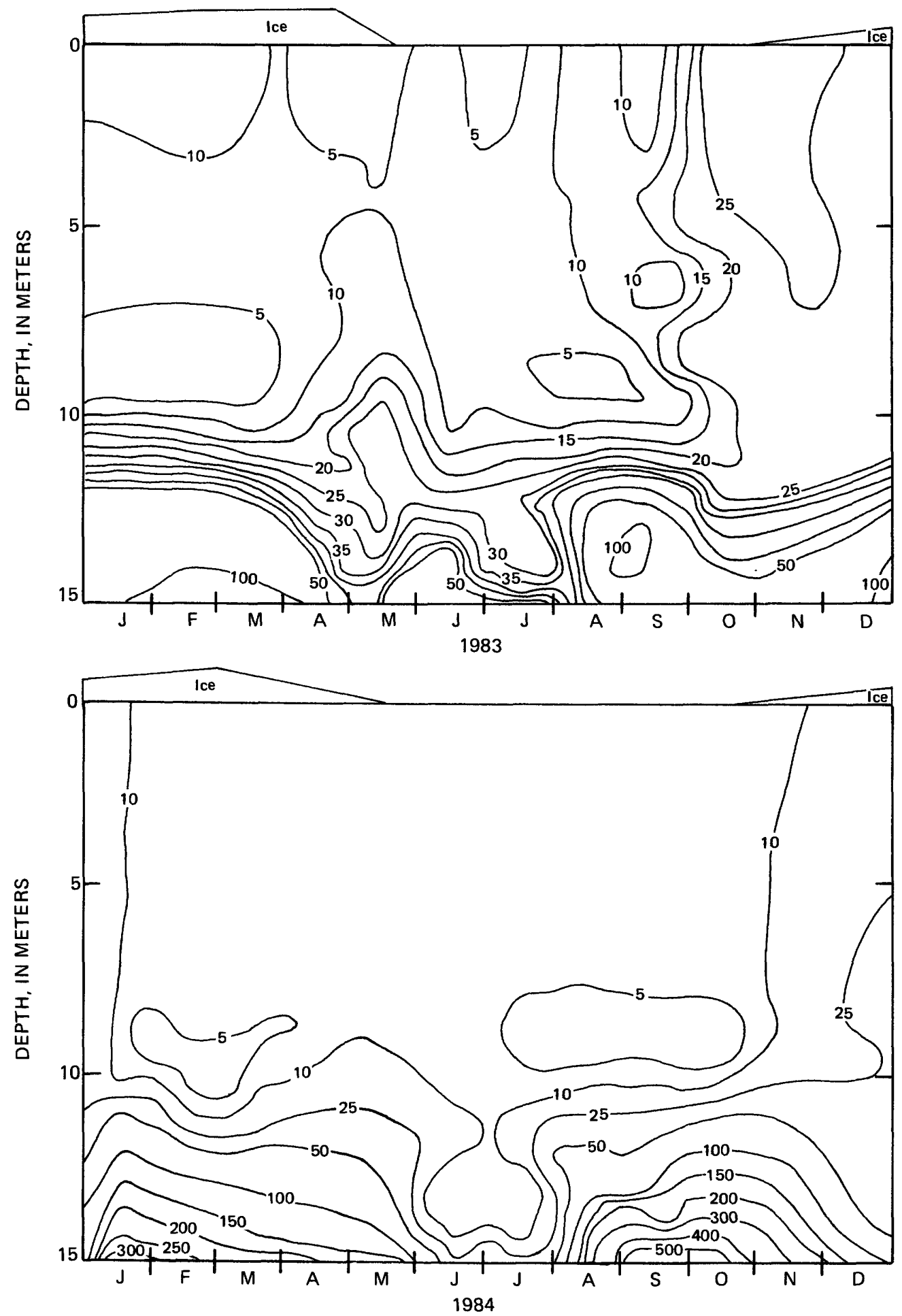

Figure 4.7.2.1. Lines of equal dissolved-ammonia concentrations (interval, in micrograms per liter, is variable) at the east station. 


\title{
4.0 CHEMICAL LIMNOLOGY-Continued
}

\subsection{Nitrogen-Continued}

\subsubsection{Dissolved Ammonia-Continued}

\subsubsection{West Station}

\section{Aerobic Conditions Facilitated Rapid Conversion of Ammo- nia to Nitrate By Nitrification Reactions}

\begin{abstract}
Because dissolved-oxygen depletion was less severe than at the east station, the west station did not show pronounced stratification of dissolved-ammonia concentrations. Peak concentrations were measured in the hypolimnion, whereas minimum concentrations tended to occur within the epilimnion.
\end{abstract}

The range in dissolved-ammonia concentrations during 1983 was 1 to $80 \mu \mathrm{g} / \mathrm{L}$ (fig. 4.7.2.2), which was slightly less than the range reported for the east station in 1983. The largest concentrations occurred from midJuly to mid-August in near-bottom water with dissolvedoxygen concentrations between 1 and $3 \mathrm{mg} / \mathrm{L}$. An earlier occurrence of low dissolved-oxygen concentrations near the bottom during April and May did not yield elevated dissolved-ammonia concentrations, probably because nitrification reactions were rapidly converting ammonia (the first product of aerobic heterotrophic decomposition) to nitrite and nitrate. Dissolved-ammonia concentrations less than $5 \mu \mathrm{g} / \mathrm{L}$ were measured throughout the water column during much of the year; the lowest concentrations occurred within the epilimnion during August and September. In contrast to the east station, dissolved ammonia was much less stratified with depth at the west station than at the east station, largely because dissolved- oxygen depletion was less severe at the west station.

In 1984, dissolved-ammonia concentrations ranged from less than 1 to $58 \mu \mathrm{g} / \mathrm{L}$ (fig. 4.7.2.2), which was substantially less than the $502-\mu \mathrm{g} / \mathrm{L}$ range reported for the east station for 1984. The incidence of dissolvedoxygen concentrations less than $1 \mathrm{mg} / \mathrm{L}$ was limited to two periods: March to mid-May and August through October. Nitrification of ammonia to nitrite and nitrate was thus given a favorable aerobic environment in the nearbottom water; this circumstance accounts for the low concentrations of dissolved ammonia in the hypolimnion. Most of the water column had dissolved-ammonia concentrations less than $5 \mu \mathrm{g} / \mathrm{L}$ throughout 1984 . August and September samples from the epilimnion had the lowest concentrations.

A statistical summary of dissolved ammonia concentrations, in micrograms per liter, is listed below for four depth strata at the west station.

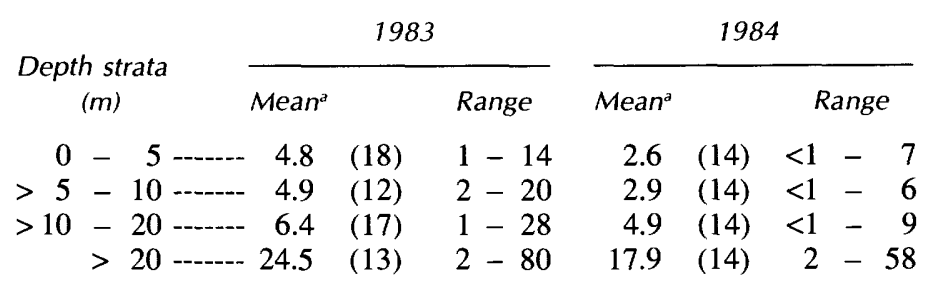

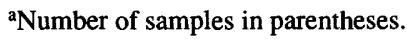



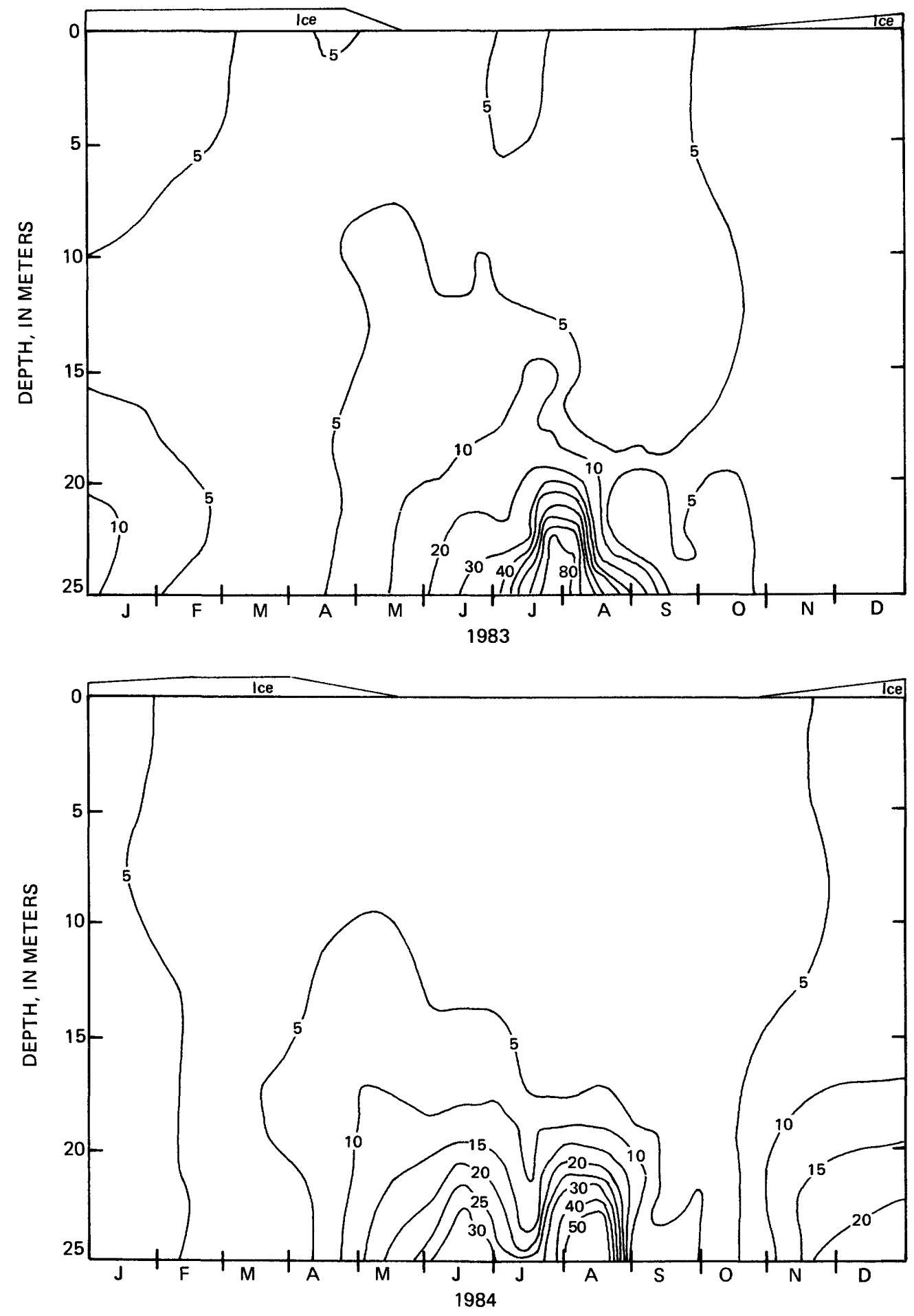

Figure 4.7.2.2. Lines of equal dissolved-ammonia concentrations (interval is 5 and $10 \mu \mathrm{g} / \mathrm{L}$ ) at the west station. 


\title{
4.0 CHEMICAL LIMNOLOGY-Continued
}

\author{
4.7 Nitrogen-Continued
}

4.7.3 Dissolved Nitrite Plus Nitrate

\subsubsection{East Station}

\section{Dissolved Nitrite Plus Nitrate Concentrations Were Reduced Substantially During Summer Stratification as a Result of Phytoplanktonic Assimilation}

\begin{abstract}
Nitrate assimilation and reduction by phytoplankton produced dissolved nitrite plus nitrate concentrations less than $1 \mu \mathrm{g} / \mathrm{L}$ within the epilimnion. Near the lake bottom, nitrification reactions yielded concentrations as high as $163 \mu \mathrm{g} / \mathrm{L}$.
\end{abstract}

During 1983, concentrations of dissolved nitrite plus nitrate were distinctly stratified over time and depth (fig. 4.7.3.1) and ranged from less than 1 to $163 \mu \mathrm{g} / \mathrm{L}$. In the epilimnion, concentrations as high as $80 \mu \mathrm{g} / \mathrm{L}$ were measured in February, whereas from May through October concentrations were typically less than $5 \mu \mathrm{g} / \mathrm{L}$. The buildup of dissolved nitrite plus nitrate under ice cover resulted when the rate of nitrate production by aerobic nitrification exceeded the uptake of nitrate by phytoplankton. As water temperatures and photosynthetically active radiation increased in the spring, the phytoplanktonic assimilation of nitrate increased rapidly and exceeded resupply processes; the result was a substantial decline in dissolved concentrations of nitrite and nitrate. In the hypolimnion, dissolved nitrite plus nitrate concentrations exceeded the range measured in the epilimnion. The lowest hypolimnetic concentrations occurred from June through October and resulted from denitrification, the bacterially mediated biochemical reduction of nitrite and nitrate. The largest hypolimnetic concentrations were measured under ice cover during January through mid-May. These latter concentrations resulted from nitrification reactions, which converted ammonia to nitrite and then nitrate. Although nitrification is an aerobic process, it can proceed at dissolved-oxygen concentrations as low as $0.3 \mathrm{mg} / \mathrm{L}$ (Wetzel, 1975); such concentrations were present at the east station of Big Lake. The source of the ammonia used in these nitrification reactions was the ammonification reactions near the lake bottom, which were discussed in section 4.7.2.1. Later in the year, hypolimnetic concentrations of dissolved nitrite plus nitrate increased again in response to nitrification of ammonia produced near the lake bottom during summer stratification.

The distribution of dissolved nitrite plus nitrate concentrations over time and depth during 1984 (fig. 4.7.3.1) was similar to that observed in 1983. Concentrations ranged from less than 1 to $162 \mu \mathrm{g} / \mathrm{L}$, nearly identical to those measured in 1983. The foregoing explanation of processes affecting dissolved nitrite plus nitrate concentrations during 1983 is applicable to 1984.

A statistical summary of dissolved nitrite plus nitrate concentrations, in micrograms per liter, measured during 1983 and 1984 is listed below for four depth strata at the east station.

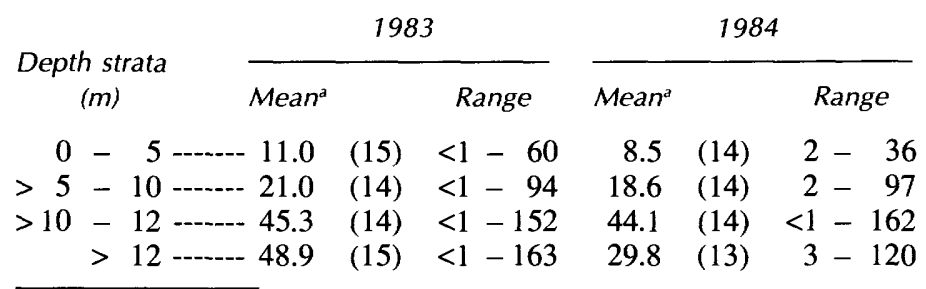

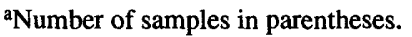



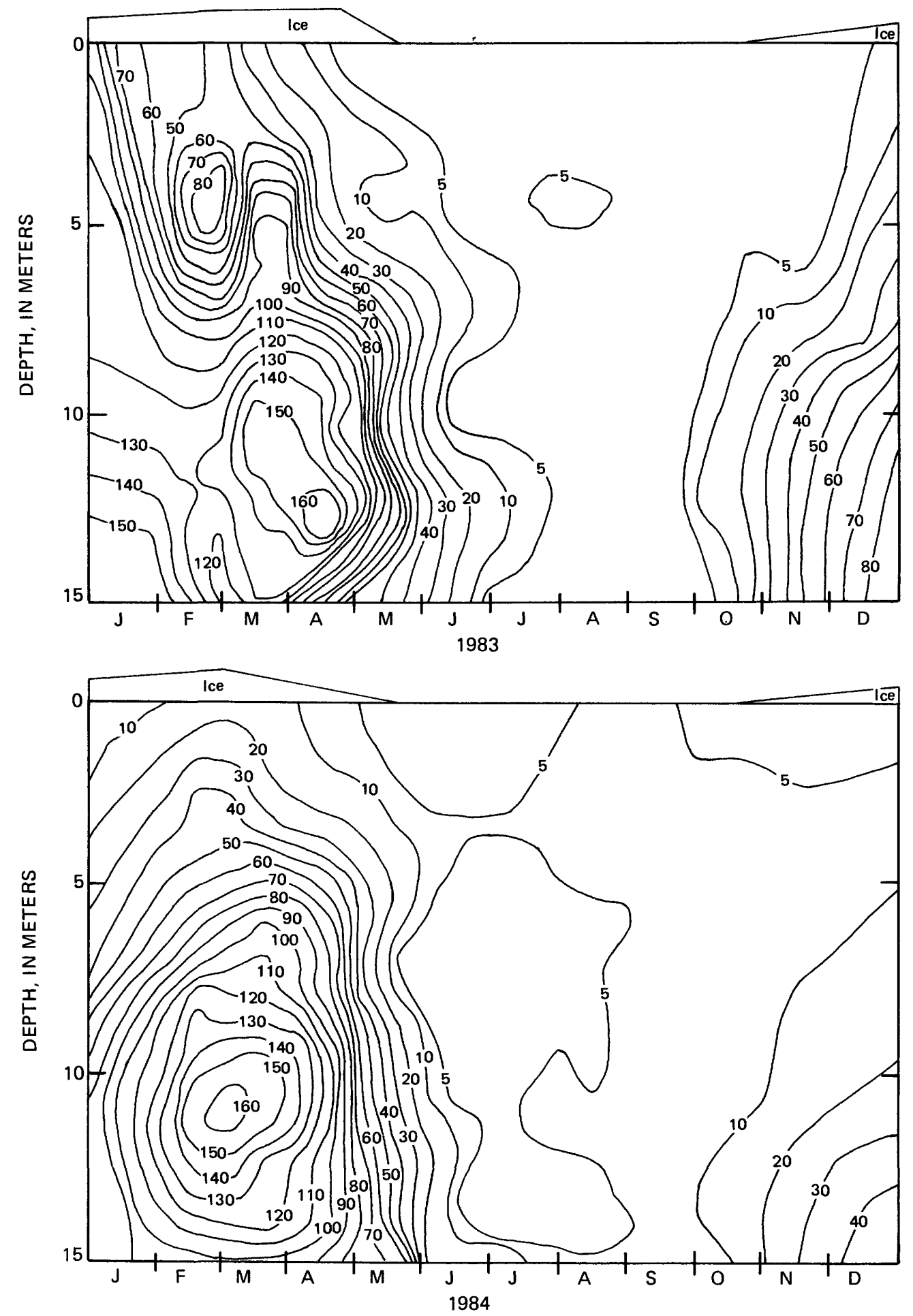

Figure 4.7.3.1. Lines of equal dissolved nitrite plus nitrate concentrations (interval is 5 and 10 $\mu \mathrm{g} / \mathrm{L})$ at the east station. 


\subsection{CHEMICAL LIMNOLOGY-Continued}

\subsection{Nitrogen-Continued}

4.7.3 Dissolved Nitrite Plus Nitrate-Continued

\subsubsection{West Station}

\section{Aerobic Conditions in Hypolimnion Promoted Rapid Nitrifi- cation of Ammonia Into Nitrite and Nitrate}

The near-absence of anoxic conditions in the hypolimnion allowed substantial nitrification of ammonia. As a result, the west station had peak concentrations of dissolved nitrite plus nitrate that exceeded those measured at the east station.

Concentrations of dissolved nitrite plus nitrate during 1983 ranged from less than 1 to $192 \mu \mathrm{g} / \mathrm{L}$ (fig. 4.7.3.2), with the largest concentrations measured near the lake bottom in February through April. The production of nitrate in the hypolimnion by nitrification was aided by the nearabsence of anoxic conditions near the lake bottom; thus, the peak concentrations at the west station exceeded those measured at the east station. The earlier discussion of dissolved ammonia at the west station in 1983 (fig. 4.7.2.2) indicated that ammonia concentrations did not increase substantially in the hypolimnion because of rapid nitrification of ammonia to nitrite and then nitrate. Beginning in May, dissolved concentrations of nitrite plus nitrate in the epilimnion were substantially reduced owing to assimilation by phytoplankton.
During 1984, dissolved concentrations of nitrite and nitrate ranged from 2 to $177 \mu \mathrm{g} / \mathrm{L}$ (fig. 4.7.3.2). The lowest concentrations were measured in the epilimnion during April through September and resulted from phytoplanktonic assimilation of nitrate. Within the hypolimnion there were two pulses of elevated concentrations, which resulted from nitrification of ammonia to nitrite and nitrate. The first pulse occurred near the bottom during February through April, whereas the second was measured during August and September.

Listed below is a statistical summary of dissolved nitrite plus nitrate concentrations, in micrograms per liter, measured during 1983 and 1984 at four depth strata at the west station.

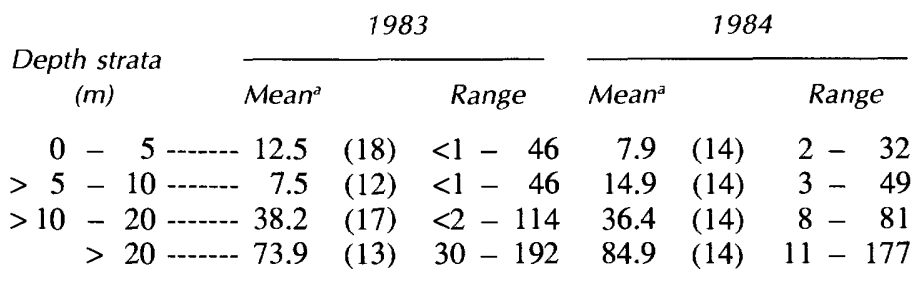

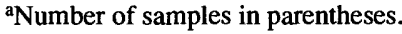



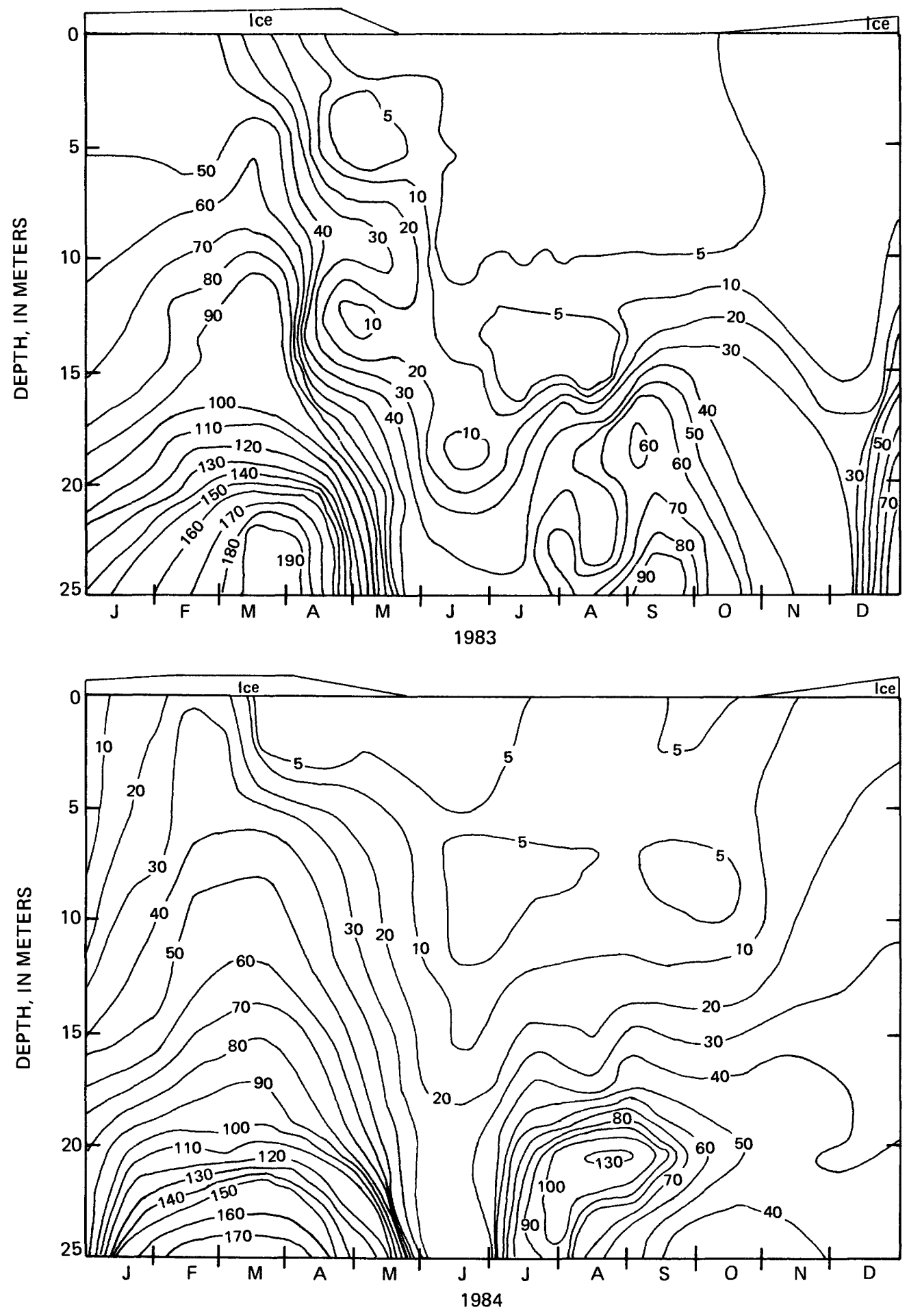

Figure 4.7.3.2. Lines of equal dissolved nitrite plus nitrate concentrations (interval is 5 and 10 $\mu \mathrm{g} / \mathrm{L})$ at the west station. 


\title{
4.0 CHEMICAL LIMNOLOGY-Continued
}

\author{
4.8 Nitrogen-to-Phosphorus Ratios
}

\section{Nitrogen Was the Nutrient Most Likely to Limit Phytoplank- ton Growth During Summer at Both Limnological Stations}

\begin{abstract}
Nitrogen-to-phosphorus ratios were typically less than 5 in the epilimnion at both stations during summer stratification; however, they frequently exceeded 10 during the winter months.
\end{abstract}

The limiting nutrient concept of Liebig (Welch, 1980) states that the ultimate yield of a crop will be limited by the essential nutrient that is most scarce relative to the specific needs of the crop. This concept, in concert with the stoichiometry of the photosynthesis equation $\left(106 \mathrm{CO}_{2}+90 \mathrm{H}_{2} \mathrm{O}+16 \mathrm{NO}_{3}+1 \mathrm{PO}_{4}+\right.$ light energy $\rightarrow$ $\mathrm{C}_{106} \mathrm{H}_{180} \mathrm{O}_{45} \mathrm{~N}_{16} \mathrm{P}_{1}+154.5 \mathrm{O}_{2}$ ), led to formulation of nitrogen-to-phosphorus ratios. These ratios are used extensively in eutrophication studies to determine whether nitrogen or phosphorus is the nutrient most likely to limit phytoplankton growth. The atom ratio $106 \mathrm{C}: 16 \mathrm{~N}: 1 \mathrm{P}$ in the photosynthesis equation corresponds to a mass ratio of $44 \mathrm{C}: 7 \mathrm{~N}: 1 \mathrm{P}$. Typically, nitrogen-to-phosphorus ratios are calculated using the biologically available forms of these two nutrients in the following equation:

$$
\mathrm{N}: \mathrm{P}=\mathrm{DIN} / \mathrm{P}
$$

where $\mathrm{N}: \mathrm{P}$ is the nitrogen-to-phosphorus ratio, unitless; DIN is the combined concentration, in micrograms per liter, of dissolved ammonia, nitrite, and nitrate; and OP is the concentration, in micrograms per liter, of dissolved orthophosphate.

In general, if $\mathrm{N}: \mathrm{P}$ (by weight) is less than 5 , nitrogen may be limiting, whereas if N:P exceeds 10 , then phosphorus may be the limiting nutrient. If $\mathrm{N}: \mathrm{P}$ falls between 5 and 10 , either nutrient may be limiting.

Variations in $\mathrm{N}: \mathrm{P}$ in the upper $10 \mathrm{~m}$ at both stations are depicted in figure 4.8. At the east station, a wide range in $\mathrm{N}: \mathrm{P}$ is apparent; however, the overall pattern is one of nitrogen limitation during summer stratification and a shift to phosphorus limitation during the winter. Of the $58 \mathrm{val}-$ ues at the east station, 33 were indicative of nitrogen limitation, 16 indicated phosphorus limitation, and 9 showed that either value could be limiting. The $\mathrm{N}: \mathrm{P}$ values from the 2-m depth strata were more likely to reveal nitrogen limitation than were those from the deeper strata. The seasonal pattern at the west station was similar, but the range in N:P was much less. Of the 58 values, 38 indicated nitrogen limitation, 6 indicated phosphorus limitation, and 14 showed that either nutrient could be limiting.

The prevalence of nitrogen limitation at both stations during summer stratification is attributable largely to phytoplanktonic consumption of dissolved inorganic nitrogen. Epilimnetic concentrations of dissolved ammonia and nitrite plus nitrate were taken to very low levels during the summer, whereas their concentrations in the winter were relatively high (figs. 4.7.2.1, 4.7.2.2, 4.7.3.1, 4.7.3.2). Conversely, dissolved-orthophosphate concentrations in the epilimnion were relatively uniform, ranging between 1 and $7 \mu \mathrm{g} / \mathrm{L}$ (figs. 4.6.2.1, 4.6.2.2). Therefore, shifts to phosphorus limitation during the winter were not actually due to decreased phosphorus but rather to large increases in dissolved inorganic nitrogen, which were generated by ammonification and nitrification reactions. 

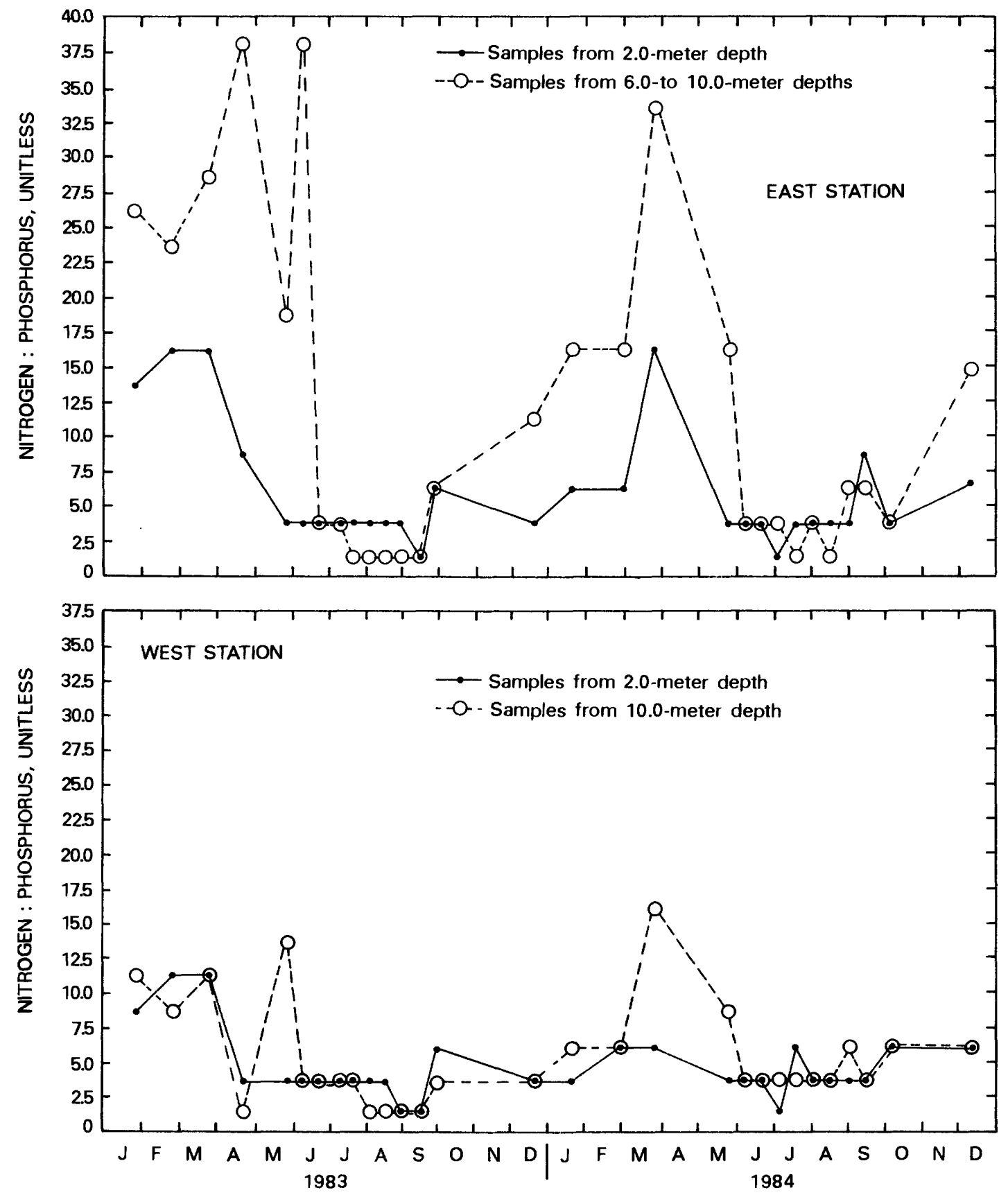

Figure 4.8. Nitrogen-to-phosphorus ratios. 


\title{
5.0 BIOLOGICAL LIMNOLOGY
}

5.1 Chlorophyll-a

\subsubsection{East Station}

\section{Largest Concentrations of Chlorophyll-a Occurred in the Hypolimnion During Summer}

\author{
Chlorophyll-a concentrations ranged from 0.05 to $46.5 \mu \mathrm{g} / \mathrm{L}$ during $1983-84$ at the east \\ station.
}

The distribution of chlorophyll- $a$ concentrations during 1983-84 was intensively studied at both limnological stations. Chlorophyll- $a$ is the primary photosynthetic pigment of phytoplankton and thus was an essential component of the primary-production experiments at Big Lake. Chlorophyll- $a$ is also a widely cited and accepted indicator of lake trophic state (Rast, 1981).

Concentrations of chlorophyll- $a$, in micrograms per liter, at the east station ranged from 0.05 to 46.5 (mean=3.9, $n=101$ ) in 1983 and from 0.05 to 9.2 (mean=2.6, $n=102$ ) in 1984 (fig. 5.1.1). There was no significant difference between the two mean concentrations. The lowest concentrations were measured between October and March under winter ice cover, when in situ photosynthetically active radiation was reduced. In midMarch, chlorophyll- $a$ concentrations began to increase in the upper $5 \mathrm{~m}$ of the lake even though the ice cover was at its maximum thickness. The increase in concentration was likely due to an increase in in situ photosynthetically active radiation because March received substantially more solar irradiance than did February (fig. 3.2).
Chlorophyll- $a$ concentrations did not exceed $5.5 \mu \mathrm{g} / \mathrm{L}$ in the upper $5 \mathrm{~m}$ of the east station throughout the study. The yearly maximum concentration of chlorophyll- $a$ occurred near the lower depth limit of the euphotic zone. In 1983 , the maximum concentration of $46.5 \mu \mathrm{g} / \mathrm{L} \mathrm{oc}-$ curred at a depth of $9 \mathrm{~m}$ between late July and early September. The maximum concentration for 1984 was measured in early June at $9.4 \mathrm{~m}$. Big Lake's deep-lying chlorophyll maxima were situated in the hypolimnion, in that the depth of the euphotic zone normally exceeded the depth of the epilimnion during late May through mid-September.

The occurrence of high concentrations of chlorophyll in a hypolimnion that also contains part of the euphotic zone may indicate that photosynthetic bacteria have contributed to the chlorophyll pool; however, anoxic conditions also must exist because such bacteria are obligate anaerobes (Rheinheimer, 1974). The deep-lying chlorophyll maxima in Big Lake developed in well-oxygenated water (fig. 4.3.1); thus, photosynthetic bacteria did not explain the high concentrations of chlorophyll-a. 

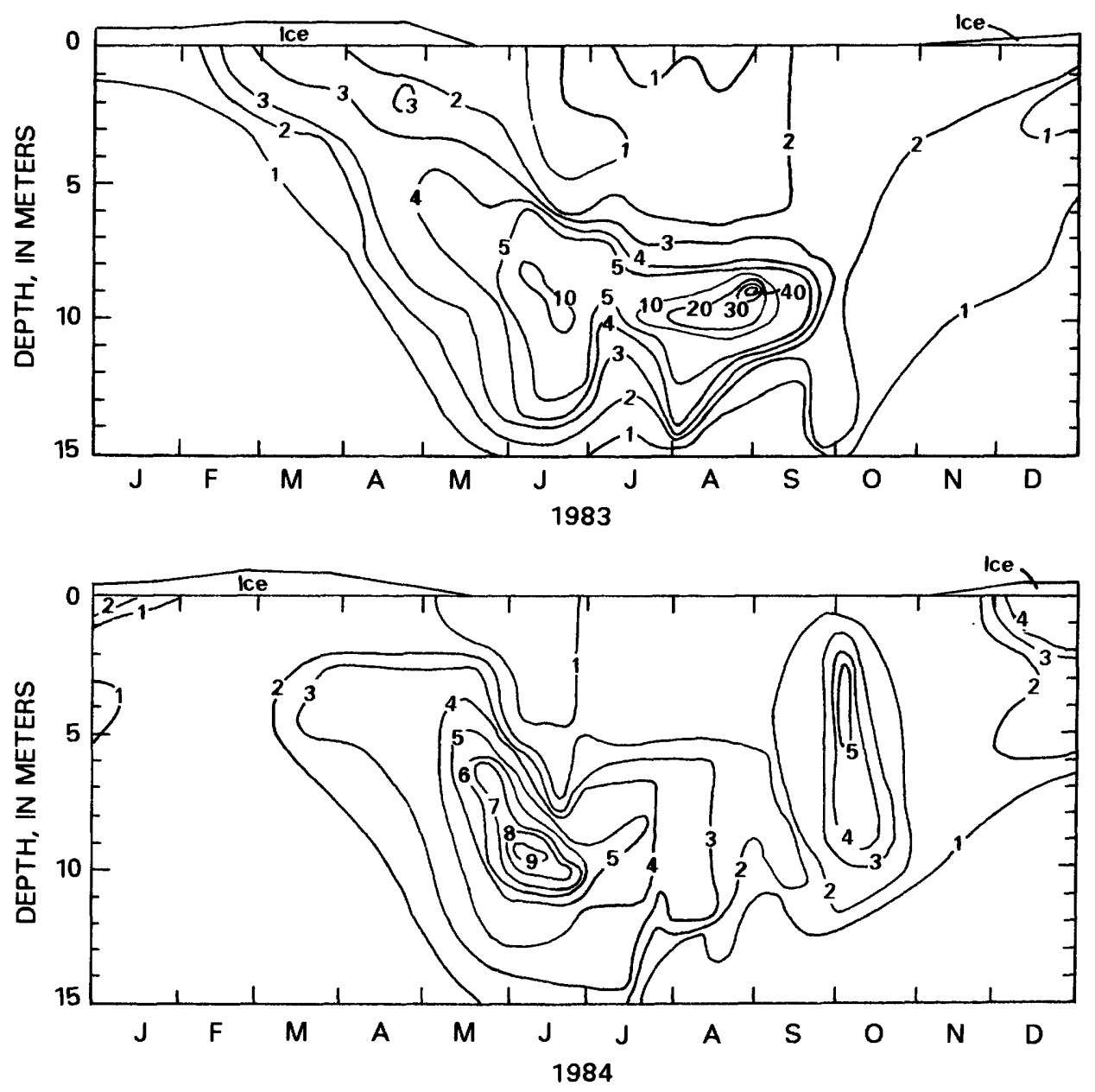

Figure 5.1.1. Lines of equal chlorophyll-a concentrations (interval, in micrograms per liter, is variable) at the east station. 


\subsection{BIOLOGICAL LIMNOLOGY-Continued}

5.1 Chlorophyll-a-Continued

\subsubsection{West Station}

\section{Chlorophyll-a Concentrations at West Station Were Signifi- cantly Lower Than Those at East Station}

Chlorophyll-a concentrations at the west station ranged from 0.07 to $8.0 \mu \mathrm{g} / \mathrm{L}$ during 1983-84.

Chlorophyll- $a$ concentrations, in micrograms per liter, at the west station ranged from 0.07 to 8.0 (mean=1.8, $n=108$ ) in 1983 and from 0.14 to 6.4 (mean $=1.7, n=107$ ) in 1984 (fig. 5.1.2). There was no significant difference between the two mean concentrations. Parametric statistical tests (Student's $t$ ) indicated that chlorophyll- $a$ concentrations at the east station were significantly higher than those at the west station. The seasonal pattern for chlorophyll- $a$ at the west station was similar to that at the east station, although the west station did not experience concentrations greater than 8 $\mu \mathrm{g} / \mathrm{L}$. Chlorophyll- $a$ concentrations in the upper $5 \mathrm{~m}$ at the west station did not exceed $3.5 \mu \mathrm{g} / \mathrm{L}$ during $1983-$ 84 . The yearly maximum concentrations occurred in the hypolimnion within a month of the melting of the lake's ice cover.

Deep-lying chlorophyll maxima such as those observed at the east and west stations of Big Lake have been reported to occur under similar conditions in many lakes (Fee, 1976; Priscu and Goldman, 1983; Pick and others, 1984). The chlorophyll maxima in these other lakes have frequently been composed of flagellated, colonial algae of the subphylum Chrysophyceae (Fee, 1976; Pick and others, 1984). 

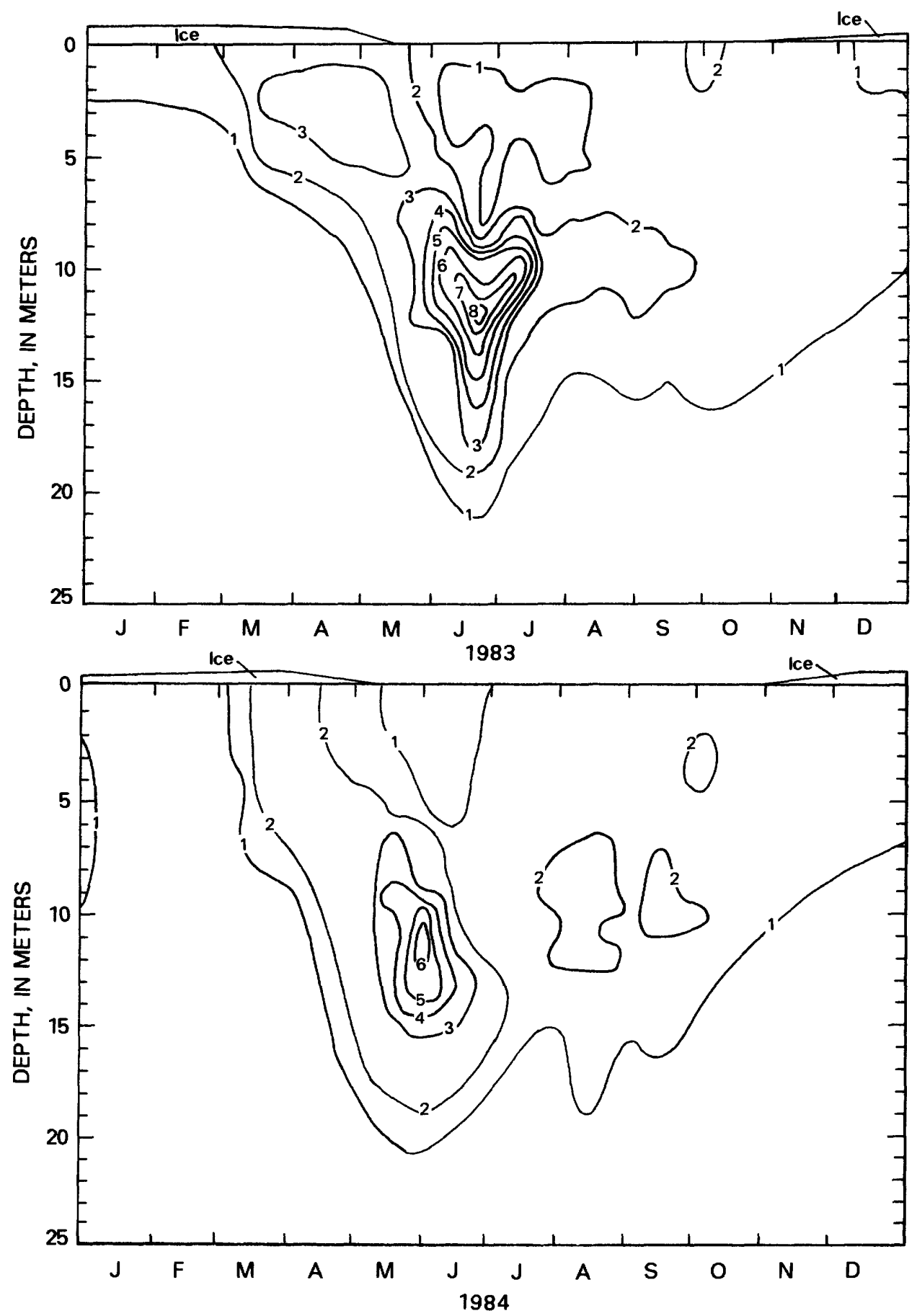

Figure 5.1.2. Lines of equal chlorophyll-a concentrations (interval is $1 \mu \mathrm{g} / \mathrm{L}$ ) at the west station. 


\subsection{BIOLOGICAL LIMNOLOGY-Continued}

\subsection{Phytoplankton}

5.2.1 Taxonomic Listing

\section{Phytoplankton Samples From Two Limnological Stations Contained 36 Genera, Representing Five Algal Phyla}

The following algal phyla were represented by the phytoplankton samples collected at Big Lake during 1983-84: Chlorophyta, Chrysophyta, Cryptophyta, Cyanophyta, and Pyrrhophyta.

The taxonomic composition of phytoplankton in Big Lake during 1983-84 was determined from samples collected at depths between 2 and $10 \mathrm{~m}$. Analyses of these samples resulted in identification of the 36 algal genera listed in table 5.2.1. Numerous unidentified microalgae were also present in the samples. The following five phyla were represented: Chlorophyta, or green algae; Chrysophyta, the yellow-green algae; Cryptophyta, the cryptomonads; Cyanophyta, the blue-green algae; and Pyrrhophyta, the dinoflagellates. 
Table 5.2.1. Taxonomic composition' of Big Lake phytoplankton during 1983-84

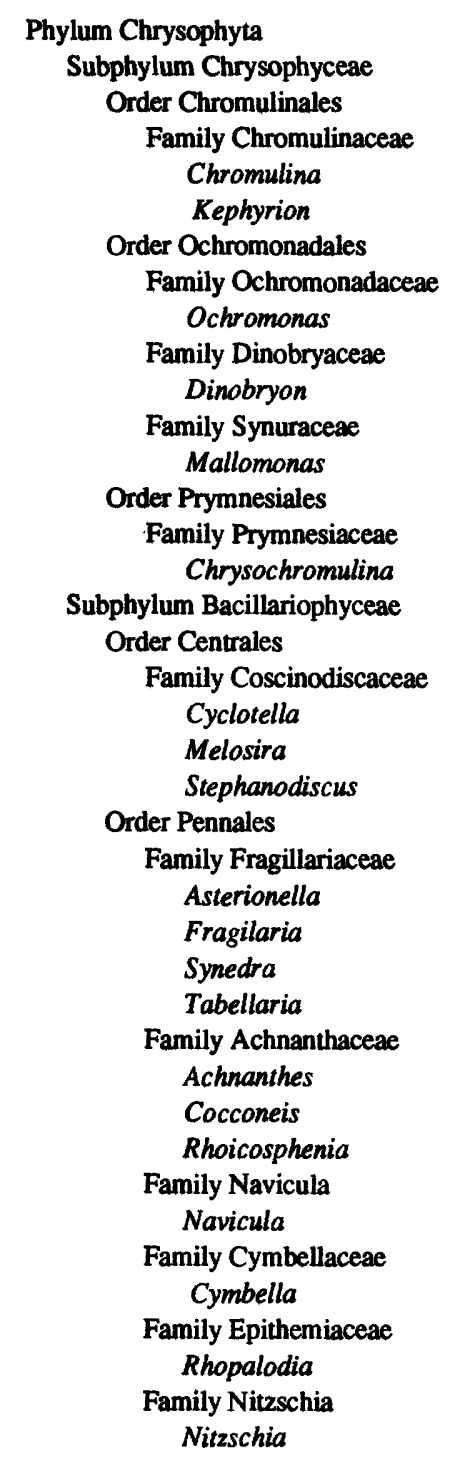

\section{Phylum Chlorophyta \\ Subphylum Chlorophyceae \\ Order Volvocales}

Family Chlamydomonadaceae Chlamydomonas

Order Chlorococcales

Family Oocystaceae Ankistrodesmus Quadrigula

Family Dictyosphaeriaceae Dictyosphaerium

Family Scenedesmaceae Crucigenia Scenedesmus

Order Zygnematales

Family Desmidiaceae Cosmarium

Phylum Cyanophyta

Order Chroococcales

Family Chroocaccaceae Chroococcus Merismopedium

Order Oscillatoriales Family Oscillatoriaceae Oscillatoria

Order Nostocales

Family Nostocaceae Anabaena

Phylum Pyrrhophyta

Class Dinophyceae

Order Dinokontae

Family Gymnodiniaceae Gymnodinium

Family Peridiniaceae Peridinium

Phylum Cryptophyta

Family Cryptochrysidaceae Chroomonas Rhodomonas

Family Cryptomonadaceae Crytomonas

Taxonomy based on Prescott (1970). 


\title{
5.0 BIOLOGICAL LIMNOLOGY_Continued
}

\subsection{Phytoplankton-Continued}

\subsubsection{Percentage Composition}

\section{Percentage Composition of Big Lake's Phytoplankton Was Numerically Dominated by Microalgae}

\begin{abstract}
Although unidentified microalgae numerically dominated the percentage composition of phytoplankton, the largest contribution to phytoplankton biomass (expressed as carbon content per liter) was from the phylum Chrysophyta.
\end{abstract}

The percentage composition of the phytoplankton as shown in table 5.2.2 is expressed as number of cells per liter and as carbon content per liter. The carbon content was determined as the sum of the products of each taxonomic group's density times its literature-referenced value for cellular carbon content. The summary statistics are for all samples taken over the 2-yr period at both limnological stations, except that the means and ranges are subdivided into shallow samples (depths from 1 to $2 \mathrm{~m}$ ) and deep samples (depths from 5 to $10 \mathrm{~m}$ ).

On the basis of the number of cells per liter, the microalgae clearly dominated the phytoplankton composition. The subphylum Chrysophyceae was a distant second at both depth classes. The Cyanophyta made the smallest contribution. Note, however, that wide ranges were recorded for all the taxonomic designations.

When based on carbon content, the percentage composition is significantly altered. The subphylum Chrysophyceae becomes dominant at both depth classes, whereas the microalgae rank third in their contribution to biomass. Again, the Cyanophyta contributed the least amount of biomass at both depth classes. 
Table 5.2.2. Percentage composition by number of cells per liter and carbon content per liter of phytoplankton collected from the east and west limnological stations during 1983-84

Percentage composition by number of cells per liter

\begin{tabular}{|c|c|c|c|c|}
\hline \multirow{2}{*}{ Taxonomic designation } & \multicolumn{2}{|c|}{ Shallow samples ${ }^{1}$} & \multicolumn{2}{|c|}{ Deep samples $^{2}$} \\
\hline & Mean $^{3}$ & Range & Mean ${ }^{4}$ & Range \\
\hline \multicolumn{5}{|l|}{ Phylum Chrysophyta } \\
\hline Subphylum Bacillariophyceae & 3.5 & $0-16.4$ & 5.9 & $0-23.0$ \\
\hline Subphylum Chrysophyceae & 15.0 & $0-36.7$ & 14.8 & $0-40.0$ \\
\hline Phylum Cyanophyta & 1.9 & $0-20.6$ & 3.7 & $0-20.8$ \\
\hline \multicolumn{5}{|l|}{ Other phyla (Chlorophyta, } \\
\hline Pyrrhophyta, Cryptophyta) & 6.0 & $0-26.2$ & 6.7 & $0-19.8$ \\
\hline \multirow[t]{3}{*}{ Unidentified microalgae } & 73.8 & $30.0-100.0$ & 69.2 & $39.1-99.9$ \\
\hline & \multicolumn{4}{|c|}{ Percentage composition by carbon content per liter } \\
\hline & \multicolumn{2}{|c|}{ Shallow samples ${ }^{1}$} & \multicolumn{2}{|c|}{ Deep samples ${ }^{2}$} \\
\hline Taxonomic designation & $\overline{\operatorname{Mean}^{3}}$ & Range & Mean $^{4}$ & Range \\
\hline \multicolumn{5}{|l|}{ Phylum Chrysophyta } \\
\hline Subphylum Bacillariophyceae & 10.5 & $0-46.1$ & 11.8 & $0-40.7$ \\
\hline Subphylum Chrysophyceae & 37.3 & $0-80.4$ & 36.7 & $0-82.5$ \\
\hline Phylum Cyanophyta & 7.5 & $0 \cdot 66.1$ & 7.8 & $0-34.0$ \\
\hline \multicolumn{5}{|l|}{ Other phyla (Chlorophyta, } \\
\hline Pyrrhophyta, Cryptophyta) & 24.1 & $0-70.3$ & 24.8 & $0-52.0$ \\
\hline Unidentified microalgae & 20.6 & $5.2-100.0$ & 18.9 & $3.9-99.6$ \\
\hline
\end{tabular}

${ }^{1}$ Samples from between 1 and $2 \mathrm{~m}$.

${ }^{2}$ Samples from between 5 and $10 \mathrm{~m}$.

${ }^{3}$ Number of samples is 58 .

Number of samples is 48 . 


\subsection{BIOLOGICAL LIMNOLOGY - Continued}

\subsection{Phytoplankton-Continued}

\subsubsection{Spatial and Temporal Trends in Phytoplankton Abundance}

\section{Phytoplankton Abundance Ranged From $1.20 \times 10^{6}$ to 107.0×10 ${ }^{6}$ Cells Per Liter During 1983-84}

The abundance of phytoplankton in samples collected from depths between 5 and 10 meters was generally larger than for samples collected within the upper 2 meters of the water column.

Spatial and temporal trends in phytoplankton abundance during 1983-84 at both limnological stations are illustrated in figure 5.2.3. In general, the deep samples (depths from 5 to $10 \mathrm{~m}$ ) contained more phytoplankton cells per liter than did the shallow samples (depths from 1 to $2 \mathrm{~m}$ ), except in 1984 at the west station. The highest number of cells per liter, $107.0 \times 10^{6}$, was measured for the deep sample from the west station in late August 1983. The least number of cells per liter, $1.20 \times 10^{6}$, occurred in the shallow sample from the east station in late February 1984. This overall range in phytoplankton abundance for Big Lake places the lake within the typical range of $10^{5}$ to $10^{8}$ phytoplankton cells per liter cited by Cole (1982).

At the east station during 1983, the mean number of cells per liter was $5.44 \times 10^{6}$ (range from $2.3 \times 10^{6}$ to $8.7 \times 10^{6}$ ) for shallow samples and $9.36 \times 10^{6}$ (range from $4.1 \times 10^{6}$ to $21.0 \times 10^{6}$ ) for deep samples. The largest values were attained in mid-June for both shallow and deep samples. In 1984, the mean numbers of cells per liter for shallow and deep samples at the east station were slightly higher than in 1983. The shallow and deep samples respectively contained an average of $6.70 \times 10^{6}$ (range from $1.2 \times 10^{6}$ to $11.0 \times 10^{6}$ ) and $11.9 \times 10^{6}$ (range from $4.4 \times 10^{6}$ to $27.0 \times 10^{6}$ ) cells per liter during 1984 . The peak in abundance occurred in the deep sample for early June, whereas shallow-sample abundance peaked in late March.

The mean number of cells per liter at the west station during 1983 was $6.43 \times 10^{6}$ (range from $2.7 \times 10^{6}$ to $12.0 \times 10^{6}$ ) for shallow samples and $14.4 \times 10^{6}$ (range from $2.8 \times 10^{6}$ to $107.0 \times 10^{6}$ ) for deep samples. Peak abundances were measured in late August. The shallow and deep samples respectively contained an average of $6.36 \times 10^{6}$ (range from $2.6 \times 10^{6}$ to $16.0 \times 10^{6}$ ) and $7.44 \times 10^{6}$ (range from $3.2 \times 10^{6}$ to $12.0 \times 10^{6}$ ) cells per liter in 1984. Shallow-sample abundance peaked in early June, whereas the peak in the deep samples occurred in mid-September. 

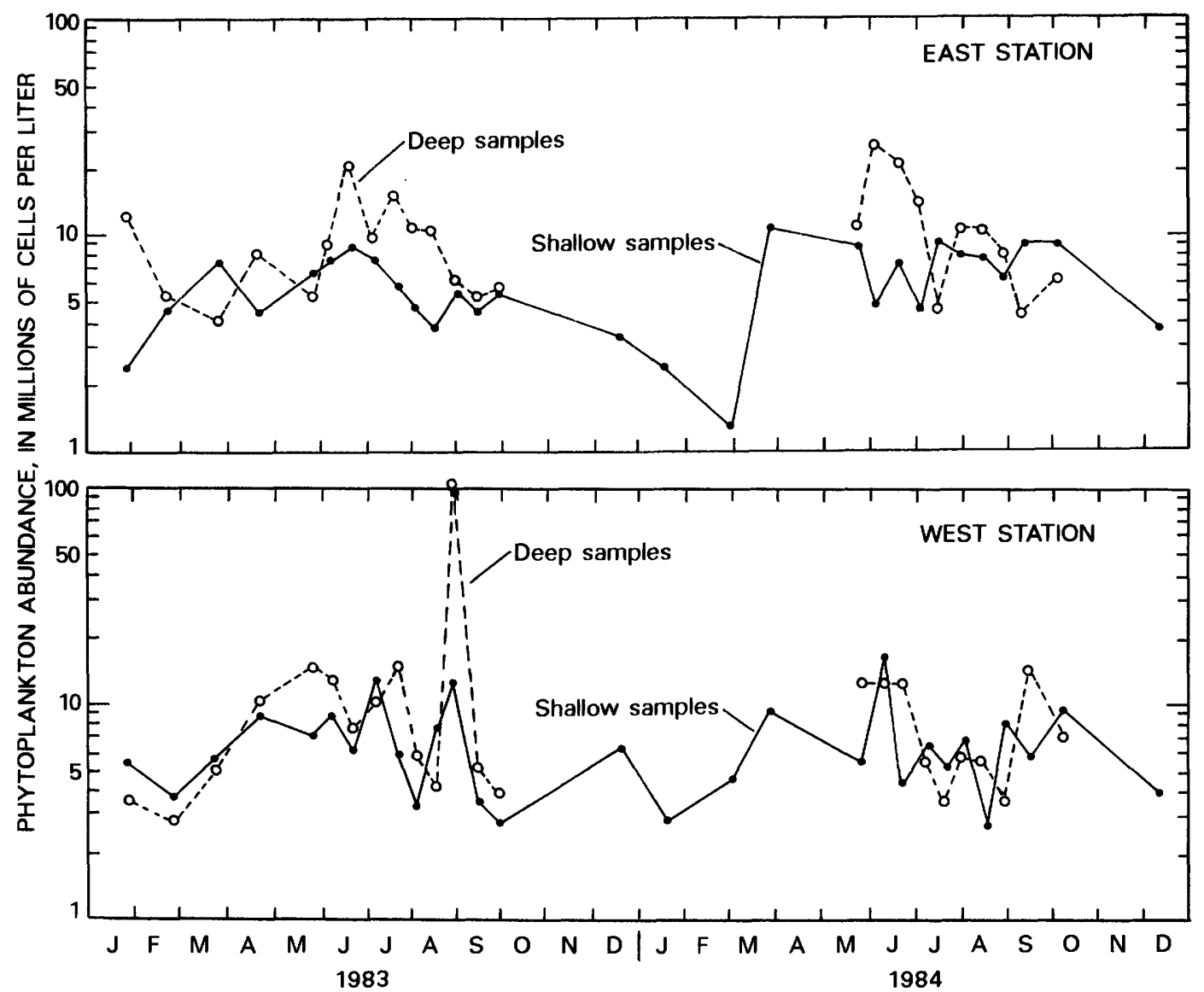

Figure 5.2.3. Phytoplankton abundance. 


\title{
6.0 PRIMARY PRODUCTION OF PHYTOPLANKTON
}

\author{
6.1 Annual Rate
}

\section{Annual Integral Primary Production of Phytoplankton in Big Lake During 1984 Was 29.6 Grams of Carbon Per Square Meter}

When compared with the range in annual primary production of 50 lakes studied under the International Biological Program, the annual primary production of Big Lake is low.

The primary production of numerous lakes throughout the world has been studied under the auspices of the International Biological Program (IBP). The annual net primary production, in grams of carbon per square meter $\left(\mathrm{g} \mathrm{C} / \mathrm{m}^{2}\right)$ of 50 IBP lakes varied from 3.6 at Lake Krugloye $\left(65^{\circ}\right.$ N., $35^{\circ}$ E.) in the U.S.S.R. to 2,200 at Red Rock Tarn ( $38^{\circ}$ S., $143^{\circ}$ E.), a shallow, saline lake in Australia (LeCren and Lowe-McConnell, 1980). Other investigators have reported annual rates of primary production that lie outside the range of the IBP lakes. Aleem and Samaan (1969) found that an Egyptian lake, Mariut, annually produced $2,667 \mathrm{~g} \mathrm{C} / \mathrm{m}^{2}$; some Alaskan ponds studied by Kalff (1967a) annually produced between 0.38 to 0.85 $\mathrm{g} \mathrm{C} / \mathrm{m}^{2}$.

In Alaska, numerous measurements of daily integral primary production have been made (Goldman, 1960; Hobbie, 1964; Kalff, 1967a, b; Barsdate and Alexander, 1971; Howard and Prescott, 1971; LaPerriere and others, 1978; Koenings and Kyle, 1982; Woods and Rowe, 1986); however, few studies of annual primary production have been done on Alaskan lakes. Hobbie (1964) measured an annual primary production of only $0.9 \mathrm{~g} \mathrm{C} / \mathrm{m}^{2}$ in turbid Lake Peters $\left(69^{\circ} 22^{\prime}\right.$ N., $145^{\circ} \mathrm{W}$.) in the Brooks Range, whereas adjacent Lake Schrader produced between 6.6 and $7.5 \mathrm{~g} \mathrm{C} / \mathrm{m}^{2}$. The annual primary production of Imikpuk Lake at Barrow $\left(71^{\circ} 18^{\prime} \mathrm{N} ., 156^{\circ} 40^{\prime} \mathrm{W}\right.$.) was $8.4 \mathrm{~g} \mathrm{C} / \mathrm{m}^{2}$ (Kalff, 1967b). The Tangle Lakes system $\left(63^{\circ}\right.$ N., $146^{\circ}$ W.) in interior, subarctic Alaska was estimated to annually produce about $30 \mathrm{~g} \mathrm{C} / \mathrm{m}^{2}$ (Barsdate and Alexander, 1971). LaPerriere and others (1978) studied Harding Lake $\left(64^{\circ} 25^{\prime}\right.$ N., $146^{\circ} 50^{\prime}$ W.) near Fairbanks and reported its annual pri- mary production to be $47.8 \mathrm{~g} \mathrm{C} / \mathrm{m}^{2}$.

The annual integral primary production of Big Lake during 1984 was $29.6 \mathrm{~g} \mathrm{C} / \mathrm{m}^{2}$ (fig. 6.1), which yields a mean daily rate of 81.1 milligrams of carbon per square meter $\left(\mathrm{mg} \mathrm{C} / \mathrm{m}^{2}\right)$. The east basin had a slightly higher areal rate, but it had a smaller surface area; thus, the west basin contributed more carbon during the year.

The annual primary production of Big Lake ranks low when compared with the 50 IBP lakes reported on by LeCren and Lowe-McConnell (1980). The range in annual primary production given above for six Alaskan lakes, 0.9 to $47.8 \mathrm{~g} \mathrm{C} / \mathrm{m}^{2}$, would place Big Lake near the median; however, several of these lakes are not suitable for comparison with Big Lake. Three of the lakes-Peters, Schrader, and Imikpuk - are located north of the Arctic Circle and are exposed to climatic conditions quite different from those at Big Lake. The Tangle Lakes system is subarctic, but the estimate of annual primary production was based on just a few in situ C-14 incubations that were done only during the months of July, August, and September of 1966-67. Numerous in situ C-14 incubations were done during 1975 at Harding Lake as part of a waterquality study of the lake (LaPerriere and others, 1978). The scope and methods of the Harding Lake study make it the most realistic comparison to Big Lake. Harding Lake has a surface area of $988 \mathrm{hm}^{2}$ and a mean depth of $16 \mathrm{~m}$. As at Big Lake, the shoreline is extensively developed and the principal method of waste disposal is by privy. The annual primary production of Harding Lake in 1975 was $47.8 \mathrm{~g} \mathrm{C} / \mathrm{m}^{2}$, about 161 percent of that measured in Big Lake during 1984. 
65,140 square meters at 29.185 grams of carbon per square meter per year equals $1,901,111$ grams of carbon per year.

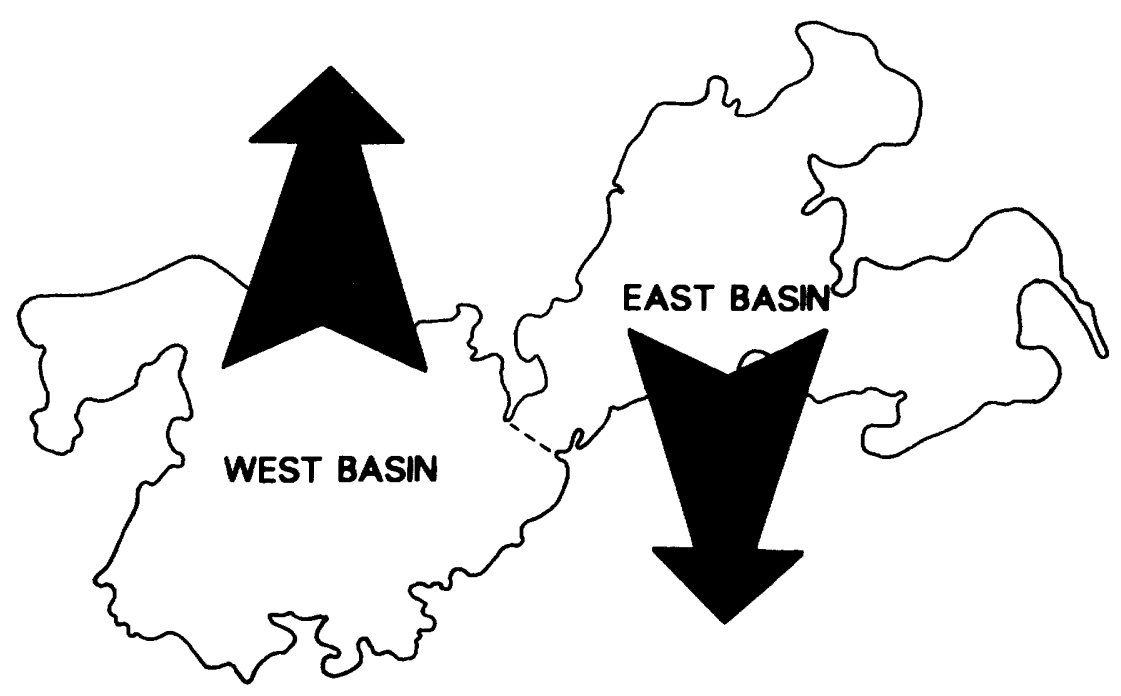

ANNUAL PRIMARY PRODUCTION - EAST BASIN

56,160 square meters at 30.08 grams of carbon per square meter per year equals $1,689,124$ grams of carbon per year.

ANNUAL PRIMARY PRODUCTION - ENTIRE LAKE

$(1,901,111+1,689,124)$

$(65,140+56,160)=29.6$ grams of carbon per square meter

\section{MEAN DAILY PRIMARY PRODUCTION - ENTIRE LAKE}

29.6

$\times 1,000=81.1$ milligrams of carbon per square meter

365

Figure 6.1. Distribution of annual primary production for the east and west basins. 


\subsection{PRIMARY PRODUCTION OF PHYTOPLANKTON-Continued}

6.2 Monthly Rates

\section{July Had the Highest Monthly Rate of Integral Primary Pro- duction and January Had the Lowest}

Less than 10 percent of the lake's annual integral primary production was measured during November through April, when the lake was ice covered.

The monthly integral primary production at Big Lake's two primary limnological stations and each month's percentage contribution to the annual integral primary production at each station are listed in table 6.2. Monthly integral primary production ranged from 1.7 to $6,580 \mathrm{mg} \mathrm{C} / \mathrm{m}^{2}$ at the east station and from 1.5 to about $7,050 \mathrm{mg} \mathrm{C} / \mathrm{m}^{2}$ at the west station. At both stations the maximum monthly rate was measured in July; January had the lowest rate. Compared with the east station, the west station had higher monthly rates of primary production during March through July. The 6-month period from May through October (open-water season) contributed 93.9 and 89.8 percent of the annual integral primary production of the east and west stations, respectively. At the east station, the 3-month period of July through September contributed 60.6 percent of annual integral primary production; the same period at the west station contributed 56.2 percent. The large percentage contribution to annual integral primary production from the summer months was largely attributable to increased solar irradiance (fig. 3.2), deeper euphotic-zone depths (fig. 3.4), warmer water temperatures (figs. 3.5.1, 3.5.2), and higher concentrations of chlorophyll- $a$ (figs. 5.1.1, 5.1.2).

The primary-production data for Harding Lake, Alaska, were available for comparison with the monthly rates of integral primary production at Big Lake. Figure 19 in the report by LaPerriere and others (1978) was digitally planimetered to derive monthly rates of integral primary production at Harding Lake for 1975. Of the $47.8 \mathrm{~g} \mathrm{C} / \mathrm{m}^{2}$ produced annually in Harding Lake, 94.8 percent was produced from May through October; June had the largest percentage contribution, 23.2. Monthly integral primary production in Harding Lake ranged from 90 to $11,070 \mathrm{mg}$ $\mathrm{C} / \mathrm{m}^{2}$ and thus exceeded the range measured in Big Lake, 1.5 to about $7,050 \mathrm{mg} \mathrm{C} / \mathrm{m}^{2}$ per month. The results of primary-production studies at Big and Harding Lakes suggest that future primary-production measurements might be made only during the open-water season because less than 10 percent of the annual integral primary production of these two lakes occurred under ice cover. 
Table 6.2. Monthly integral primary production and each month's percentage contribution to annual integral primary production for the east and west limnological stations during 1984

\begin{tabular}{|c|c|c|c|c|}
\hline \multirow[t]{2}{*}{ Month } & \multicolumn{2}{|c|}{$\begin{array}{l}\text { Monthly integral primary } \\
\text { production (milligrams of } \\
\text { carbon per square meter) }\end{array}$} & \multicolumn{2}{|c|}{$\begin{array}{l}\text { Percentage of annual } \\
\text { integral primary } \\
\text { production }\end{array}$} \\
\hline & East & West & East & West \\
\hline January & 1.7 & 1.5 & $<0.1$ & $<0.1$ \\
\hline February & 86.5 & 49.7 & 0.3 & 0.2 \\
\hline March & 339.1 & 772.5 & 1.1 & 2.6 \\
\hline April & $1,105.5$ & $2,112.3$ & 3.7 & 7.2 \\
\hline May & $3,616.0$ & $3,798.9$ & 12.0 & 13.0 \\
\hline June & $3,703.4$ & $4,049.6$ & 12.3 & 13.9 \\
\hline July & $6,580.0$ & $7,052.4$ & 21.9 & 24.2 \\
\hline August & $6,121.8$ & $5,343.8$ & 20.4 & 18.3 \\
\hline September & $5,502.4$ & $3,987.3$ & 18.3 & 13.7 \\
\hline October & $2,721.9$ & $1,944.3$ & 9.0 & 6.7 \\
\hline November & 225.4 & 56.7 & 0.7 & 0.2 \\
\hline December & 73.0 & 16.1 & 0.2 & $<0.1$ \\
\hline Annual & $30,076.7$ & $29,185.1$ & 100.0 & 100.0 \\
\hline
\end{tabular}


6.3 Daily Rates

6.3.1 East Station

\section{Daily Rates of Integral Primary Production at East Station Ranged From Less Than 0.1 to 283.6 Milligrams of Carbon Per Square Meter}

On the basis of the mean rate of daily integral primary production, January was the least productive month, whereas July was the most productive one.

A wide range in daily integral primary production was measured during 1984 at the east station of Big Lake (fig. 6.3.1). Integral daily rates, in milligrams of carbon per square meter, were less than 0.1 in early January; they peaked at 283.6 on July 15 . The mean daily integral rate for each month ranged from less than $0.1 \mathrm{mg} \mathrm{C} / \mathrm{m}^{2}$ in January to $212.3 \mathrm{mg} \mathrm{C} / \mathrm{m}^{2}$ in July. During the period of ice cover daily integral primary production did not exceed 60 $\mathrm{mg} \mathrm{C} / \mathrm{m}^{2}$ because of cold water temperatures, a shallow euphotic zone, and limited amounts of in situ PAR. When the lake's ice cover melted in mid-May, integral primary production rapidly increased in response to warmer water temperatures, substantial deepening of the euphotic zone, and large increases in the amount of in situ PAR. During mid-May through October, large day-to-day differences in integral primary production were largely attributable to daily variations in solar irradiance. The primaryproduction model, BIOMOD, is sensitive to changes in solar irradiance. For example, the daily integral primary production on August 25 was $137.2 \mathrm{mg} \mathrm{C} / \mathrm{m}^{2}$, whereas it was $230.5 \mathrm{mg} \mathrm{C} / \mathrm{m}^{2}$ on August 26. The most significant difference between these two dates was that the PAR, in Einsteins per square meter, received on August 25 was 15.9, but it was 34.5 on August 26. 


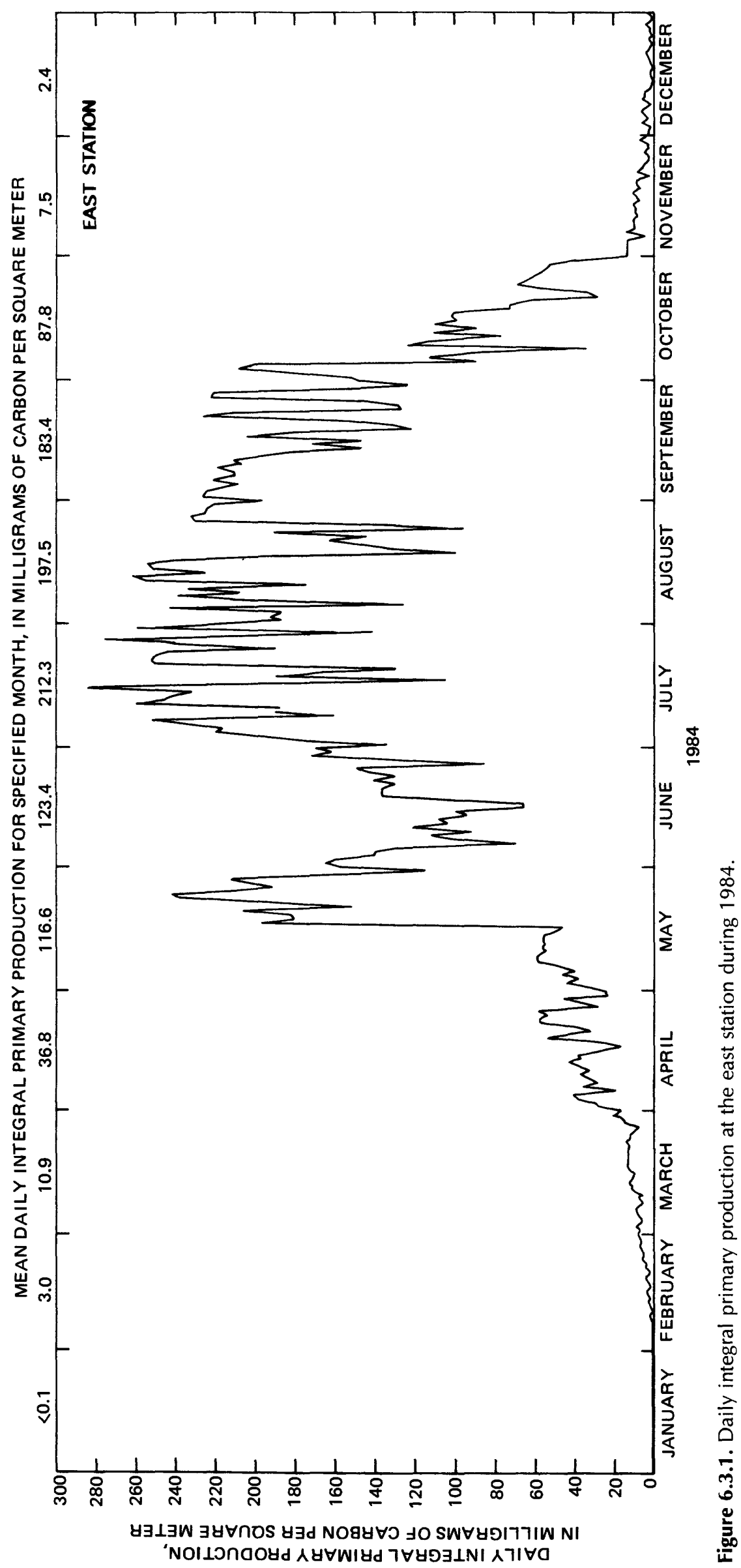




\title{
6.0 PRIMARY PRODUCTION OF PHYTOPLANKTON-Continued
}

\author{
6.3 Daily Rates-Continued
}

\subsubsection{West Station}

\section{Daily Integral Primary Production at West Station Ranged From Less Than 0.1 to 298.4 Milligrams of Carbon Per Square Meter}

The range in daily integral primary production at Big Lake during 1983 was within the range reported for five other subarctic Alaskan lakes.

The seasonal variation of daily integral primary production at the west station (fig. 6.3.2) was similar to that at the east station (fig. 6.3.1). January had the lowest mean daily rate at less than $0.1 \mathrm{mg} \mathrm{C} / \mathrm{m}^{2}$, whereas July, at 227.5 $\mathrm{mg} \mathrm{C} / \mathrm{m}^{2}$, had the highest mean daily rate. The maximum daily rate at $298.4 \mathrm{mg} \mathrm{C} / \mathrm{m}^{2}$ occurred on July 27 in conjunction with a solar-irradiance input of $39.2 \mathrm{E} / \mathrm{m}^{2}$.

The daily rates of integral primary production measured at Big Lake during 1984 (0 to $298.4 \mathrm{mg} \mathrm{C} / \mathrm{m}^{2}$ ) can be compared with those of the 50 IBP lakes reported on by LeCren and Lowe-McConnell (1980). These authors reported that one of the least productive IBP lakes was Char Lake $\left(74^{\circ} \mathrm{N} ., 94^{\circ} \mathrm{W}\right.$.) in Canada with a range of daily integral primary production from 0 to $70 \mathrm{mg} \mathrm{C} / \mathrm{m}^{2}$ $\left(0-210 \mathrm{mg} \mathrm{O} / \mathrm{m}^{2}\right)$. The most productive IBP lake was Red Rock Tarn, which had daily integral primary preduction from 60 to $17,667 \mathrm{mg} \mathrm{C} / \mathrm{m}^{2}$ (180-53,000 mg $\mathrm{O}_{2} / \mathrm{m}^{2}$ ). LeCren and Lowe-McConnell (1980) concluded that the daily integral primary production of the 50 IBP lakes was uncorrelated with either latitude or altitude; however, the less productive lakes tended to have a maximum daily integral primary production of less than $267 \mathrm{mg} \mathrm{C} / \mathrm{m}^{2}\left(800 \mathrm{mg} \mathrm{O}_{2} / \mathrm{m}^{2}\right)$.

Several subarctic Alaskan lakes were available for comparison with Big Lake's rates of daily integral primary production. Goldman (1960) studied primary production in Brooks and Naknek Lakes on the Alaska Peninsula (58$59^{\circ}$ N., $154-157^{\circ}$ W.). During June to September 1959 , he found that the range in daily integral primary production, in milligrams of carbon per square meter, in Naknek Lake was 139.4 to 224.8 , and it was 88.1 to 219.1 in Brooks Lake. The maximum daily rate of integral primary production measured by Barsdate and Alexander (1971) for Round Lake in the Tangle Lakes system $\left(63^{\circ} \mathrm{N} ., 146^{\circ} \mathrm{W}\right.$.) was $635 \mathrm{mg} \mathrm{C} / \mathrm{m}^{2}$ during September 1966 . The study of Harding Lake by LaPerriere and others (1978) showed that daily integral primary production during 1975 ranged from 1.0 to $447.2 \mathrm{mg} \mathrm{C} / \mathrm{m}^{2}$. The lowest rates occurred in November and December, whereas the highest rate was measured in late May. More recently, Woods and Rowe (1986) have measured primary production in Horseshoe Lake $\left(61^{\circ}\right.$ N., $150^{\circ}$ W.) near Anchorage. This small, shallow lake had a range of daily integral primary production from 44.2 to $104.5 \mathrm{mg} \mathrm{C} / \mathrm{m}^{2}$ during June through August 1985 . These five subarctic Alaskan lakes had an overall range from 1.0 to $635 \mathrm{mg} \mathrm{C} / \mathrm{m}^{2}$ for daily integral primary production, which encompasses the range measured at Big Lake in 1984.

In comparing the daily integral primary production of several lakes, one needs to keep in mind that this variable is affected by euphotic-zone depth. This effect can be accounted for by dividing daily integral primary production by euphotic-zone depth to yield the average daily rate of primary production within the euphotic zone. This calculation was applied to the maximum daily rates of integral primary production that were measured in the following six Alaskan lakes:

$\begin{array}{llll}\text { Big Lake } & 298.4 \mathrm{mg} \mathrm{C} / \mathrm{m}^{2} \div 14.0 \mathrm{~m} & =21.3 \mathrm{mg} \mathrm{C} / \mathrm{m}^{3} \\ \text { Brooks Lake } & 219.1 & \div 45.0 & =4.9 \\ \text { Harding Lake } & 447.2 & \div 25.0 & =17.9 \\ \text { Horseshoe Lake } & 104.5 & \div 5.5 & =19.0 \\ \text { Naknek Lake } & 224.8 & \div 16.0 & =14.0 \\ \text { Round Lake } & 635.0 & \div 5.3 & =119.8\end{array}$

Big, Harding, Horseshoe, and Naknek Lakes had similar average rates of primary production. Brooks Lake was much less productive on a volumetric basis, whereas Round Lake was substantially more productive than the other five lakes. 


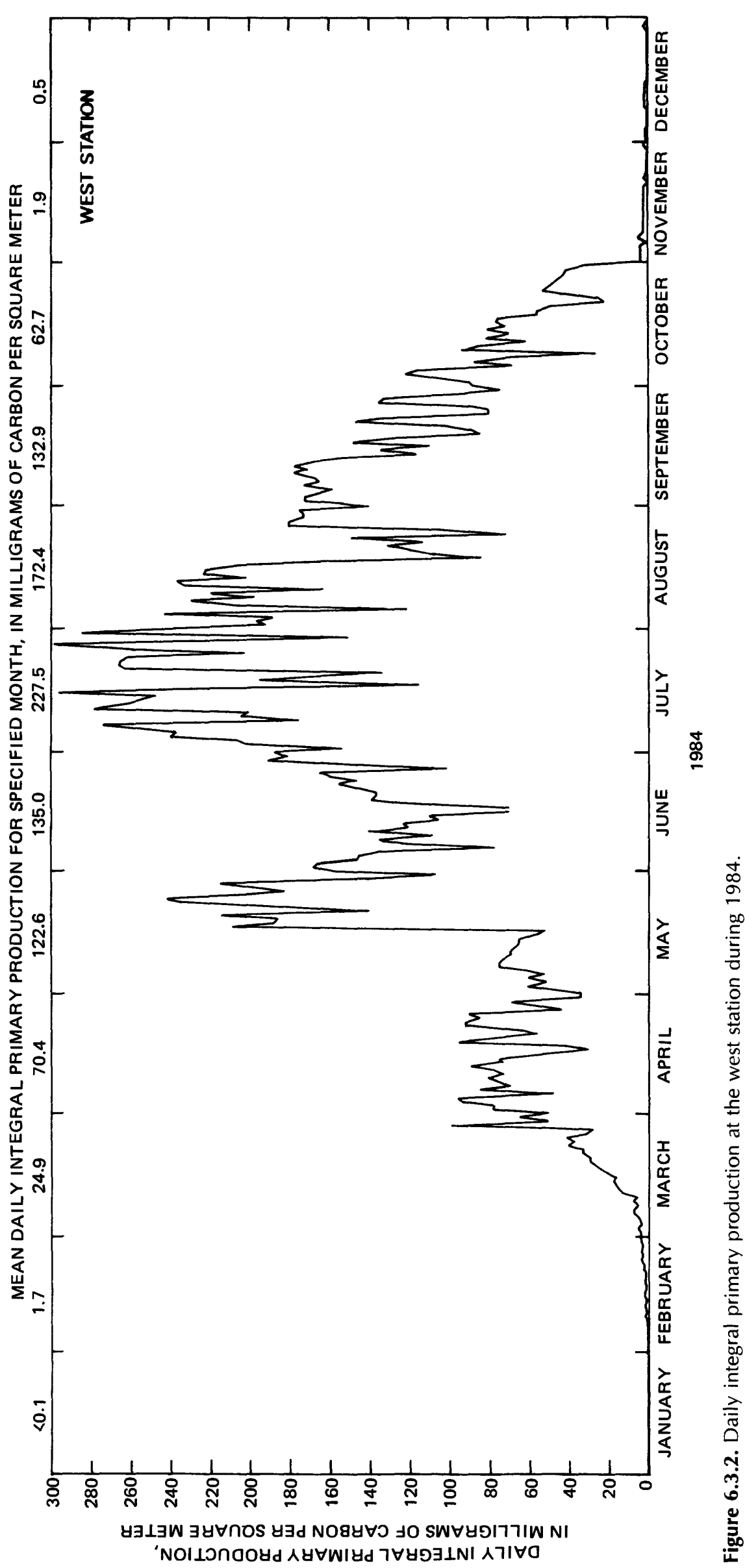




\title{
6.0 PRIMARY PRODUCTION OF PHYTOPLANKTON-Continued
}

\author{
6.4 Depth Distribution of Photoassimilation
}

\section{Photoinhibition Reduced Photoassimilation in the Upper Water Column on Sunny Summer Days}

Daily photoassimilation, in milligrams of carbon per cubic meter, on the winter solstice was less than 2.0, whereas on the summer solstice it reached 14.3.

The preceding section discussed the average primary production of the euphotic zone and integral primary production, both of which are useful variables for among-lake comparisons of primary production. Both mask the variation of photoassimilation with depth that is commonly observed in water-column profiles of primary production. The primary-production model discussed in section 2.4 of this report generated water-column profiles of photoassimilation for each day of 1984 for both primary limnological stations at Big Lake.

Representative water-column profiles of photoassimilation are shown in figure 6.4 to illustrate differences between winter and summer primary production. On December 21 , the winter solstice, only $0.6 \mathrm{E} / \mathrm{m}^{2}$ of PAR was recorded for solar irradiance. On this date, the east station had an ice cover of $0.5 \mathrm{~m}$, which was overlain by $0.05 \mathrm{~m}$ of snow; the euphotic zone was $5.5 \mathrm{~m}$ deep. Curve I shows that on December 21, daily photoassimilation was less than $2 \mathrm{mg} \mathrm{C} / \mathrm{m}^{3}$ and the daily integral primary production was $3.5 \mathrm{mg} \mathrm{C} / \mathrm{m}^{2}$. Numerous other winter days had photoassimilation rates less than $0.2 \mathrm{mg} \mathrm{C} / \mathrm{m}^{3}$ in their most productive layers.

In contrast to these low, under-ice rates of photoassimilation, curve II shows that the west station on April 18 had photoassimilation rates as high as $21 \mathrm{mg} \mathrm{C} / \mathrm{m}^{3}$. The ice cover was $0.6 \mathrm{~m}$ thick, but the daily input of solar irradiance was much higher than on the winter solstice. The result was a deeper euphotic zone and a daily rate of integral primary production that was 27 times larger than that on the winter solstice.

Curves III-V show the dates on which the lowest and highest daily rates of integral primary production were measured during the open-water season. On June 15, the east station (curve III) produced $65.5 \mathrm{mg} \mathrm{C} / \mathrm{m}^{2}$ in its 10.8 $\mathrm{m}$-deep euphotic zone, and daily photoassimilation rates were less than $13 \mathrm{mg} \mathrm{C} / \mathrm{m}^{3}$. Solar irradiance on this overcast day was only $15.0 \mathrm{E} / \mathrm{m}^{2}$. Six days later, on the summer solstice, the daily solar irradiance was $55.6 \mathrm{E} / \mathrm{m}^{2}$, and daily integral primary production reached $145.4 \mathrm{mg} \mathrm{C} / \mathrm{m}^{2}$ in the 13.0-m-deep euphotic zone (curve IV). Photoassimilation rates on June 21 peaked at $14.3 \mathrm{mg} \mathrm{C} / \mathrm{m}^{3}$ and thus were not substantially different from the peak rates measured on June 15. Curve V illustrates the day (July 27) on which the maximum daily rate of integral primary production was measured. The euphotic-zone depth was $14.5 \mathrm{~m}$, and the solar-irradiance input was $39.2 \mathrm{E} / \mathrm{m}^{2}$. Daily photoassimilation rates reached $33.9 \mathrm{mg} \mathrm{C} / \mathrm{m}^{3}$ at a depth of $6 \mathrm{~m}$, whereas at the $1-\mathrm{m}$ depth, photoassimilation declined to $25.4 \mathrm{mg} \mathrm{C} / \mathrm{m}^{3}$. Curve IV also revealed a similar reduction in the upper euphotic zone. This reduction in photoassimilation is commonly observed near a lake's surface on sunny days and is caused by photoinhibition of photosynthesis by supra-optimal amounts of PAR (Harris, 1978; Reynolds, 1984). 
PHOTOASSIMILATION, IN MILLIGRAMS OF CARBON PER CUBIC METER PER DAY

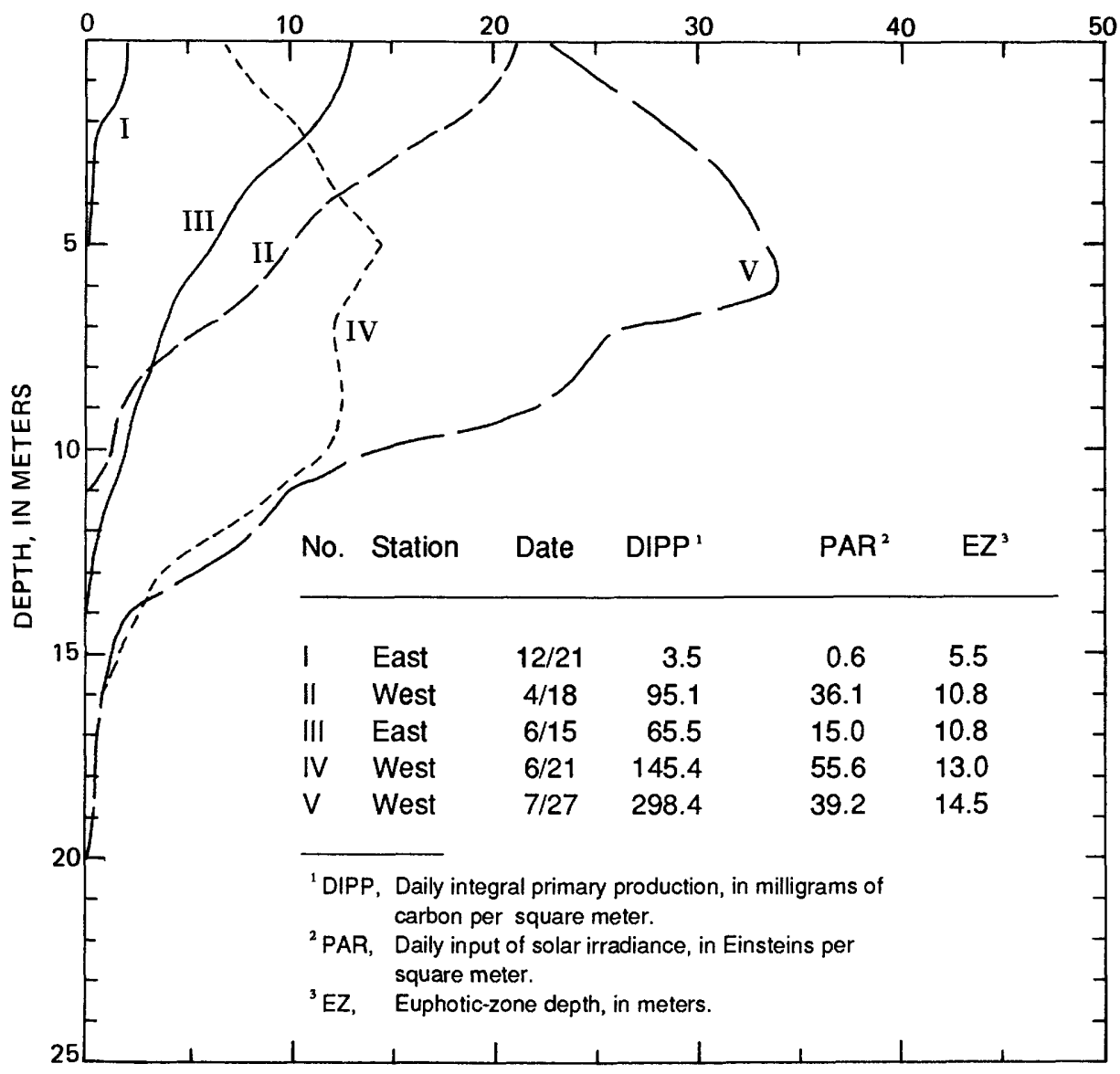

Figure 6.4. Variation of photoassimilation with depth on five sampling dates in 1984 . 


\title{
7.0 TROPHIC STATE
}

\subsection{Classification Systems}

\section{Trophic State of Big Lake Was Determined Using a Quantitative Classification System That Included Physical, Chemical, and Biological Variables}

\begin{abstract}
The trophic state of a lake may be qualitatively described, but more quantitative trophicstate classification systems are normally used to determine where a lake fits in the continuum from oligotrophic to eutrophic.
\end{abstract}

A major objective of the limnological study of Big Lake was to determine the lake's current trophic state. As commonly used, the term "trophic state" refers to the nutrient status of a water body and covers a continuum from nutrient poor to nutrient rich. For ease of categorization, three trophic states are commonly defined: oligotrophic, or nutrient poor; eutrophic, or nutrient rich; and mesotrophic, a middle ground between oligotrophic and eutrophic. Some qualitative descriptions of oligotrophic and eutrophic lakes are listed in table 7.1.1.

The trophic state of a lake is normally determined from a more quantitative classification system than that shown in table 7.1.1. Numerous variables have been employed as the basis for trophic-state classification. Although no universally accepted classification system is currently available, variables such as secchi-disc transparency and concentrations of total phosphorus and chlorophyll- $a$ are frequently used. A trophic-state classification system developed by the Organization for Eco- nomic Development and Cooperation (Ryding and Rast, 1989) was used to classify the trophic state of Big Lake. The four limnological variables listed in table 7.1.2 (concentrations of total phosphorus, total nitrogen, chlorophyll- $a$, and secchi-disc transparency) were statistically analyzed by the Organization for Economic Development and Cooperation (1982) to aid in development of an open-boundary trophic-state classification system. This approach compensates for the overlap in trophicstate classification that commonly occurs with fixedboundary trophic-state classification systems. Under the open-boundary concept, a water body is considered to be correctly classified if no more than one of the limnological variables deviates from its geometric mean by more than two standard deviations. The following section of this report compares the annual mean values of total phosphorus, total nitrogen, chlorophyll- $a$, and secchidisc transparency in Big Lake during 1983 and 1984 with the criteria listed in table 7.1.2. 
Table 7.1.1. Generalized limnological characteristics of oligotrophic and eutrophic lakes

\begin{tabular}{lll}
\hline Limnological characteristic & Oligotrophic & Eutrophic \\
\hline Mean depth & Commonly deep & Commonly shallow \\
Hypolimnion: Epilimnion & $>1$ & $<1$ \\
Transparency & High & Low \\
Organic matter & Low & High \\
Hypolimnetic dissolved- & High & Low or absent \\
$\quad$ throughout & during strati- \\
the year & fication \\
Nutrient concentrations & Low & High \\
Release rate of nutrients & Low & High \\
from bottom sediments & & High \\
Primary production & Low & Moderate \\
Algal species diversity & High & High \\
Algal biomass & Low & Frequent \\
Occurrence of algal blooms & Rare & High \\
Percentage occurrence of green & Low & \\
and (or) blue-green algae & & High \\
Macrophyte abundance & Low & \\
\hline
\end{tabular}

Table 7.1.2. Trophic-state classification based on open-boundary values for four limnological variables

[Modified from Ryding and Rast (1989); m, meter; $\mu \mathrm{g} / \mathrm{L}$, microgram per liter]

\begin{tabular}{|c|c|c|c|c|}
\hline Limnological v & riable' & Oligotrophic & Mesotrophic & Eutrophic \\
\hline $\begin{array}{l}\text { Total } \\
\text { phosphorus } \\
(\mu g / L)\end{array}$ & $\begin{array}{c}\bar{x} \\
\bar{x} \pm 1 \mathrm{SD} \\
\bar{x} \pm 2 \mathrm{SD}\end{array}$ & $\begin{array}{c}8.0 \\
4.8-13.3 \\
2.9-22.1\end{array}$ & $\begin{array}{c}26.7 \\
14.5-49.0 \\
7.9-90.8\end{array}$ & $\begin{array}{c}84.4 \\
48.0-189.0 \\
16.8-424.0\end{array}$ \\
\hline $\begin{array}{l}\text { Total nitrogen } \\
(\mu g / L)\end{array}$ & $\begin{array}{c}\bar{x} \\
\bar{x} \pm 1 \mathrm{SD} \\
\bar{x} \pm 2 \mathrm{SD}\end{array}$ & $\begin{array}{c}661 \\
371-1,180 \\
208-2,103\end{array}$ & $\begin{array}{c}753 \\
485-1,170 \\
313-1,816\end{array}$ & $\begin{array}{c}1,875 \\
861-4,081 \\
395-8,913\end{array}$ \\
\hline $\begin{array}{l}\text { Chlorophyll-a } \\
(\mu \mathrm{g} / \mathrm{L})\end{array}$ & $\begin{array}{c}\bar{x} \\
\bar{x} \pm 1 \mathrm{SD} \\
\bar{x} \pm 2 \mathrm{SD}\end{array}$ & $\begin{array}{c}1.7 \\
0.8-3.4 \\
0.4-7.1\end{array}$ & $\begin{array}{l}4.7 \\
3.0-7.4 \\
1.9-11.6\end{array}$ & $\begin{array}{l}14.3 \\
6.7-31.0 \\
3.1-66.0\end{array}$ \\
\hline $\begin{array}{l}\text { Secchi-disc } \\
\text { depth (m) }\end{array}$ & $\begin{array}{c}\bar{x} \\
\bar{x} \pm 1 \mathrm{SD} \\
\bar{x} \pm 2 \mathrm{SD}\end{array}$ & $\begin{array}{c}9.9 \\
5.9-16.5 \\
3.6-27.5\end{array}$ & $\begin{array}{c}4.2 \\
2.4-7.4 \\
1.4-13.0\end{array}$ & $\begin{array}{c}2.4 \\
1.5-4.0 \\
0.9-6.7\end{array}$ \\
\hline
\end{tabular}

'Annual geometric-mean values and standard deviations (SD). 


\subsection{TROPHIC STATE-Continued}

7.2 Trophic State of Big Lake, 1983-84

\section{Big Lake Was Oligotrophic During 1983-84}

Big Lake was judged to be oligotrophic in 1983-84 on the basis of its secchi-disc transparency and its concentrations of total phosphorus, total nitrogen, and chlorophyll-a. The low dissolved-oxygen concentrations in its hypolimnion were, however, uncharacteristic of oligotrophic lakes.

The annual mean values of total phosphorus, total nitrogen, chlorophyll- $a$, and secchi-disc transparency at the east and west stations during 1983 and 1984 were computed (table 7.2) to permit comparison with the openboundary trophic-state classification listed in table 7.1.2. The trophic state of Big Lake was judged to be oligotrophic in 1983-84, on the basis of the overall mean values for each of the four limnological variables (table 7.2). Annual mean concentrations of total phosphorus and total nitrogen indicated that both stations were oligotrophic in 1983-84. The west station was ranked as oligotrophic in both years on the basis of its secchi-disc transparency and concentration of chlorophyll- $a$. Secchi-disc transparency was within the mesotrophic range for the east station in both years. Chlorophyll- $a$ concentrations at the east station were mesotrophic in 1983 and oligotrophic in 1984. The mesotrophic ranking for 1983 was due largely to the high concentrations of chlorophyll- $a$ found in the deeplying chlorophyll maxima at the east station. The oligotrophic designation for Big Lake is also supported by the lake's mean daily integral primary production of $81.1 \mathrm{mg}$ $\mathrm{C} / \mathrm{m}^{2}$, which is within the range of 50 to $300 \mathrm{mg} \mathrm{C} / \mathrm{m}^{2}$ cited by Wetzel (1975) as characteristic of oligotrophic lakes.

The low dissolved-oxygen concentrations in Big Lake's hypolimnion during summer stratification are uncharacteristic of oligotrophic lakes in general. Several other south-central Alaskan lakes were reported by Woods (1985) to also experience severe depletion of hypolimnetic dissolved oxygen during summer stratification, even though they were considered oligotrophic by virtue of their secchi-disc transparencies and chlorophyll- $a$ concentrations. The low dissolved-oxygen concentrations in the hypolimnia of these lakes and Big Lake result from a combination of limnological and meteorological conditions. The lakes are covered with ice and snow for about 7 months, from mid-October to late May. While ice covered, the lakes develop hypolimnetic dissolved-oxygen deficits in response to a lack of atmospheric reaeration and the consumption of dissolved oxygen by various biochemical and geochemical processes within the water column and at the lake's bottom. The development of the wintertime dissolved-oxygen deficit may be enhanced by an incomplete autumn circulation such as Woods (1985) reported for four south-central Alaskan lakes he examined during 1982-83. By late May, when the ice and snow cover has melted (iceout) and the lakes are ready for spring circulation, these lakes receive insolation for about $18 \mathrm{hr}$ per day, which is characteristic at $61^{\circ} \mathrm{N}$. latitude in late May (Watson and others, 1971). If the days immediately following iceout are sunny and winds are weak, thermal stratification may develop rapidly and full-depth reaeration of the hypolimnion may not occur. This situation occurred in Big Lake in 1983 and 1984; thus, the hypolimnion was undersaturated with dissolved oxygen at the start of summer stratification. Strong thermal stratification through the summer effectively blocked atmospheric reaeration of the hypolimnion and produced low dissolved-oxygen concentrations in the hypolimnion in spite of the lake's oligotrophic nature. 
Table 7.2. Trophic state of Big Lake during 1983-84 based on annual mean values of four limnological variables

[TS, trophic state; O, oligotrophic; M, mesotrophic; m, meter; $\mu \mathrm{g} / \mathrm{L}$, microgram per liter]

\begin{tabular}{|c|c|c|c|c|c|c|c|c|}
\hline \multirow{2}{*}{$\begin{array}{l}\text { Limnological } \\
\text { station and } \\
\text { year }\end{array}$} & \multicolumn{2}{|c|}{$\begin{array}{l}\text { Total } \\
\text { phosphorus } \\
(\mu \mathrm{g} / \mathrm{L})\end{array}$} & \multicolumn{2}{|c|}{$\begin{array}{l}\text { Total } \\
\text { nitrogen } \\
(\mu \mathrm{g} / \mathrm{L})\end{array}$} & \multicolumn{2}{|c|}{$\begin{array}{c}\text { Chlorophyll- } \\
a \\
(\mu \mathrm{g} / \mathrm{L})\end{array}$} & \multicolumn{2}{|c|}{$\begin{array}{l}\text { Secchi-disc } \\
\text { transparency } \\
\text { (m) }\end{array}$} \\
\hline & $\bar{x}^{\prime}$ & TS & $\bar{x}^{\prime}$ & TS & $\bar{x}^{2}$ & TS & $\bar{x}^{3}$ & TS \\
\hline East, 1983 & 9.4 & 0 & 213.5 & o & 3.9 & $\mathbf{M}$ & 5.7 & $\mathbf{M}$ \\
\hline East, 1984 & 8.9 & 0 & 214.1 & O & 2.6 & 0 & 5.5 & $\mathbf{M}$ \\
\hline West, 1983 & 9.4 & 0 & 197.2 & O & 1.8 & 0 & 7.4 & O \\
\hline West, 1984 & 10.2 & 0 & 211.4 & O & 1.7 & O & 6.9 & O \\
\hline $\begin{array}{c}\text { Big Lake, } \\
1983-84\end{array}$ & 9.5 & $\mathrm{O}$ & 208.8 & O & 2.5 & 0 & 6.3 & O \\
\hline
\end{tabular}

${ }^{1}$ Annual mean (geometric) concentration within epilimnion.

${ }^{2}$ Annual mean (geometric) concentration within euphotic zone.

${ }^{3}$ Annual mean (geometric) value. 


\subsection{TROPHIC STATE-Continued}

\subsection{Limnological Effects of Eutrophication}

\section{Major Consequence of Eutrophication Is Increase in Hypolimnetic Dissolved-Oxygen Deficit}

The hypolimnion of a lake may become anoxic as the effects of eutrophication cause a substantial increase in the hypolimnetic dissolved-oxygen deficit. Under anoxic conditions, the hypolimnion may experience increases in concentrations of constituents such as ammonia, hydrogen sulfide, iron, manganese, and phosphorus.

The limnological study reported herein was begun in response to concerns over the potential for cultural eutrophication of Big Lake as a result of rapid residential development and recreational use of the lake. During cultural eutrophication, excessive inputs of nutrients from point and nonpoint sources stimulate a lake's biological production to levels that can degrade water quality and impair some or all of the lake's beneficial uses. As a lake changes from an oligotrophic, through mesotrophic, to eutrophic condition, many of its limnological characteristics may be altered (fig. 7.3).

Two of the most visible effects of cultural eutrophication are increased algal biomass (and chlorophyll concentration) and an increased incidence of algal blooms, both of which reduce water-column transparency. Extensive growths of aquatic macrophytes also may develop in shallow areas. Other important effects that are not readily visible include decreases in the diversity of phytoplankton and benthic flora and fauna, reduction of lake depth due to sedimentation of detrital material, and an increase in the lake's hypolimnetic dissolved-oxygen deficit. When the hypolimnetic dissolved-oxygen deficit becomes severe enough, anoxic conditions develop in the hypolimnion. Under such conditions, the hypolimnion may become enriched in concentrations of constituents such as ammonia, hydrogen sulfide, iron, manganese, and phosphorus. The nitrogen and phosphorus compounds released from the lake sediment under anoxic conditions serve as an internal source of nutrients that can increase the rate of nutrient enrichment in the lake. Data collected in the hypolimnion of Big Lake during 1983-84 showed that under anoxic or near-anoxic conditions, there were substantial increases in hypolimnetic concentrations of ammonia (figs. 4.7.2.1, 4.7.2.2) and orthophosphate (figs. 4.6.2.1, 4.6.2.2). Thus, Big Lake did show one of the major consequences of cultural eutrophication; however, as discussed in the previous section, the hypolimnetic dissolved-oxygen deficit was due in part to limnological and meteorological conditions prevalent in south-central Alaska.

On the basis of the analysis of data collected in this limnological study, Big Lake is classified as oligotrophic. The question that remains is whether the lake will become mesotrophic and then eutrophic in response to nutrient inputs from the various point and nonpoint sources in the drainage basin. In order to quantitatively answer such a question, the application of a nutrient-load/lake-response model would be required. The funds needed to collect the data for a realistic application of such a model were considerably beyond those available for this project. The following section suggests topics that would need to be considered if a nutrient-load/lake-response model were to be applied to Big Lake. 


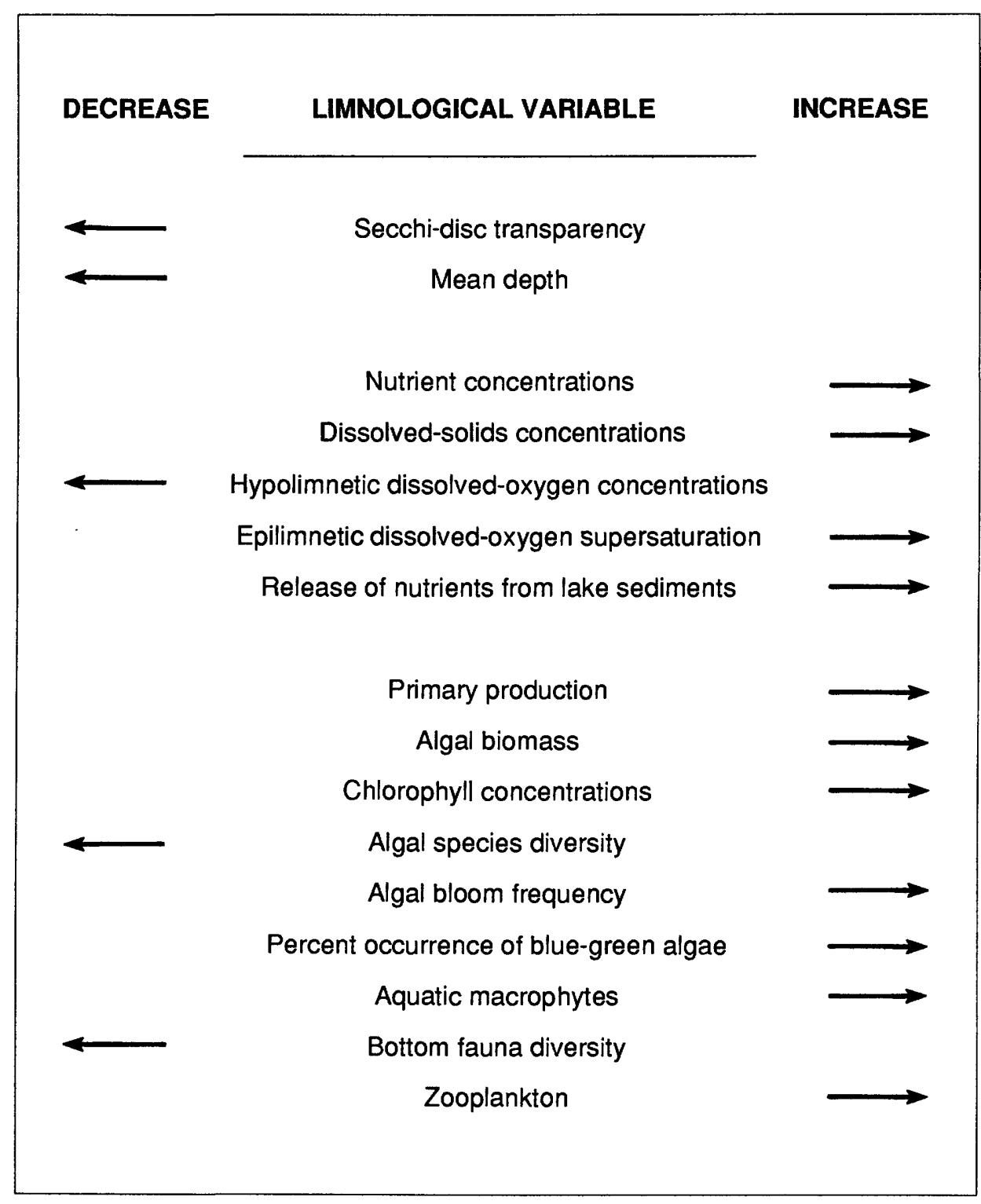

Figure 7.3. Response of selected physical, chemical, and biological variables to eutrophication. 


\title{
7.0 TROPHIC STATE-Continued
}

\subsection{Nutrient-Load/Lake-Response Models}

\section{Nutrient-Load/Lake-Response Models May Be Used to Empirically Assess Effects of Eutrophication on a Lake's Nutrient Concentration}

\begin{abstract}
The concept of nutrient-load/lake-response modeling is applicable to Big Lake, but collection of the necessary hydrologic and nutrient budget data would be a substantial undertaking. The lake's tendency toward nitrogen limitation, not phosphorus limitation, violates an assumption of most phosphorus-based nutrient-load/lake-response models.
\end{abstract}

Numerous models with the goal of predicting the response of a lake to nutrient loadings have been developed for use in lake-eutrophication studies (Vollenweider, 1968; Dillon and Rigler, 1974; Rast and Lee, 1978; Orlob, 1983; Reckhow and Chapra, 1983). These models are commonly called nutrient-load/lake-response models. They calculate an in-lake nutrient concentration by empirically accounting for the effects of flushing and sedimentation on nutrients transported into the lake (fig. 7.4). Two of the terms in the equation in figure 7.4, $L$ and $q_{\mathrm{s}}$, require calculation of hydrologic and nutrient budgets for the lake. A hydrologic budget can be calculated with the equation in figure 7.4, whereas a nutrient budget can be developed by multiplying the terms in the hydrologic-budget equation by their respective nutrient concentrations. The limnological study of Big Lake included data useful for assessing the lakeresponse portion of a model, but computing the hydrologic and nutrient budgets was outside the scope of this project.

Although the conceptual framework of nutrientload/lake-response modeling is applicable to Big Lake, there are several important topics to consider before attempting such an application. First, the data collection efforts required to adequately develop the hydrologic and nutrient budgets are substantial for any application of a nutrientload/lake-response model. They may be even more difficult for Big Lake because of the paucity of reliable data for quantifying variables such as unit runoff coefficients and nutrient export coefficients. Second, many hydrologic budgets have assigned ground water to the residual term because ground water was tacitly assumed to be a minor contributor to the hydrologic budget. However, the groundwater flux of Big Lake may be substantial because the lake is situated in glacial till and may be hydrologically connected to the numerous nearby muskegs, ponds, and lakes (fig. 1.3.1). Third, most nutrient-load/lake-response models have been intended for application to lakes in which algal growth is limited by phosphorus. However, the algal growth in Big Lake tends toward nitrogen, not phosphorus, limitation. Thus, the models are not appropriate for Big Lake if one adheres to their assumptions. 


\section{EQUATION TO COMPUTE IN-LAKE NUTRIENT CONCENTRATION}

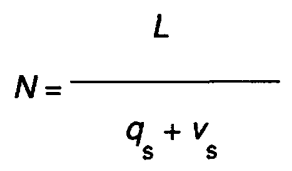

where $N$ is in-lake nutrient concentration, in milligrams per liter;

$L \quad$ is annual areal nutrient loading, in grams per square meter per year;

$q_{\mathrm{s}} \quad$ is areal water loading, in meters per year; and

$v_{s} \quad$ is apparent settling velocity, in meters per year.

EQUATION TO COMPUTE A LAKE'S HYDROLOGIC BUDGET

\begin{tabular}{|c|c|c|}
\hline \multirow[t]{8}{*}{ where } & CS & is change in lake storage; \\
\hline & GSWI & is gaged surface-water inflow; \\
\hline & USWI & is ungaged surface-water inflow; \\
\hline & GWI & is ground-water inflow; \\
\hline & $P$ & is precipitation to the lake surface; \\
\hline & $E$ & is evaporation from the lake surface; \\
\hline & GSWO & is gaged surface-water outflow; and \\
\hline & GWO & is ground-water outflow. \\
\hline
\end{tabular}

Figure 7.4. Equations used to compute a lake's hydrologic budget and an in-lake nutrient concentration. 


\subsection{SUMMARY AND CONCLUSIONS}

\section{Significant Results of Big Lake Limnological Study Summarized}

Big Lake was oligotrophic during 1983 and 1984 but developed severe dissolved-oxygen deficits in the hypolimnion in both years.

The limnological characteristics and trophic state of Big Lake were determined from the results of an intensive 2-year study that was begun in response to concerns over the potential for eutrophication of the lake. Between January 1983 and December 1984, the east and west basins of Big Lake were each visited 36 times to obtain a wide variety of physical, chemical, and biological data. The significant results of those data-collection trips are summarized in figure 8.1.

During 1983 and 1984, Big Lake's trophic state was oligotrophic on the basis of annual mean values for total phosphorus, total nitrogen, chlorophyll- $a$, secchi-disc transparency, and mean daily integral primary production. Big Lake was, however, uncharacteristic of oligotrophic lakes in that a severe dissolved-oxygen deficit developed in the hypolimnion during summer stratification and under winter ice cover. The hypolimnetic dissolved-oxygen deficits developed as a consequence of limnological and meteorological conditions that effectively isolated the hypolimnion from atmospheric reaeration for long periods during the summer and winter. The anoxic conditions that eventually developed near the lake bottom allowed the release of nutrients from the bottom sediments and facilitated ammonification reactions. These processes yielded hypolimnetic concentrations of nitrogen and phosphorus compounds that were much higher than the oligotrophic concentrations measured in the epilimnion.

The results of this study lend credence to the concerns about the potential eutrophication of Big Lake. Although the lake was classed as oligotrophic, the rapid development of the hypolimnetic dissolved-oxygen deficit indicated that the lake's oxygen demand was large relative to the supply rate of oxygen to the hypolimnion. An increase in the amount of oxygen-demanding substances in Big Lake, whether generated within the lake by primary production or delivered to the lake from point and nonpoint sources, likely would worsen the hypolimnetic dissolved-oxygen deficit and thereby increase the release rate of nutrients and other constituents from the lake sediments into the water column. Such increases have the potential to shift the lake's trophic state toward mesotrophic or eutrophic conditions. 
* During May through October, the lake received 76 percent of the annual input of solar irradiance.

- Extinction coefficients ranged from 0.30 to 0.67 per meter.

- Euphotic zone depths ranged from 1 to 15 meters.

- Epilimnion depths ranged from 3.5 to 17 meters.

* The euphotic zone was often deeper than the epilimnion.

- Secchi-disc transparencies ranged from 3.8 to 9.4 meters.

* The maximum water temperature measured was 18.7 degrees Celsius.

- The lake was dimictic and circulated in May and October.

* Thermal stratification was well developed and persistent from June through September.

- The spring circulation failed to completely reaerate the hypolimnion.

Water was of the calcium bicarbonate type.

- Specific conductance ranged from 85 to 161 microsiemens per centimeter at 25 degrees Celsius.

* $\quad \mathrm{pH}$ ranged from 6.2 to 8.0 .

- Dissolved-oxygen concentrations ranged from 0 to 14.7 milligrams per liter; percent saturation ranged from 0 to 124 .

* Total ammonia plus organic nitrogen ranged from 110 to 940 micrograms per liter.

* Dissolved ammonia ranged from $<1$ to 502 micrograms per liter.

* Dissolved nitrite plus nitrate ranged from <1 to 192 micrograms per liter.

- Total phosphorus ranged from 6 to 173 micrograms per liter.

- Dissolved orthophosphate ranged from 1 to 66 micrograms per liter.

* Nitrogen was the nutrient most likely to limit phytoplankton growth during the summer.

- Chlorophyll-a averaged 2.5 micrograms per liter but peaked at 46.5 micrograms per liter.

* The epilimnetic phytoplankton community consisted of 36 genera plus unidentified microalgae.

- Annual integral primary production was 29.6 grams of carbon per square meter; about 90 percent of that was produced during May through October.

* Big Lake was oligotrophic during 1983 and 1984.

Figure 8.1. Summary of significant limnological characteristics of Big Lake during 1983-84. 


\subsection{REFERENCES CITED}

Aleem, A.A., and Samaan, A.A., 1969, Productivity of Lake Mariut, Egypt, Part II. Primary production: International Revue der Gesamten Hydrobiologie und Hydrographie, v. 54, p. 491-527.

Allin, R.W., 1954, Determination of the characteristics of specific fisheries-Anchorage area standard lake and stream surveys: U.S. Fish and Wildlife Service and Alaska Game Commission, Federal Aid in Fish Restoration, Quarterly Report of Progress, Project F-1-R-3, v. 3.

1956, Catch distribution, composition, and size structureSport fishing, Anchorage area: U.S. Fish and Wildlife Service and Alaska Game Commission, Federal Aid in Fish Restoration, Quarterly Report of Progress, Project F-1-R5, v. 5.

Barsdate, R.J., and Alexander, V., 1971, Geochemistry and primary productivity of the Tangle Lakes system-an Alaskan alpine watershed: Arctic and Alpine Research, v. 3, p. 2741.

Canfield, D.E., Bachmann, R.W., and Hoyer, M.V., 1983, Freeze-out of salts in hard-water lakes: Limnology and Oceanography, v. 28 , no. 5, p. 970-977.

Cole, J.J., 1982, Interaction between bacteria and algae in aquatic ecosystems: Annual Review of Ecology and Systematics, v. 13, p. 291-314.

Dearborn, L.L., and Allely, R.D., 1983, Water-well data for the Big Lake area, Anchorage $\mathrm{C}-8 \mathrm{SW}$ quadrangle, Alaska: Alaska Division of Geological and Geophysical Surveys Report of Investigations 83-19, 1 sheet.

Dillon, P.J., and Rigler, F.H., 1974, A test of a simple nutrient budget model predicting the phosphorus concentration in lake water: Journal of the Fisheries Research Board of Canada, v. 31, p. 1771-1778.

Epler, P., 1976, Lots seep Big Lake bacteria: The Anchorage Times, October 28 , p. 14.

Fee, E.J., 1976, The vertical and seasonal distribution of chlorophyll in lakes of the Experimental Lakes Area, northwestern Ontario: Implications for primary production estimates: Limnology and Oceanography, v. 21, no. 6, p. 767-783.

Feulner, A.J., 1971, Water-resources reconnaissance of a part of the Matanuska-Susitna Borough, Alaska: U.S. Geological Survey Hydrologic Investigations Atlas HA-364, 1 sheet.

Goldman, C.R., 1960, Primary productivity and limiting factors in three lakes of the Alaska peninsula: Ecological Monographs, v. 30, p. 207-230.

Harris, G.P., 1978, Photosynthesis, productivity, and growth: The physiological ecology of phytoplankton: Archiv fuer Hydrobiologie, Beiheft, v. 10, p. 1-171.

Hem, J.P., 1985, Study and interpretation of the chemical characteristics of natural water (3rd ed.): U.S. Geological Survey Water-Supply Paper 2254, 264 p.

Hobbie, J.E., 1964, Carbon-14 measurements of primary production in two arctic Alaskan lakes: International Association of Theoretical and Applied Limnology, Proceedings, v. 15, p. 360-364.

Howard, H.H., and Prescott, G.W., 1971, Primary production in Alaskan tundra lakes: American Midland Naturalist, v. 85, no. 1 , p. $108-123$.
Jasper, S., Carmack, E.C., Daley, R.J., Gray, C.B.J., Pharo, C.H., and Weigard, R.C., 1983, Primary productivity in a large, temperate lake with river interflow: Kootenay Lake, British Columbia: Canadian Journal of Fisheries and Aquatic Sciences, v. 40, p. 319-327.

Kalff, J., 1967a, Phytoplankton abundance and primary production rate in two Arctic ponds: Ecology, v. 48, p. 558-565.

1967b, Phytoplankton dynamics in an arctic lake: Journal of the Fisheries Research Board of Canada, v. 24, no. 9, p. 1861-1871.

Karlstrom, T.N.V., 1953, Upper Cook Inlet Region, Alaska, in Péwé, T.L. and others, Multiple glaciation in Alaska: U.S. Geological Survey Circular 289, p. 3-5.

Koenings, J.P., and Kyle, G.B., 1982, Limnology and fisheries investigations at Crescent Lake (1979-1982): Soldotna, Fisheries Rehabilitation, Enhancement, and Development Division, Alaska Department of Fish and Game, 54 p.

Koenings, J.P., Kyle, G.B., Edmundson, J.A., and Edmundson, J.M., 1987, Limnology field and laboratory manual: Methods for assessing aquatic production: Juneau, Alaska Department of Fish and Game, Division of Fisheries Rehabilitation, Enhancement and Development, Report No. 71, 212 p.

LaPerriere, J.D., 1975, Evaluation of the trophic types of several Alaskan lakes by assessment of the benthic fauna: Fairbanks, University of Alaska, Institute of Water Resources, Report IWR-63, 49 p.

LaPerriere, J.D., Tilsworth, T., and Casper, L.A., 1978, Nutrient chemistry of a large, deep lake in subarctic Alaska: U.S. Environmental Protection Agency, EPA-600/3-78-088, $129 \mathrm{p}$.

Lebida, R.C., 1983, Upper Cook Inlet coho salmon habitat evaluation, 1979-1981: Juneau, Alaska Department of Fish and Game, Division of Fisheries Rehabilitation, Enhancement, and Development, Report No. 8, 73 p.

LeCren, E.D., and Lowe-McConnell, R.H., 1980, The functioning of freshwater ecosystems: Cambridge, Cambridge University Press, 588 p.

Organization for Economic Development and Cooperation, 1982, Eutrophication of waters. Monitoring, assessment, and control. Final report: Organization for Economic Development and Cooperation Cooperative Programme on Monitoring of Inland Waters (Eutrophication Control), Environmental Directorate, Paris, 154 p.

Orlob, G.T., ed., 1983, Mathematical modeling of water quality: Streams, lakes and reservoirs: Chichester, John Wiley, 518 p.

Pick, F.R., Nalewajko, C., and Lean, D.R.S., 1984, The origin of a metalimnetic chrysophyte peak: Limnology and Oceanography, v. 29 , no. 1 , p. 125-134.

Prescott, G.W., 1970, How to know the freshwater algae: Dubuque, Iowa, W.C. Brown Co., 348 p.

Priscu, J.C., and Goldman, C.R., 1983, Seasonal dynamics of the deep-chlorophyll maximum in Castle Lake, California: Canadian Journal of Fisheries and Aquatic Sciences, v. 40, no. 2, p. 208-214.

Rast, W., and Lee, G.F., 1978, Summary analysis of the North American (U.S. portions) OECD eutrophication project: Nutrient loading-lake response relationships and trophic state indices: U.S. Environmental Protection Agency, EPA600/3-78-008, $455 \mathrm{p}$. 
Rast, W., ed., 1981, International workshop on the control of eutrophication: International Institute for Applied System Analysis, Laxenburg, Austria, October 1981, 107 p.

Reckhow, K.H., and Chapra, S.C., 1983, Engineering approaches for lake management: Volume 1-Data analysis and empirical modeling: Boston, Butterworth, $340 \mathrm{p}$.

Reynolds, C.S., 1984, The ecology of freshwater phytoplankton: Cambridge, Cambridge University Press, 384 p.

Rheinheimer, G., 1974, Aquatic microbiology: New York, John Wiley, $184 \mathrm{p}$.

Rowe, T.G., 1987, Seasonal variation of photosynthetically active radiation in Big Lake, south-central Alaska, in Huntsinger, R.G., technical chairman, Water quality in the great land-Alaska's challenge: Proceedings, American Water Resources Association, Water Research Center, Institute of Northern Engineering, University of Alaska, Fairbanks, Report IWR-109, p. 95-104.

Ryding, S.O., and Rast, W., 1989, Control of eutrophication of lakes and reservoirs, v. 1 in Man and the Biosphere (Paris, UNESCO): Cambridge, Cambridge University Press, 295 p.

Schoephorster, D.B., 1968, Soil survey of Matanuska Valley area, Alaska: Soil Conservation Service, 67 p. + plates.

Shearer, J., 1976, Construction and operation of a portable incubator for phytoplankton primary production studies: Canadian Fisheries and Marine Service Technical Report 638, $22 \mathrm{p}$.

Skougstad, M.W., Fishman, M.J., Friedman, L.C., Erdmann, D.E., and Duncan, S.S., 1979, Methods for determination of inorganic substances in water and fluvial sediments: U.S. Geological Survey Techniques of Water Resources Investigations, book 5, chap. A1, 626 p.

U.S. Department of Agriculture, 1982, Precipitation and water yield, Susitna River basin: Alaska Rivers Cooperative Study, unpublished report, 12 p.

U.S. Department of Commerce, issued annually, Climatological data, Alaska.

U.S. Geological Survey, 1976, Water resources data, Alaska, water year 1975: U.S. Geological Survey Water-Data Report AK-75-1, 410 p.

1984, Water resources data, Alaska, water year 1983: U.S. Geological Survey Water-Data Report AK-83-1, 357 p. 1985, Water resources data, Alaska, water year 1984: U.S.
Geological Survey Water-Data Report AK-84-1, 350 p.

1986, Water resources data, Alaska, water year 1985: U.S. Geological Survey Water-Data Report AK-85-1, 328 p.

U.S. Geological Survey and Alaska Department of Natural Resources, 1984, Alaska water-resources evaluation 5-year plan, 1984-1988: Anchorage, 40 p.

Vollenweider, R.A., 1968, The scientific basis of lake and stream eutrophication, with particular reference to phosphorus and nitrogen as eutrophication factors: Paris, Organization for Economic Cooperation and Development, Technical Report DAS/DSI/68.27, 155 p.

Watson, C.E., Branton, C.I., and Newman, J.E., 1971, Climatic characteristics of selected Alaskan locations: Fairbanks, University of Alaska, Institute of Agricultural Sciences, Technical Bulletin no. 2, 56 p.

Welch, E.B., 1980, Ecological effects of waste water: Cambridge, Cambridge University Press, 337 p.

Wetzel, R.G., 1975, Limnology: Philadelphia, W.B. Saunders Co., 743 p.

Wetzel, R.G., and Likens, G.E., 1979, Limnological analyses: Philadelphia, W.B. Saunders Co., 357 p.

Woods, P.F., 1984, Modeling the integral primary productivity of phytoplankton in Big Lake, south-central Alaska, in Bredthauer, S.R., chairman, Alaska's water-A critical resource, Proceedings: Alaska Section, American Water Resources Association, Institute of Water Resources, University of Alaska, Fairbanks, Report IWR-106, p. 197206.

-1985, Limnology of nine small lakes, Matanuska-Susitna Borough, Alaska and the survival and growth rates of rainbow trout: U.S. Geological Survey Water-Resources Investigations Report 85-4292, 32 p.

1986, Deep-lying chlorophyll maxima in Big Lake: Implications for trophic-state classification in Alaskan lakes: in Kane, D.L., ed., Cold Regions Hydrology Symposium, Fairbanks, Alaska, 1986, Proceedings: Alaska Section, American Water Resources Association, p. 195-200.

Woods, P.F., and Rowe, T.G., 1986, Primary production, chlorophyll, and nutrients in Horseshoe Lake, Point Mackenzie, Alaska: in Kane, D.L., ed., Cold Regions Hydrology Symposium, Fairbanks, Alaska, 1986, Proceedings: Alaska Section, American Water Resources Association, p. 213-220. 
Metric Conversion Factors and Abbreviations

\begin{tabular}{rll}
\hline \multicolumn{1}{r}{ Multiply } & By & To obtain \\
\hline nanometer $(\mathrm{nm})$ & $3.937 \times 10^{-8}$ & inch \\
micrometer $(\mu \mathrm{m})$ & $3.937 \times 10^{-5}$ & inch \\
millimeter $(\mathrm{mm})$ & $3.937 \times 10^{-2}$ & inch \\
centimeter $(\mathrm{cm})$ & 0.3937 & inch \\
meter $(\mathrm{m})$ & 3.281 & foot \\
kilometer $(\mathrm{km})$ & 0.6214 & mile \\
square meter $\left(\mathrm{m}^{2}\right)$ & 10.76 & square foot \\
square hectometer $\left(\mathrm{hm}^{2}\right)$ & 2.471 & acre \\
square kilometer $\left(\mathrm{km}^{2}\right)$ & 0.3861 & square mile \\
microliter $(\mu \mathrm{L})$ & $2.642 \times 10^{-7}$ & gallon \\
milliliter $\left(\mathrm{mL}^{2}\right)$ & $2.642 \times 10^{-4}$ & gallon \\
$\operatorname{liter}(\mathrm{L})$ & 0.2642 & gallon \\
cubic hectometer $\left(\mathrm{hm}^{3}\right)$ & 810.7 & acre-foot \\
microgram $(\mu \mathrm{g})$ & $3.527 \times 10^{-8}$ & ounce \\
milligram $\left(\mathrm{mg}^{-1}\right)$ & $3.527 \times 10^{-5}$ & ounce \\
gram $(\mathrm{g})$ & $3.527 \times 10^{-2}$ & ounce \\
milligram per cubic meter $\left(\mathrm{mg} / \mathrm{m}^{3}\right)$ & $3.278 \times 10^{-6}$ & ounce per square foot \\
milligram per square meter $\left(\mathrm{mg} / \mathrm{m}^{2}\right)$ & $3.278 \times 10^{-3}$ & ounce per square foot \\
\hline Tram square meter $\left(\mathrm{g} / \mathrm{m}^{2}\right)$ & $9.989 \times 10^{-7}$ & ounce per cubic foot \\
\hline
\end{tabular}

Temperature in this report is given in degrees Celsius, which can be converted to degrees

Fahrenheit by using the formula: Temp. ${ }^{\circ} \mathrm{F}=1.8 \times$ temp. ${ }^{\circ} \mathrm{C}+32$.

$\mu \mathrm{E} \quad$ microEinstein

E Einstein

$\mathrm{E} / \mathrm{m}^{2} \quad$ Einstein per square meter

$\mathrm{g} \mathrm{C} / \mathrm{m}^{2} \quad$ gram of carbon per square meter

$\mu \mathrm{Ci} / \mathrm{mL} \quad$ microcurie per milliliter

$\mu \mathrm{g} / \mathrm{L} \quad$ microgram per liter

$\mathrm{mg} / \mathrm{L} \quad$ milligram per liter

$\mathrm{mg} \mathrm{C} / \mathrm{m}^{2} \quad$ milligram of carbon per square meter

$\mathrm{mg} \mathrm{O} / \mathrm{m}^{2} \quad$ milligram of oxygen per square meter

$\mathrm{mg} \mathrm{C} / \mathrm{m}^{3} \quad$ milligram of carbon per cubic meter

$\mu \mathrm{S} / \mathrm{cm} \quad$ microsiemen per centimeter at $25^{\circ} \mathrm{C}$

W watt 